\title{
Novel HIV-1 Non-nucleoside Reverse Transcriptase Inhibitor Agents: Optimization of Diarylanilines with High Potency against Wild-Type and Rilpivirine-Resistant E138K Mutant Virus
}

\author{
$\mathrm{Na} \mathrm{Liu}^{\dagger}$, Lei Wei ${ }^{\dagger}$, Li Huang ${ }^{\ddagger}$, Fei Yu§, ${ }^{\S}$, Weifan Zheng ${ }^{\perp}$, Bingjie Qin ${ }^{\dagger}$, Dong-Qin Zhu ${ }^{\dagger}$, Susan \\ L. Morris-Natschke ${ }^{\#}$, Shibo Jiang ${ }^{\S, \|}$, Chin-Ho Chen ${ }^{\ddagger}$, Kuo-Hsiung Lee ${ }^{*}, \#, @$, and Lan Xie ${ }^{*}, \dagger, \#$ \\ †Beijing Institute of Pharmacology \& Toxicology, 27 Tai-Ping Road, Beijing 100850, China \\ ‡Surgical Oncology Research Facility, Duke University Medical Center, Box 2926, Durham, North \\ Carolina 27710, United States \\ §Key Laboratory of Medical Molecular Virology of Ministries of Education and Health, Shanghai \\ Medical College and Institute of Medical Microbiology, Fudan University, Shanghai 200032, China \\ "Lindsley F. Kimball Research Institute, New York Blood Center, New York, New York 10065, \\ United States \\ ${ }^{\perp}$ Department of Pharmaceutical Sciences \& BRITE Institute, North Carolina Central University, \\ Durham, North Carolina 27707, United States \\ \#Natural Products Research Laboratories, UNC Eshelman School of Pharmacy, University of \\ North Carolina, Chapel Hill, North Carolina 27599-7568, United States \\ $@$ Chinese Medicine Research and Development Center, China Medical University and Hospital, \\ Taichung, Taiwan
}

\begin{abstract}
Three series $(\mathbf{6}, \mathbf{1 3}$, and 14) of new diarylaniline (DAAN) analogues were designed, synthesized, and evaluated for anti-HIV potency, especially against the E138K viral strain with a major mutation conferring resistance to the new-generation non-nucleoside reverse transcriptase inhibitor drug rilpivirine (1b). Promising new compounds were then assessed for physicochemical and associated pharmaceutical properties, including aqueous solubility, $\log \mathrm{P}$ value, and metabolic stability, as well as predicted lipophilic parameters of ligand efficiency, ligand lipophilic efficiency, and ligand efficiency-dependent lipophilicity indices, which are associated with ADME
\end{abstract}

\footnotetext{
"Corresponding Authors Phone: + 1-919-962-0066. Fax: + 1-919-966-3893. khlee@ unc.edu. "Phone and fax: + 86-10-66931690. lanxie4@gmail.com. ASSOCIATED CONTENT

Supporting Information

The Supporting Information is available free of charge on the ACS Publications website at DOI: 10.1021/acs.jmedchem.5b01827.

HPLC purity and HRMS data for target compounds, ${ }^{1} \mathrm{H}$ and ${ }^{13} \mathrm{C}$ NMR spectra of representative compounds, and additional modeling pictures, including stereo pictures for Figure 3 (PDF)

Molecular formula strings. $\mathrm{EC}_{50}$ values and their standard deviation, $\mathrm{CC}_{50}$ values, $\mathrm{FC}$ (fold Change), and SI values for target compounds 6a-p, 13c-d, and 14c-d (CSV)

AUTHOR INFORMATION

Notes

The authors declare no competing financial interest.
} 
property profiles. Compounds $\mathbf{6 a}, \mathbf{1 4 c}$, and $\mathbf{1 4 d}$ showed high potency against the $\mathbf{1 b}$-resistant E138K mutated viral strain as well as good balance between anti-HIV-1 activity and desirable druglike properties. From the perspective of optimizing future NNRTI compounds as clinical trial candidates, computational modeling results provided valuable information about how the $\mathrm{R}^{1}$ group might provide greater efficacy against the E138K mutant.

\section{Graphical abstract}
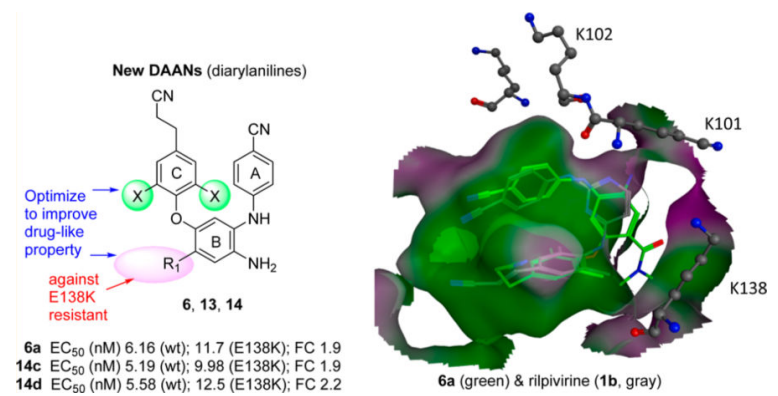

\section{INTRODUCTION}

Because of their high potency and low toxicity, non-nucleoside reverse transcriptase inhibitors (NNRTIs) are used as key drugs in highly active antiretroviral therapy (HAART) ${ }^{1}$ for the treatment of HIV infection and AIDS. However, resistance to some drugs, especially to the early NNRTI drugs nevirapine, delavirdine, and efavirenz, has occurred as a result of rapidly developing mutations of the viral NNRTI binding site. To address this major problem, two next-generation NNRTI drugs, etravirine (TMC125, 1a) ${ }^{2}$ and rilpivirine $\left(\right.$ TMC278, 1b) ${ }^{3}$ (Figure 1), were successfully developed and approved by the U.S. Food and Drug Administration (FDA) in 2008 and 2011, respectively. Compounds 1a and 1b belong to the same diarylpyrimidine (DAPY) family, possess extremely high potency against the wild type and a broad spectrum of mutated NNRTI strains resistant to early NNRTI drugs, ${ }^{4}$ and also present a higher genetic barrier against HIV-1 resistance, ${ }^{5,6}$ most likely resulting from their molecular flexibility. However, because of the high mutation rate of HIV-1 RT and the lack of intrinsic exonucleolytic proofreading activity, new resistance profiles associated with $\mathbf{1 a}$ and $\mathbf{1 b}$ are also being observed in patients. ${ }^{7,8}$ These viral mutations are distinct from each other ${ }^{9}$ as well as distinct from those seen with the early NNRTI drugs. Consequently, novel NNRTI drugs with high potency and different molecular scaffolds are still needed to overcome new drug resistance regimes associated with the new-generation NNRTI anti-HIV drugs $\mathbf{1 a}$ and $\mathbf{1 b}$ and to provide more efficacious therapies and treatment options.

In our prior studies of novel HIV-1 NNRTI agents, we discovered two series of extremely potent anti-HIV NNRTI agents, diarylanilines (DAANs, 2$)^{10}$ and diarylpyridiamines (DAPAs, 3) ${ }^{11,12}$ as shown in Figure 2. The new chemo-type scaffolds have topologic shape and molecular flexibility similar to those of new-generation NNRTI drugs 1a and $\mathbf{1 b}$. The initial leads 2a and 3a exhibited high anti-HIV potency against wild-type HIV-1 replication with low to subnanomolar $\mathrm{EC}_{50}$ values of 3.0 and $0.71 \mathrm{nM}$, respectively, comparable to 
those of $\mathbf{1 a}\left(\mathrm{EC}_{50}=1.5 \mathrm{nM}\right)$ and $\mathbf{1 b}\left(\mathrm{EC}_{50}=0.51 \mathrm{nM}\right)$ in the same assays. ${ }^{10,12}$ However, very low bioavailability $(F \%<3)$ in rats impeded their further development. Subsequently, multiple structural modifications were introduced to identify structure-activity relationship (SAR) and structure-property relationship (SPR) correlations for DAANs and DAPAs as new HIV-1 NNRTI agents. The subsequent leads $\mathbf{2 b}^{13}$ (DAAN) and $\mathbf{3} \mathbf{b}^{14}$ (DAPA) exhibited not only extremely high potency against both wild-type $\left(\mathrm{EC}_{50}\right.$ values of 0.39 and $3.25 \mathrm{nM}$, respectively) and drug-resistant ( $\mathrm{EC}_{50}$ values of 1.8-3.4 and 3.5-6.9 $\mathrm{nM}$, respectively) viral replication but also improved druglike properties. Lead $\mathbf{2 b}$ had a desirable log $\mathrm{P}$ value of 3.68 and a high water solubility of $90 \mu \mathrm{g} / \mathrm{mL}$ at $\mathrm{pH} 2.0$, but its higher metabolism and instability in various solvents prompted continued structural optimization. On the other hand, lead $\mathbf{3 b}$ had high antiresistance potency, with especially low resistance fold changes $(\mathrm{FC}=1.1-2.1)$ for $\mathrm{K} 101 \mathrm{E}$ and $\mathrm{E} 138 \mathrm{~K}$ viral strains resistant to new drugs $\mathbf{1 a}$ and $\mathbf{1 b}$, respectively, compared with that for wild-type NL4-3 virus. This interesting advantage provided the opportunity to explore compounds capable of overcoming the drug resistance associated with $\mathbf{1 a}$ and $\mathbf{1 b}$. Therefore, current optimization efforts have been aimed at discovering new DAANs as potential drug candidates with high antiresistance potency and good balance between antiviral activity and multiple druglike properties. Guided by the prior SAR results, we designed and synthesized three new series $(6,13$, and 14) of DAAN derivatives and evaluated them against HIV-1 wild-type virus and the E138K variant, which contains the most frequent mutation conferring resistance to $\mathbf{1 b},{ }^{15}$ as well as other resistant viral strains. Meanwhile, essential druglike properties and parameters were also assessed and predicted. Herein, we reported our new results and further discussion of SAR and SPR correlations for DAANs and DAPAs.

\section{DESIGN}

As demonstrated in Figure 2, while potent NNRTI DAANs and DAPAs differ by having a benzene and pyridine ring, respectively, as the central ring (B-ring), they also have three of the same known pharmacophores, a p-cyanoaniline moiety (A-ring), the $\mathrm{NH}_{2}$ group on the central B-ring ortho to the A-ring, and a 2,4,6-trisubstituted phenoxy ring (C-ring). With good molecular flexibility and a topologic shape similar to that of $\mathbf{1 b}$, these compounds can adjust their binding conformations to fit the binding site within both wild-type and mutated NNRTI binding pockets. Previous SARs revealed that a linear hydrophobic para- $\mathrm{R}^{2}$ substituent on the $\mathrm{C}$-ring is favorable for potency with the following rank order: cyanoethyl > cyanovinyl > cyano. On the other hand, the $\mathrm{R}^{1}$ substituent on the central B-ring and $\mathrm{X}$ substituents on the $\mathrm{C}$-ring can be modified to improve molecular properties without a loss of potency. Importantly, on the basis of prior molecular docking results, ${ }^{12}$ the $\mathrm{R}^{1}$ substituent on the B-ring is outside of the main NNRTI binding pocket and close to susceptible amino acid E138 on the p51 subdomain of the HIV-1 reverse transcriptase. Thus, modification of this $\mathrm{R}^{1}$ group could provide an interaction between it and the mutated K138, or other preserved amino acid(s) nearby or on the interface between p66 and p51 subdomains, to possibly overcome mutated E138K resistance. Therefore, in the newly designed DAAN analogues $(\mathbf{6}$, $\mathbf{1 3}$, and $\mathbf{1 4}$ series), continued optimizations addressed modifications of the $\mathrm{R}^{1}$ and $\mathrm{X}$ substituents, while the $p$-cyanoethyl substituent $\left(\mathrm{R}^{2}\right)$ on the phenoxy ring $(\mathrm{C} \text {-ring })^{16}$ and $p$ cyanoaniline (A-ring) were maintained (see the formula in Figure 2 ). Because the $\mathrm{R}^{1}$ 
substituent is also associated with molecular physicochemical properties, the current optimization strategy should result in a balance between antiviral potency and multiple druglikeness profiles, which are criteria for advancing a potential drug candidate to the clinic. Additionally, a suitable $\mathrm{R}^{1}$ side chain oriented toward the interface between the HIV-1 RT p66 and p51 subdomains could overcome the drug resistance of E138 K. The series 6 DAAN compounds incorporated various $\mathrm{R}^{1}$ groups with different shapes, volumes, and flexibilities, including amides $(\mathbf{6} \mathbf{a}-\mathbf{d})$, alkylamines $(\mathbf{6 e}-\mathbf{g})$, esters $(\mathbf{6} \mathbf{h}, \mathbf{i})$, carbamates $(\mathbf{6 j})$, alkoxyethers $(\mathbf{6 k}, \mathbf{m})$, and halogens $(\mathbf{6 n}, \mathbf{p})$, to investigate the effects of these groups on potency, antiresistance, and druglike properties. Hetero atoms, such as $\mathrm{O}$ or $\mathrm{N}$, in certain $\mathrm{R}^{1}$ substituents could provide additional interactions with the amino acids on interfaces between p66 and p51 subdomains of the RT enzyme via H-bonds or other forces to increase potency against the E138K mutation and improve molecular physicochemical properties, as well as related druglike properties. In addition, the $\mathrm{X}$ groups on the $\mathrm{C}$-ring were modified for antiresistance and metabolic stability, ${ }^{17}, 18$ resulting in two small sets of new DAANs, the dimethoxy-13 series and the methoxy/bromo-14 series, with either an N-methyl carboxamide or a methyl carboxylate as the $\mathrm{R}^{1}$ substituent. These limited structural optimizations should provide a better understanding of how structure affects potency against HIV-1 wild-type and resistant viral strains, especially for the E138K mutation, as well as other drug properties, with the aim of discovering and developing potential new NNRTI drug candidates.

\section{Chemistry}

As shown in Scheme 1, new compounds $\mathbf{6 a}-\mathbf{c}$ and $\mathbf{6 h}-\mathbf{n}$ were synthesized from $\mathbf{2 m}$, a prior intermediate in the synthesis of DAANs. ${ }^{13}$ The 4-ester group on the central phenyl ring in $\mathbf{2 m}$ was either hydrolyzed under basic conditions or reduced with $\mathrm{LiBH}_{4}$ to the corresponding carboxylic acid (4a) or hydroxymethyl (4b) derivative, respectively. Compound $\mathbf{4 a}$ was then treated with $\mathrm{SOCl}_{2}$ followed by amidation with different amines in THF at $0{ }^{\circ} \mathrm{C}$ to produce the 4 -amido compounds $\mathbf{5 a - c}$. On the other hand, treating $\mathbf{4 b}$ with 2,4,6-trichloro[1,3,5]triazine (TCT) ${ }^{19}$ produced the chloromethyl product $4 \mathbf{c}$, which was reacted immediately with dimethylamine, cyclopropanamine, and 1-methylpiperazine to yield the corresponding 4-alkylaminomethyl compounds 5e-g, respectively. Alternatively, compound $\mathbf{4 b}$ was reacted with acetic anhydride, cyclopropanecarbonyl choloride, and methylcarbamic chloride to yield the corresponding reversed ester compounds $\mathbf{5 h}$ and $\mathbf{5 i}$ and carbamate compound $\mathbf{5 j}$, respectively. Moreover, $\mathbf{4 b}$ was converted to methoxymethyl compound $\mathbf{5} \mathbf{k}$ by reaction with methanol in the presence of $\mathrm{BiCl}_{3}$ at room temperature. Next, the nitro group and the double bond of the $p$-cyanovinyl in intermediates $\mathbf{5 a - c}$ and $\mathbf{5 e - k}$ were reduced simultaneously by catalytic hydrogenation with Pd-C (10\%) in anhydrous ethanol or EtOAc to produce the new DAAN compounds $\mathbf{6 a - c}$ and $\mathbf{6 e - k}$, respectively.

In addition, a new convergent synthetic route was explored to efficiently synthesize additional p-cyanoethylphenoxy-DAANs (Schemes 2 and 3). The C-ring building block 4cyanoethyl-2,6- dimethyl phenol (9a) was prepared from commercial reagent 7a in three steps: benzoylation of the phenol, Wittig reaction of the aldehyde group with diethyl cyanomethylphosphonate, and deprotection by catalytic hydrogenation. Because an electrondonating $p$-cyanoethyl group was present, the coupling of 9a with10a, an 
intermediate synthesized and identified previously, ${ }^{10,13}$ was performed easily to produce 2,4-diaryl nitrobenzene 11a in a high yield of $94 \%$. By conversions similar to those shown in Scheme 1, 11a was converted to the carboxylic acid (11b) and hydroxymethyl (11c) compounds. Compound 11b was converted to the $\mathrm{N}$-substituted carbamoyl product 11d, while 11c was modified successively to the chloromethyl (11e) and ethoxymethyl (11m) nitrodiarylanilines. By Curtius rearrangement, ${ }^{20}$ the 4 -carboxylic acid group of $\mathbf{1 1 b}$ was converted to a 4-amino moiety in $\mathbf{1 1 f}$, which underwent diazonization followed by reaction with cuprous bromide to produce the desired 4-bromo product 11n and the nonbrominated byproduct 11o. Alternatively, coupling of $9 \mathrm{a}$ with $\mathbf{1 0 b}$ was performed under microwave irradiation in DMF in the presence of $\mathrm{K}_{2} \mathrm{CO}_{3}$ at $110^{\circ} \mathrm{C}$ for 10 min to produce 4-chloro compound $11 \mathrm{p}\left(\mathrm{R}_{1}=\mathrm{Cl}\right)$. Finally, nitro compounds $11 \mathrm{~d}$ and $11 \mathrm{~m}$ were reduced conveniently by catalytic hydrogenation to corresponding amino products $6 \mathrm{~d}$ and $6 \mathrm{~m}$, respectively.

However, halogenated nitro compounds $\mathbf{1 1 n}-\mathbf{p}$ were reduced by using the mild reductive reagent $\mathrm{Fe} / \mathrm{NH}_{4} \mathrm{Cl}$ to obtain corresponding amino compounds $\mathbf{6 n}-\mathbf{p}$, respectively. This reaction showed a clear color change from yellow to colorless to identify the reaction's end.

With the same method that was used for the preparation of $9 a$, building blocks 4cyanoethyl-2,6-dimethoxy phenol (9b) and 2-bromo-4-cyanoethyl-6-methoxyphenol (9c) were synthesized from commercially available $\mathbf{7 b}$ and $\mathbf{7 c}$, respectively. As described in Scheme 4, compounds $\mathbf{1 3}(\mathrm{X}=\mathrm{OMe})$ and $\mathbf{1 4}(\mathrm{X}=\mathrm{OMe} / \mathrm{Br})$ were synthesized from compound 10a by coupling with $9 \mathrm{~b}$ or $9 \mathrm{c}$ to produce corresponding esters 13a and 14a followed by amidation with methylamine to yield $\mathbf{1 3 b}$ and $\mathbf{1 4 b}$, respectively. Similar to previous reductions, the 4-nitro in compounds $13 \mathbf{a}$ and $\mathbf{1 3 b}$ was reduced by catalytic hydrogenation, whereas halogenated compounds $14 \mathbf{a}$ and $14 \mathbf{b}$ were reduced with $\mathrm{Fe} / \mathrm{NH}_{4} \mathrm{Cl}$ to generate corresponding DAANs $13 \mathbf{c}, \mathbf{1 3 d}, \mathbf{1 4 c}$, and 14d, respectively. All new target compounds in the $\mathbf{6}, \mathbf{1 3}$, and 14 series were identified by ${ }^{1} \mathrm{H}$ NMR and mass spectrometry data.

\section{RESULTS AND DISCUSSION}

\section{Antiviral Activity and SAR Analysis}

All new DAAN compounds (6, 13, and 14 series) were evaluated against wild-type HIV-1 (NL4-3 and IIIB) and resistant viral strain (E138K, A17, and K101E) replication in TZM-bl (NL4-3 and E138K) and MT-2 (IIIB) cell lines, respectively. Their anti-HIV potency (EC S0, as measured by a luciferase gene expression assay $\left.{ }^{29}\right)$ and cytotoxicity $\left(\mathrm{CC}_{50}\right)$ as well as selective index (SI) data are summarized in Table 1. As expected, with the exception of $\mathbf{6 d}$ and $\mathbf{6 g}$, most of the $\mathbf{6}$ series compounds with various $\mathrm{R}^{1}$ substituents exhibited extremely high potency against wild-type HIV-1 NL4-3 replication in TZM-bl cell lines with low nanomolar $\mathrm{EC}_{50}$ values ranging from 0.53 to $16.0 \mathrm{nM}$. These results were consistent with our previous findings, which indicated that the $\mathrm{R}^{1}$ group can be modified without loss of anti-HIV potency. However, the presence of very bulky $\mathrm{R}^{1}$ groups, e.g., $4-(\mathrm{N}-$ isopropyl)carbamoyl in $\mathbf{6 d}$ and 4 -( $N$-methylpiperazine)-carbamoyl in $\mathbf{6 g}$, impeded molecular antiviral potency, resulting in $\mathrm{EC}_{50}$ values of 72 and $115 \mathrm{nM}$, respectively. We supposed that steric conflict between the bulky $\mathrm{R}^{1}$ groups and the viral amino acid residues within a limited space between the p51 and p66 domains might affect intermolecular affinity and 
binding, leading to reduced potency. Interestingly, the three most potent compounds, $\mathbf{6 c}$ $\left(\mathrm{EC}_{50}=2.00 \mathrm{nM}\right), \mathbf{6}\left(\mathrm{EC}_{50}=0.53 \mathrm{nM}\right)$, and $\mathbf{6 i}\left(\mathrm{EC}_{50}=1.63 \mathrm{nM}\right)$, all contain a cyclopropyl moiety at the end of their $\mathrm{R}^{1}$ side chains; this moiety might have a suitable shape and volume to insert into a cleft between the p66 and p51 subdomains, thereby increasing molecular affinity. When the two $\mathrm{X}$ groups on the $\mathrm{C}$-ring were changed, the dimethoxyDAANs [13c $\left(\mathrm{R}=\mathrm{COOCH}_{3}\right)$ and $\left.\mathbf{1 3 d}\left(\mathrm{R}=\mathrm{CONHCH}_{3}\right)\right]$ were at least 20 -fold less potent than the corresponding bromo/ methoxy-DAANs (14c and $\mathbf{1 4 d}$ ). Indeed, compounds $\mathbf{1 4 c}$ and $\mathbf{1 4 d}$ exhibited similar high potency ( $\mathrm{EC}_{50}$ values of 5.19 and $5.58 \mathrm{nM}$, respectively) against wild-type NL4-3 virus replication and were almost as potent as the prior corresponding dimethyl-DAANs $\mathbf{2 c}\left(\mathrm{EC}_{50}=4.32 \mathrm{nM}\right)$ and $\mathbf{2 d}\left(\mathrm{EC}_{50}=2.73 \mathrm{nM}\right) .{ }^{13}$ Therefore, molecular potency could be maintained by replacing the two methyl groups (X) on the C-ring with methoxy and bromo groups, but not with two methoxy groups. Thus, appropriate $\mathrm{X}$ groups are needed to achieve a favorable binding conformation of the $\mathrm{C}$-ring moiety.

The active DAANs described above $(\mathbf{6}, \mathbf{1 3}$, and $\mathbf{1 4}$ series) were also tested in the MT-2 cell line for inhibition of wild-type HIV-1 IIIB, as well as the multiple-resistant A17 viral strain, replication, and cytotoxicity. The $\mathrm{EC}_{50}$ values against two wild-type viruses (NL4-3 and IIIB) in different cellular assays showed some fluctuation, but similar potency and activity patterns were observed as shown in Table 1. Meanwhile, the low cytotoxicity $\left(\mathrm{CC}_{50}>10\right.$ $\mu \mathrm{M})$ of the compounds resulted in extremely high selective index values ranging from $10^{3}$ to $10^{5}$ (Table 1).

To evaluate our hypothesis concerning a possible link between the $\mathrm{R}^{1}$ substituent of a compound and its effectiveness against NNRTI-resistant virus, active DAAN compounds were tested against the E138K mutated viral strain, which has a major mutation conferring resistance to $\mathbf{1 b}$, and the data are summarized in Table 1. Comparison of the results in the wild-type NL4-3 and drug-resistant E138K assays identified the most promising compounds as $\mathbf{6 a}, \mathbf{6 b}, \mathbf{1 4} \mathbf{c}$, and $\mathbf{1 4 d}$, as indicated by low resistance FCs of 1.9-2.2, which were much better than that of $\mathbf{1 b}(\mathrm{FC}=10)$, lower than those of the other new DAANs, and comparable with those of the prior $\mathbf{2 c}(\mathrm{FC}=1.7)$ and $\mathbf{2 d}(\mathrm{FC}=3.7)$ in the same assay. Notably, $\mathbf{6 a}, \mathbf{6 b}$, $\mathbf{1 4}$, and $\mathbf{1 4 d}$, as well as $\mathbf{2 c}$ and $\mathbf{2 d}$, all contain a carbonyl $(C=O)$ group conjugated with the $\mathrm{B}$-ring, regardless of whether the $\mathrm{R}^{1}$ group is an amide or ester. Thus, this carbonyl group might be important for inhibiting the E138K mutation, possibly because it could interact with the mutated K138 or nearby amino acid(s). Support for this postulate was found from the results for $6 \mathbf{e}, \mathbf{6 f}, \mathbf{6 h}, \mathbf{6 i}$, and $\mathbf{6 k}$, in which the carbonyl group was changed to a methylene $\left(-\mathrm{CH}_{2}-\right)$. Despite their high potency $\left(\mathrm{EC}_{50}=0.53-3.3 \mathrm{nM}\right)$ against wild-type NL4-3 virus, these compounds were much less potent against the E138K viral strain $\left(\mathrm{EC}_{50}>\right.$ 13.3-39 nM), leading to poorer resistance FC values of 9-48 compared with those of $\mathbf{6 a}, \mathbf{6} \mathbf{b}$, $\mathbf{1 4 c}$, and 14d. Thus, the presence of a conjugated carbonyl group in $\mathrm{R}^{1}$ on the B-ring is favorable against the E138K drug $\mathbf{1 b}$ resistance. In addition, representative compounds $\mathbf{6 b}$, 6p, and 2d, which had markedly improved drug-resistant profiles for the E138K mutant, were tested against another 1b-resistant viral strain, K101E. Again, improved drug-resistant profiles with low FC values of 3-4 were seen (Table 1). Moreover, eight active compounds $\left(\mathrm{EC}_{50}<5 \mathrm{nM}\right.$ against IIIB) were further tested in the MT-2 cell line against the multi-NRTI- 
resistant A17 viral strain with mutants K103N and Y181C, the two major mutants from the first-generation NNRTI drugs. Except 6a and 6p, most of them showed high potency against the drug-resistant $\mathrm{A} 17$ viral strain with low nanomolar $\mathrm{EC}_{50}$ values and low $\mathrm{FC}$ values ranging from 0.9 to 14 [lower than that of $\mathbf{1 b}(\mathrm{FC}=18)$ ] compared with wild-type IIIB virus in the same cellular assay, indicating that these compounds are also effective against multidrug resistance to the first-generation NNRTI drugs. Therefore, these results demonstrate that the $\mathrm{R}^{1}$ substituent is the key modification point for overcoming the $\mathbf{1 b}$ drug resistances and other multi-NRTI-resistant strains.

\section{Molecular Modeling}

A computational study was performed to demonstrate how the introduction or modification of a $\mathrm{R}^{1}$ substituent could contribute to overcoming E138K-induced drug resistance to $\mathbf{1 b}$. If DAANs bind to both wild-type and mutant viruses such that the $\mathrm{R}^{1}$ group is oriented toward virus residue 138, then modification of its size, shape, and other properties could afford compounds that would interact with the mutant virus better than drug $\mathbf{1 b}$, which could be measured analytically in terms of lowered FC values. Because of their high wild-type potency (single-digit nanomolar levels) with good FC values (2-fold), compounds 6a and 14d were selected as representatives for the computational study. Again, the latter result is highly desirable for combating resistance in the E138K mutant virus. The compounds were docked computationally to both wild-type RT/1b [Protein Data Bank (PDB) entry 3MEC] ${ }^{21}$ and mutated E138K RT/nevirapine (PDB entry $2 \mathrm{HNY})^{22}$ complex crystal structures. For comparison, drug $\mathbf{1 b}$ was also docked to both the wild-type and mutant structures. The docking protocol is described in the computational section.

As shown in Figure 3, the docking poses of $\mathbf{6 a}$ (green) and $\mathbf{1 b}$ (gray) in both 3MEC (wildtype) and 2HNY (E138K mutant) structures, respectively, displayed similar binding orientations with "U"--like conformational shapes and two characteristic hydrogen bonds formed with the key amino acid K101, consistent with prior results and literature reports on 1b. In both cases, the $\mathrm{R}^{1}$ side chain of $\mathbf{6 a}$ pointed toward the domain space containing viral residue 138. The greater flexibility of K138 could make the mutant virus more tolerant than the wild-type virus toward various $\mathrm{R}^{1}$ side chain substitutions, as reflected by better FC values. Ten of the 14 docking cases were consistent with this observation. Moreover, as seen in the bottom half of Figure 3, the carbonyl group in the $\mathrm{R}^{1}$ substituent of $6 \mathbf{a}$ was oriented toward the amino group in the side chain of K138. Even though a clear interaction between the carbonyl in $\mathrm{R}^{1}$ and the amino group of $\mathrm{K} 138$ was not observed in the current models, additional $\mathrm{H}$-bond(s) with a bridging water molecule could be formed to reach high affinity with the mutant target. The second representative compound $\mathbf{1 4 d}$ provided similar results, and its docking figures can be found in the Supporting Information. Therefore, the current modeling results supported our hypothesis that the $\mathrm{R}^{1}$ substituent is associated with the potency of the NNRTIs against viral mutants with resistance to NNRTIs and should, therefore, help in the further optimization of new drug candidates that can overcome the drug resistance to current NNRTI drugs.

On the other hand, to understand why a small structural change made a significant reduction in potency, we compared the docked models of both less active $13 \mathbf{d}(\mathrm{X}=\mathrm{MeO} / \mathrm{MeO})$ and 
the corresponding active $14 d(\mathrm{X}=\mathrm{MeO} / \mathrm{Br}$ ) into the wild-type structure (3MEC). As shown in Figure 4, the A-ring and B-ring in both molecules superimposed well, but the C-ring was tilted upward in 13d because of the steric effect of the bulkier methoxy group (outside) on this ring. We suppose that the C-ring in 13d is thus forced away from the Y181 or Y188 residue, reducing the molecular affinity for the viral target and then decreasing the potency. However, the C-ring in $\mathbf{1 4 d}$ superimposed completely with that of active compound $\mathbf{6 f}$ [ $\mathrm{X}=$ $\mathrm{Me} / \mathrm{Me}$ (data not shown)], as the bromine atom in $\mathbf{1 4 d}$ is similar in size to the methyl (X) in series 6 . Furthermore, less active $\mathbf{6 g}$ and active $\mathbf{6 f}$ were docked in the wild-type RT crystal structure (3MEC) following the same docking protocol. The bulkier group on $\mathrm{R}^{1}$ in $\mathbf{6 g}$ pushed more against E138, resulting in a minor shift in $\mathbf{6 g}$ 's binding mode compared with that of $\mathbf{6 f}$ (Figure in the Supporting Information). This shift may affect the critical interaction between the C-ring and residues W229, Y181, and Y188, thus providing support for our previous supposition for why $\mathbf{6} \mathbf{g}$ was less potent than $\mathbf{6 f}$.

\section{Druglike Properties and Parameters}

Active DAANs $6 \mathbf{6}-\mathbf{c}, 6 \mathbf{6}, 6 \mathbf{6}, \mathbf{6 h}, \mathbf{6 i}, \mathbf{6 k}, \mathbf{6 n}, \mathbf{1 4 c}$, and $\mathbf{1 4 d}\left(\mathrm{EC}_{50}<10 \mathrm{nM}\right)$ were further assessed for certain physicochemical properties required for potential drug candidates to attain a critical balance between potency and druglike properties. According to methods described previously, ${ }^{13}, 23$ aqueous solubility at $\mathrm{pH} 7.4$ and 2.0, $\log \mathrm{P}$ values, and in vitro metabolic stability were measured, and the results are summarized in Table 2 . Compounds 6e and $6 \mathbf{f}$ with an alkylamine- $\mathrm{R}^{1}$ side chain displayed good molecular solubility at both $\mathrm{pH}$ 2.0 (260 and $276 \mu \mathrm{g} / \mathrm{mL}$, respectively) and pH 7.4 (23.4 and $13.6 \mu \mathrm{g} / \mathrm{mL}$, respectively), typical physiological environments encountered by a drug in stomach and plasma, respectively. However, the carbamoyl-DAANs $6 \mathbf{a}, \mathbf{6 b}, \mathbf{6 c}$, and $\mathbf{1 4 d}$ showed reasonable aqueous solubility $(25.8-141 \mu \mathrm{g} / \mathrm{mL})$ only at $\mathrm{pH} 2.0$, regardless of whether $\mathrm{X}$ is $\mathrm{Me} / \mathrm{Me}$ or $\mathrm{MeO} / \mathrm{Br}$. These results indicated that the increased molecular alkalescence afforded by the $\mathrm{N}$ atom in the $\mathrm{R}^{1}$ substituent of $\mathbf{6 e}$ and $\mathbf{6} \mathbf{f}$ led to improved molecular aqueous solubility, especially in an acidic medium. In contrast, the compounds with oxygen $(\mathrm{O})$ or halogen atoms in the $\mathrm{R}^{1}$ side chain [see $\mathbf{6} \mathbf{h}$ and $\mathbf{6 i}\left(\mathrm{R}^{1}=\mathrm{CH}_{2} \mathrm{OCOR}{ }^{\prime}\right), \mathbf{6 k}\left(\mathrm{R}^{1}=\mathrm{CH}_{2} \mathrm{OMe}\right), \mathbf{6 n}\left(\mathrm{R}^{1}=\right.$ $\mathrm{Br})$, and $\mathbf{1 4 c}\left(\mathrm{R}^{1}=\mathrm{COOMe}\right.$, and $\left.\left.\mathrm{X}=\mathrm{Br} / \mathrm{OMe}\right)\right]$ exhibited lower aqueous solubility ranging from 0.12 to $2.63 \mu \mathrm{g} / \mathrm{mL}$ at both $\mathrm{pH} 2.0$ and 7.4 . In total, the current results indicated the following rank order of aqueous solubility based on $\mathrm{R}_{1}$ side chain: alkylamine > amide > ester and ether groups. Improved molecular aqueous solubility under acidic conditions should enhance oral drug absorbability in the stomach. Along with aqueous solubility, lipophilicity is another important druglike property related to molecular biological potency, as well as absorption, distribution, metabolism, and excretion (ADME) profiles and toxicity risk. As shown in Table 2, except for $\mathbf{6 n}(\log \mathrm{P}>5)$, all of the active compounds tested had desirable $\log \mathrm{P}$ values within a range of $2.51-3.69$ at $\mathrm{pH}$ 7.4. Therefore, insertion of hetero atoms into the $\mathrm{R}^{1}$ substituent served as an effective strategy for decreasing lipophilicity, while maintaining high potency, improving aqueous solubility, and decreasing the high risk of unwanted pharmacology.

Most recently, concepts such as ligand efficiency (LE), ${ }^{24}$ ligand lipophilic efficiency (LLE), ${ }^{25}$ and ligand efficiency-dependent lipophilicity (LELP) ${ }^{26}$ have been proposed and are being applied increasingly in many medicinal chemistry programs to usefully direct 
optimization away from highly lipophilic compounds. Defined as the difference between the negative logarithm of the measured potency $\left(\mathrm{pEC}_{50}\right)$ and $\log \mathrm{P}$, the LLE value is a simple but important index combining in vitro potency and lipophilicity, whereas LELP correlates with ADME properties. Accordingly, lipophilic parameters of the active DAANs were calculated by using experimental $\mathrm{EC}_{50}$ and $\log \mathrm{P}$ values with the formulas cited at the bottom of Table 2. Fortunately, most compounds, including $6 \mathbf{6}, 6 \mathbf{c}, 6 \mathbf{6}, 6 \mathbf{6}, \mathbf{6 h}, \mathbf{6 i}, \mathbf{6 k}, \mathbf{1 4 c}$, and $4 \mathbf{d}$, met acceptable levels for all three ligand lipophilic efficiency indices (LE > 0.3, LLE > 5, LELP $<10),{ }^{27}$ while the remaining compounds in Table 2 did not. The compounds with a low LELP value would most likely have the greatest chance of passing all ADME and safety criteria. Additionally, topological polar surface area ( $t$-PSA) parameters of active compounds were calculated with ChemDraw Ultra 12.0 and met the criterion ${ }^{28}$ of $<140 \AA^{2}$. These property assessment results indicated the postulate that optimization of optimized $\mathrm{R}^{1}$ and X substituents could satisfy the dual goals of maintaining high antiviral potency and improving druglike properties at the same time by adjusting molecular lipophilicity.

Furthermore, the metabolic stability of active compounds was evaluated in a human liver microsome (HLM) assay; $\mathbf{1 b}$ and propranolol were also tested for comparison. As shown in Table 2, $\mathbf{6} \mathbf{h}$ and $\mathbf{6 i}$ were metabolized quite quickly, maintaining only 3.0 and $4.18 \%$, respectively, of the parent compound after incubation for $30 \mathrm{~min}$, with short $t_{1 / 2}$ values of 10.2 and 11.7 min, respectively. It is likely that the benzyl ester in the $\mathrm{R}^{1}$ side chain of both compounds is easily metabolized by enzymatic catalysis. In contrast, the remaining tested compounds maintained $>50 \%$ of the original compound after incubation for $30 \mathrm{~min}$. Among them, compounds $6 \mathbf{e}$ and $\mathbf{6 k}$ showed greater metabolic stability than propranolol, a common reference compound with moderate metabolic stability. Compounds $\mathbf{6 b}, \mathbf{1 4 c}$, and $\mathbf{1 4 d}$ were less stable than propranolol but more stable than $\mathbf{1 b}\left(t_{1 / 2}=116 \mathrm{~min}\right)$. Compounds $\mathbf{6 a}$ and $\mathbf{6 f}$ $\left(t_{1 / 2}=99 \mathrm{~min}\right)$ had stability similar to that of $\mathbf{1 b}$. Compounds $\mathbf{6 c}$ and $\mathbf{6 n}\left(\mathrm{R}^{1}=\mathrm{Br}\right)\left(t_{1 / 2}\right.$ values of 63 and $50 \mathrm{~min}$, respectively) were less stable than $1 \mathrm{~b}$. Notably, both bromo compounds $\mathbf{1 4 c}$ and $\mathbf{1 4 d}(\mathrm{X}=\mathrm{Br} / \mathrm{OMe})$ showed reasonable metabolic stability $\left(t_{1 / 2}=139\right.$ $\mathrm{min}$ ) in the HLM assay, indicating that the halogen $\mathrm{Br}$ is acceptable at the $\mathrm{X}$ position on the $\mathrm{C}$-ring instead of a methyl group. We further postulate that series 14 might have improved drug absorption leading to better oral bioavailability, because the high electronegativity of the introduced bromo atom $(\mathrm{Br})$ could the balance molecular aqueous solubility and lipophilicity.

\section{CONCLUSIONS}

Current structural modification studies of DAANs showed that optimization of the $\mathrm{R}^{1}$ and $\mathrm{X}$ substituent on the central phenyl ring (B-ring) and phenoxy ring (C-ring), respectively, could enhance, or maintain, high potency against wild-type and E138K mutant HIV-1 replication and improve molecular aqueous solubility, lipophilicity, and metabolic stability, thus reaching a good balance between high antiviral potency and multiple druglike properties. On this basis, compounds $\mathbf{6 a}, \mathbf{1 4 c}$, and $\mathbf{1 4 d}$ might be potential drug candidates for further development to address new drug resistance deficiencies. Current SAR study further revealed that (1) a carbonyl group in the $\mathrm{R}^{1}$ substituent conjugated with the central phenyl ring (B-ring) is necessary to combat drug resistance from the E138K mutant, (2) hetero 
atoms $(\mathrm{O}, \mathrm{N}$, or $\mathrm{Br})$ in the $\mathrm{R}^{1}$ substituent favor improved druglike ADME properties, (3) bulky $\mathrm{R}^{1}$ groups should be avoided, and (4) $\mathrm{Br}$ and OMe could replace the two original methyl groups in DAANs, but two methoxy groups (X) on the C-ring led to reduced potency, because a steric effect altered the favorable conformation of the C-ring. Most interestingly, we found that the introduced $\mathrm{R}^{1}$ side chain provided a possibility for overcoming the new drug resistance from E138K, a major HIV-1 viral mutant with resistance to the NNRTI drug $\mathbf{1 b}$. For instance, compounds $\mathbf{6 a}, \mathbf{6 b}, \mathbf{1 4 c}$, and $\mathbf{1 4 d}$ exhibited high potency against the wild type as well as $\mathrm{E} 138 \mathrm{~K}$ mutant (low nanomolar $\mathrm{EC}_{50}$ values) with low resistance FC values of 1.9-2.2, which are much lower than that of $\mathbf{1 b}(\mathrm{FC}=10)$. The modeling study with representative compounds $6 \mathbf{a}$ and $\mathbf{1 4 d}$ provided a rationale supporting the role of an optimized $\mathrm{R}^{1}$ group promoting greater efficacy against the E138K mutant, as well as demonstrating possible modification space between subdomains p66 and p51.

The structural design of these compounds was aimed at overcoming the E138K drugresistant variants, and the current results should help in the development of new NNRTI candidates that can overcome the major drug resistance conferred to the new-generation HIV-1 NNRTI drug $\mathbf{1 b}$, as well as other RT-mutated drug resistances. It is likely that additional structural optimizations may be needed to obtain compounds effective against other less prevalent $\mathbf{1 b}$-resistant variants. Nevertheless, the approach and the results of this study are expected to provide a useful blueprint for further structural optimization against the drug-resistant mutants.

\section{EXPERIMENTAL SECTION}

\section{Chemistry}

Melting points were measured with an RY-1 melting apparatus without correction. Proton nuclear magnetic resonance ( ${ }^{1} \mathrm{H}$ NMR) spectra were measured on a JNM-ECA-400 (400 $\mathrm{MHz}$ ) spectrometer using tetramethylsilane (TMS) as the internal standard. The solvent used was $\mathrm{CDCl}_{3}$ unless otherwise indicated. Mass spectra were recorded on an ABI PerkinElmer Sciex API-150 mass spectrometer with electrospray ionization, and the relative intensity of each ion peak is presented as percent. The purities of target compounds were $₫ 5 \%$, as measured by HPLC analyses, which were performed on an Agilent 1200 HPLC system with a UV detector and an Agilent Eclipse XDB-C18 column ( $150 \mathrm{~mm} \times 4.6 \mathrm{~mm}, 5 \mu \mathrm{m})$, eluting with a mixture of solvents $\mathrm{A}$ and $\mathrm{B}$ under two conditions (acetonitrile/water or $\mathrm{MeOH} /$ water). The microwave reactions were performed on a microwave reactor from Biotage, Inc. Thin-layer chromatography (TLC) and preparative TLC plates used silica gel GF254 (200300 mesh) purchased from Qingdao Haiyang Chemical Co. Medium-pressure column chromatography was performed using a CombiFlash companion purification system. All chemical reagents, NADPH, and solvents were obtained from Beijing Chemical Works or Sigma-Aldrich, Inc. Pooled human liver microsomes (lot no. 20150323H) (protein content of $20 \mathrm{mg} / \mathrm{mL}, 0.5 \mathrm{~mL}$ ) were purchased from iPhase Biosciences Ltd. (Beijing, China). HLM assay data analysis was conducted on an LC-MS system with an ABI PerkinElmer Sciex API-3000 mass spectrometer with electrospray ionization. 
4-Carboxy-N1'-(4'-cyanophenyl)-5-(4" -cyanovinyl-2" ,6" -dimethylphenoxy)-2nitroaniline (4a)-To a solution of $\mathrm{N}^{1}$-( $4^{\prime}$-cyanophenyl)-5-(4" -cyanovinyl-2", 6 " dimethylphenoxy)-4-methoxycarbonyl-2-nitroaniline (2m) $(234 \mathrm{mg}, 0.50 \mathrm{mmol})$ in a THF/ $\mathrm{MeOH}$ solvent $(6: 1, \mathrm{v} / \mathrm{v})$ was added a few drops of aq $\mathrm{NaOH}(1 \mathrm{~N})$, and the mixture was stirred at room temperature for $10 \mathrm{~h}$. The mixture was poured into ice-water, and the $\mathrm{pH}$ was adjusted to 2 with aq $\mathrm{HCl}(2 \mathrm{~N})$. The precipitated solid was collected, washed with water, and dried to afford $204 \mathrm{mg}$ of 4a: 90\% yield; yellow solid; $\mathrm{mp} 260-262{ }^{\circ} \mathrm{C} ;{ }^{1} \mathrm{H}$ NMR $\left(\right.$ DMSO- $\left.d_{6}\right) \delta 2.06\left(6 \mathrm{H}, \mathrm{s}, 2 \times \mathrm{CH}_{3}\right), 5.95(1 \mathrm{H}, \mathrm{s}, \mathrm{ArH}-6), 6.44(1 \mathrm{H}, \mathrm{d}, J=16.4 \mathrm{~Hz},=\mathrm{CH})$, $7.22\left(2 \mathrm{H}, \mathrm{d}, J=8.8 \mathrm{~Hz}, \mathrm{ArH}-2^{\prime}, 6^{\prime}\right), 7.47\left(2 \mathrm{H}, \mathrm{s}, \mathrm{ArH}-3^{\prime \prime}, 5^{\prime \prime}\right), 7.58(1 \mathrm{H}, \mathrm{d}, J=16.4 \mathrm{~Hz}$, $\mathrm{CH}=), 7.65\left(2 \mathrm{H}, \mathrm{d}, J=8.8 \mathrm{~Hz}, \mathrm{ArH}-3^{\prime}, 5^{\prime}\right), 8.72(1 \mathrm{H}, \mathrm{s}, \mathrm{ArH}-3), 9.79(1 \mathrm{H}, \mathrm{s}, \mathrm{NH}), 13.21$ $(1 \mathrm{H}, \mathrm{s}, \mathrm{COOH}) ; \mathrm{MS} \mathrm{m} / z(\%) 453.3$ (M - 1, 45), 409.0 (M - 44, 100).

N1-(4'-Cyanophenyl)-5-(4"-cyanovinyl-2",6"-dimethylphenoxy)-4hydroxymethyl-2-nitroaniline (4b)-To a solution of 3 (234 $\mathrm{mg}, 0.50 \mathrm{mmol})$ in THF (5 $\mathrm{mL}$ ) was added $\mathrm{LiBH}_{4}(36 \mathrm{mg}, 0.16 \mathrm{mmol})$ at $0{ }^{\circ} \mathrm{C}$ while the mixture was being stirred over $30 \mathrm{~min}$. After $\mathrm{MeOH}$ (13 drops) was added dropwise, the mixture was being stirred at room temperature for $1 \mathrm{~h}$. The mixture was poured into ice-water, and the $\mathrm{pH}$ was adjusted to 2-3 with aq $\mathrm{HCl}(5 \%)$. The solid crude product was filtered out and purified by CombiFlash column chromatography (gradient elution, EtOAc/ $\mathrm{CH}_{2} \mathrm{Cl}_{2}, 0$ to $3 \%$ ) to produce $200 \mathrm{mg}$ of 4b: 91\% yield; yellow solid; mp 232-234 ${ }^{\circ} \mathrm{C} ;{ }^{1} \mathrm{H}$ NMR $\delta 2.15\left(6 \mathrm{H}, \mathrm{s}, 2 \times \mathrm{CH}_{3}\right), 4.89(2 \mathrm{H}, \mathrm{s}$, $\left.\mathrm{CH}_{2} \mathrm{O}\right), 5.85(1 \mathrm{H}, \mathrm{d}, J=16.4 \mathrm{~Hz},=\mathrm{CH}), 6.27(1 \mathrm{H}, \mathrm{s}, \mathrm{ArH}-6), 7.05(2 \mathrm{H}, \mathrm{d}, J=8.8 \mathrm{~Hz}$, ArH-2' $\left.6^{\prime}\right), 7.21$ (2H, s, ArH-3", 5") $7.28(1 \mathrm{H}, \mathrm{d}, J=16.4 \mathrm{~Hz}, \mathrm{CH}=), 7.47(2 \mathrm{H}, \mathrm{d}, J=8.8$ Hz, ArH-3',5'), 8.41 (1H, s, ArH-3), 9.70 (1H, s, NH); MS m/z (\%) 439.3 (M - 1, 100).

\section{4-Chloromethyl-N1'-(4'-cyanophenyl)-5-(4"-cyanovinyl-2", 6" - dimethylphenoxy)-2-nitroaniline (4c)-2,4,6-Trichloro [ 1,3,5] triazine (TCT, $627 \mathrm{mg}$,} $3.41 \mathrm{mmol}$ ), soluble in DMF (4 mL), was stirred at room temperature for a few minutes, and a white solid appeared. The mixture was stirred for $1-2 \mathrm{~h}$ and added to a solution of $\mathbf{4 b}$ (1 $\mathrm{g}, 2.27 \mathrm{mmol})$ in $\mathrm{CH}_{2} \mathrm{Cl}_{2}(15 \mathrm{~mL})$ while the mixture was being stirred at room temperature for $4 \mathrm{~h}$ by TLC and was monitored until the reaction reached completion. The organic phase was washed with water, a saturated $\mathrm{NaHCO}_{3}$ solution, water, and brine, successively, and dried over anhydrous $\mathrm{Na}_{2} \mathrm{SO}_{4}$ overnight. After removal of solvent in vacuo, the crude product was purified by flash column chromatography (elution, $\mathrm{CH}_{2} \mathrm{Cl}_{2}$ ) to afford $800 \mathrm{mg}$ of 4c: 77\% yield; yellow solid; mp 237-239 ${ }^{\circ} \mathrm{C} ;{ }^{1} \mathrm{H}$ NMR $\delta 2.17\left(6 \mathrm{H}, \mathrm{s}, 2 \times \mathrm{CH}_{3}\right), 4.77(2 \mathrm{H}, \mathrm{s}$, $\left.\mathrm{CH}_{2} \mathrm{Cl}\right), 5.85(2 \mathrm{H}, \mathrm{d}, J=16.4 \mathrm{~Hz},=\mathrm{CH}), 6.26(1 \mathrm{H}, \mathrm{s}, \mathrm{ArH}-6), 7.06(2 \mathrm{H}, \mathrm{d}, J=8.4 \mathrm{~Hz}$, ArH-2' $\left.6^{\prime}\right), 7.22\left(2 \mathrm{H}, \mathrm{s}, \mathrm{ArH}-3^{\prime \prime}, 5^{\prime \prime}\right), 7.33(1 \mathrm{H}, \mathrm{d}, J=16.4 \mathrm{~Hz}, \mathrm{CH}=), 7.49(2 \mathrm{H}, \mathrm{d}, J=8.4$ $\left.\mathrm{Hz}, \mathrm{ArH}-3^{\prime}, 5^{\prime}\right), 8.41$ (1H, s, ArH-3), 9.77 (1H, s, NH); MS m/z (\%) 481.3 (M + Na, 100).

\section{General Amidation Procedure for the Preparation of 5a-c}

A solution of carboxylic acid compound $4 \mathbf{a}$ in $\mathrm{SOCl}_{2}(10 \mathrm{~mL})$ was heated to reflux for $4 \mathrm{~h}$ and then poured into petroleum ether while the mixture was being stirred. The precipitated solid was collected by filter. The crude aryl chloride was redissolved in THF and an amine reagent (excess) added at $0{ }^{\circ} \mathrm{C}$ while the mixture was being stirred over $30 \mathrm{~min}$. The solvent was removed under reduced pressure, and the residue was purified by flash column 
chromatography (gradient elution, $\mathrm{CH}_{2} \mathrm{Cl}_{2}$ /petroleum ether, 70 to $100 \%$ ) to obtain the amide product.

\section{4-Carboxy-N1 -(4' -cyanophenyl)-5-(4" -cyanovinyl-2",6" -dimethyl- phenoxy)-2-nitroaniline (4a)-To a solution of $\mathrm{N}^{1}$-(4'-cyanophenyl)-5-(4" -} cyanovinyl-2",6"-dimethylphenoxy)-4-methoxycarbonyl-2-nitroaniline (2m) (234 mg, 0.50 $\mathrm{mmol})$ in a THF/MeOH solvent $(6: 1, \mathrm{v} / \mathrm{v})$ was added a few drops of aq $\mathrm{NaOH}(1 \mathrm{~N})$, and the mixture was stirred at room temperature for $10 \mathrm{~h}$. The mixture was poured into ice-water, and the $\mathrm{pH}$ was adjusted to 2 with aq $\mathrm{HCl}(2 \mathrm{~N})$. The precipitated solid was collected, washed with water, and dried to afford $204 \mathrm{mg}$ of 4a: 90\% yield; yellow solid; mp 260$262{ }^{\circ} \mathrm{C} ;{ }^{1} \mathrm{H}$ NMR (DMSO- $\left.d_{6}\right) \delta 2.06\left(6 \mathrm{H}, \mathrm{s}, 2 \times \mathrm{CH}_{3}\right), 5.95(1 \mathrm{H}, \mathrm{s}, \mathrm{ArH}-6), 6.44(1 \mathrm{H}, \mathrm{d}, J=$ $16.4 \mathrm{~Hz},=\mathrm{CH}), 7.22\left(2 \mathrm{H}, \mathrm{d}, J=8.8 \mathrm{~Hz}, \mathrm{ArH}-2^{\prime}, 6^{\prime}\right), 7.47\left(2 \mathrm{H}, \mathrm{s}, \mathrm{ArH}-3^{\prime \prime}, 5^{\prime \prime}\right), 7.58(1 \mathrm{H}, \mathrm{d}$, $J=16.4 \mathrm{~Hz}, \mathrm{CH}=), 7.65\left(2 \mathrm{H}, \mathrm{d}, J=8.8 \mathrm{~Hz}, \mathrm{ArH}-3^{\prime}, 5^{\prime}\right), 8.72(1 \mathrm{H}, \mathrm{s}, \mathrm{ArH}-3), 9.79(1 \mathrm{H}, \mathrm{s}$, $\mathrm{NH}), 13.21$ (1H, s, COOH); MS m/z (\%) 453.3 (M - 1, 45), 409.0 (M - 44, 100).

\section{N1-(4'-Cyanophenyl)-5-(4"-cyanovinyl-2",6"-dimethylphenoxy)-4-} hydroxymethyl-2-nitroaniline (4b)-To a solution of 3 (234 mg, $0.50 \mathrm{mmol})$ in THF (5 $\mathrm{mL}$ ) was added $\mathrm{LiBH}_{4}(36 \mathrm{mg}, 0.16 \mathrm{mmol})$ at $0{ }^{\circ} \mathrm{C}$ while the mixture was being stirred over 30 min. After $\mathrm{MeOH}$ (13 drops) was added dropwise, the mixture was stirred at room temperature for $1 \mathrm{~h}$. The mixture was poured into ice-water, and the $\mathrm{pH}$ was adjusted to 2-3 with aq $\mathrm{HCl}(5 \%)$. The solid crude product was filtered out and purified by CombiFlash column chromatography (gradient elution, EtOAc/ $/ \mathrm{CH}_{2} \mathrm{Cl}_{2}, 0$ to $3 \%$ ) to produce $200 \mathrm{mg}$ of 4b: 91\% yield; yellow solid; mp 232-234 ${ }^{\circ} \mathrm{C} ;{ }^{1} \mathrm{H}$ NMR $\delta 2.15\left(6 \mathrm{H}, \mathrm{s}, 2 \times \mathrm{CH}_{3}\right), 4.89(2 \mathrm{H}$, s, $\left.\mathrm{CH}_{2} \mathrm{O}\right), 5.85(1 \mathrm{H}, \mathrm{d}, J=16.4 \mathrm{~Hz},=\mathrm{CH}), 6.27(1 \mathrm{H}, \mathrm{s}, \mathrm{ArH}-6), 7.05(2 \mathrm{H}, \mathrm{d}, J=8.8 \mathrm{~Hz}$, ArH-2', $\left.6^{\prime}\right), 7.21$ (2H, s, ArH-3" , 5"), $7.28(1 \mathrm{H}, \mathrm{d}, J=16.4 \mathrm{~Hz}, \mathrm{CH}=), 7.47(2 \mathrm{H}, \mathrm{d}, J=8.8$ Hz, ArH-3',5'), 8.41 (1H, s, ArH-3), 9.70 (1H, s, NH); MS m/z (\%) 439.3 (M - 1, 100).

\section{4-Chloromethyl-N1'-(4'-cyanophenyl)-5-(4" -cyanovinyl-2",6"-} dimethylphenoxy)-2-nitroaniline (4c)—2,4,6-Trichloro[ 1,3,5]triazine (TCT, $627 \mathrm{mg}$, $3.41 \mathrm{mmol}$ ), soluble in DMF (4 mL), was stirred at room temperature for a few minutes, and a white solid appeared. The mixture was stirred for $1-2 \mathrm{~h}$ and added to a solution of $4 \mathbf{b}$ ( $1 \mathrm{~g}$, $2.27 \mathrm{mmol})$ in $\mathrm{CH}_{2} \mathrm{Cl}_{2}(15 \mathrm{~mL})$ while the mixture was being stirred at room temperature for $4 \mathrm{~h}$, monitored by TLC until the reaction reached completion. The organic phase was washed with water, a saturated $\mathrm{NaHCO}_{3}$ solution, water, and brine, successively, and dried over anhydrous $\mathrm{Na}_{2} \mathrm{SO}_{4}$ overnight. After removal of solvent in vacuo, the cure product was purified by flash column chromatography (elution, $\mathrm{CH}_{2} \mathrm{Cl}_{2}$ ) to afford $800 \mathrm{mg}$ of $\mathbf{4 c}$ : $77 \%$ yield; yellow solid; mp 237-239 ${ }^{\circ} \mathrm{C} ;{ }^{1} \mathrm{H}$ NMR $\delta 2.17\left(6 \mathrm{H}, \mathrm{s}, 2 \times \mathrm{CH}_{3}\right), 4.77\left(2 \mathrm{H}, \mathrm{s}, \mathrm{CH}_{2} \mathrm{Cl}\right)$, $5.85(2 \mathrm{H}, \mathrm{d}, J=16.4 \mathrm{~Hz},=\mathrm{CH}), 6.26(1 \mathrm{H}, \mathrm{s}, \operatorname{ArH}-6), 7.06\left(2 \mathrm{H}, \mathrm{d}, J=8.4 \mathrm{~Hz}, \mathrm{ArH}-2^{\prime}, 6^{\prime}\right)$, $7.22\left(2 \mathrm{H}, \mathrm{s}, \mathrm{ArH}-3^{\prime \prime}, 5^{\prime \prime}\right), 7.33(1 \mathrm{H}, \mathrm{d}, J=16.4 \mathrm{~Hz}, \mathrm{CH}=), 7.49(2 \mathrm{H}, \mathrm{d}, J=8.4 \mathrm{~Hz}, \mathrm{ArH}-3$ ', 5'), 8.41 (1H, s, ArH-3), 9.77 (1H, s, NH); MS m/z (\%) 481.3 (M + Na, 100).

\section{General Amidation Procedure for Preparation of 5a-c}

A solution of carboxylic acid compound $\mathbf{4 a}$ in $\mathrm{SOCl}_{2}(10 \mathrm{~mL})$ was heated to reflux for $4 \mathrm{~h}$ and then poured into petroleum ether while the mixture was being stirred. The precipitated solid was collected by filter. The crude aryl chloride was redissolved in THF and an amine 
reagent added (excess) at $0{ }^{\circ} \mathrm{C}$ while the mixture was being stirred over $30 \mathrm{~min}$. The solvent was removed under reduced pressure, and the residue was purified by flash column chromatography (gradient elution, $\mathrm{CH}_{2} \mathrm{Cl}_{2}$ /petroleum ether, 70 to $100 \%$ ) to obtain the amide product.

$\mathrm{N}^{1}$-(4" -Cyanophenyl)-5-(4"-cyanovinyl-2", 6" -dimethylphenoxy)-4-(N,Ndimethyl)carbamoyl-2-nitroaniline (5a)—Starting with $\mathbf{4 a}(300 \mathrm{mg}, 0.66 \mathrm{mmol})$ and aqueous dimethylamine (33\%, 5 drops) to afford $249 \mathrm{mg}$ of 5a: $79 \%$ yield; $\mathrm{mp} 122.0$ $124.0{ }^{\circ} \mathrm{C} ;{ }^{1} \mathrm{H}$ NMR $\delta 2.20\left(6 \mathrm{H}, \mathrm{s}, 2 \times \mathrm{CH}_{3}\right), 3.11\left(3 \mathrm{H}, \mathrm{s}, \mathrm{CH}_{3} \mathrm{~N}\right), 3.20\left(3 \mathrm{H}, \mathrm{s}, \mathrm{CH}_{3} \mathrm{~N}\right), 5.84$ $(2 \mathrm{H}, \mathrm{d}, J=16.8 \mathrm{~Hz},=\mathrm{CH}), 6.29(1 \mathrm{H}, \mathrm{s}, \mathrm{ArH}-6), 7.08\left(2 \mathrm{H}, \mathrm{d}, J=8.8 \mathrm{~Hz}, \mathrm{ArH}-2^{\prime}, 6^{\prime}\right), 7.20$ $\left(2 \mathrm{H}, \mathrm{s}, \mathrm{ArH}-3^{\prime \prime}, 5^{\prime \prime}\right), 7.31(1 \mathrm{H}, \mathrm{d}, J=16.8 \mathrm{~Hz}, \mathrm{CH}=), 7.50(2 \mathrm{H}, \mathrm{d}, J=8.8 \mathrm{~Hz}, \mathrm{ArH}-3$ ', 5' $)$, 8.34 (1H, s, ArH-3), 9.75 (1H, s, NH); MS m/z (\%) 482.4 (M + 1, 100).

$\mathrm{N}^{1}$-(4'-Cyanophenyl)-5-(4" -cyanovinyl-2",6" -dimethylphenoxy)-4-(Nethyl)carbamoyl-2-nitroaniline (5b)—Starting with $\mathbf{4 a}(300 \mathrm{mg}, 0.66 \mathrm{mmol})$, and aqueous ethylamine (65-67\%, 3 drops) to afford $130 \mathrm{mg}$ of $\mathbf{5 b}$ : $41 \%$ yield; yellow solid; $\mathrm{mp}$ 208.3-210.0 ${ }^{\circ} \mathrm{C} ;{ }^{1} \mathrm{H}$ NMR $\delta 1.26\left(3 \mathrm{H}, \mathrm{t}, J=7.2 \mathrm{~Hz}, \mathrm{CH}_{3}\right), 2.17\left(6 \mathrm{H}, \mathrm{s}, 2 \times \mathrm{CH}_{3}\right), 3.56(2 \mathrm{H}$, q, $\left.J=7.2 \mathrm{~Hz}, \mathrm{CH}_{2}\right), 5.98(2 \mathrm{H}, \mathrm{d}, J=16.4 \mathrm{~Hz},=\mathrm{CH}), 6.28(1 \mathrm{H}, \mathrm{s}, \operatorname{ArH}-6), 7.06(2 \mathrm{H}, \mathrm{d}, J=$ $\left.8.4 \mathrm{~Hz}, \mathrm{ArH}-2^{\prime}, 6^{\prime}\right), 7.27$ (2H, s, ArH-3" ,5" $), 7.33$ (1H, d, J= $\left.16.4 \mathrm{~Hz}, \mathrm{CH}=\right), 7.49$ (2H, d, $J=8.4$ Hz, ArH-3',5'), 9.28 (1H, s, ArH-3), 9.77 (1H, s, NH); MS m/z (\%) 482.3 (M + 1, 100).

$\mathrm{N}^{1}$-(4'-Cyanophenyl)-5-(4" -cyanovinyl-2", 6" -dimethylphenoxy)-4-(Ncyclopropyl)carbamoyl-2-nitroaniline (5c)—Starting with $4 \mathbf{a}(250 \mathrm{mg}, 0.55 \mathrm{mmol})$ and cyclopropanamine $(114 \mu \mathrm{L})$ to afford $170 \mathrm{mg}$ of 5c: $63 \%$ yield; yellow solid; mp 234$236{ }^{\circ} \mathrm{C} ;{ }^{1} \mathrm{H}$ NMR $\delta 0.60\left(2 \mathrm{H}, \mathrm{m}, \mathrm{CH}_{2}\right), 0.91\left(2 \mathrm{H}, \mathrm{m}, \mathrm{CH}_{2}\right), 2.16\left(6 \mathrm{H}, \mathrm{s}, 2 \times \mathrm{CH}_{3}\right), 2.98(1 \mathrm{H}$, $\mathrm{m}, \mathrm{NCH}), 5.84(2 \mathrm{H}, \mathrm{d}, J=16.4 \mathrm{~Hz},=\mathrm{CH}), 6.27(1 \mathrm{H}, \mathrm{s}, \mathrm{ArH}-6), 7.07(2 \mathrm{H}, \mathrm{d}, J=8.4 \mathrm{~Hz}$, ArH-2', $\left.6^{\prime}\right), 7.25$ (2H, s, ArH-3" $\left.5^{\prime \prime}\right), 7.35$ (1H, d, $\left.J=16.4 \mathrm{~Hz}, \mathrm{CH}=\right), 7.49$ (2H, d, $J=8.4$ Hz, ArH-3',5'), 7.59 (1H, d, J=7.2 Hz, CONH), 9.27 (1H, s, ArH-3), 9.77 (1H, s, NH); MS $\mathrm{m} / \mathrm{z}(\%) 494.3(\mathrm{M}+1,80), 437.3(\mathrm{M}-56,100)$.

$\mathrm{N}^{1}$-(4'-Cyanophenyl)-5-(4" -cyanovinyl-2",6" -dimethylphenoxy)-4-(N,Ndimethylamino)methyl-2-nitroaniline (5e)-A mixture of $4 \mathbf{c}(200 \mathrm{mg}, 0.44 \mathrm{mmol})$ and aqueous dimethylamine (33\%, 5 drops, excess) in THF $(5 \mathrm{~mL})$ was stirred at $0{ }^{\circ} \mathrm{C}$ for $2 \mathrm{~h}$. The solvent was removed under reduced pressure to yield the crude product, which was purified by CombiFlash column chromatography (gradient elution, $\mathrm{MeOH} / \mathrm{CH}_{2} \mathrm{Cl}_{2} \mathrm{O}$ to $3 \%$ ) to afford $110 \mathrm{mg}$ of 5e: 54\% yield; yellow solid; mp 200-202 ${ }^{\circ} \mathrm{C}$; ${ }^{1} \mathrm{H}$ NMR $\delta 2.14(6 \mathrm{H}$, s, 2 $\left.\times \mathrm{CH}_{3}\right), 2.36\left(6 \mathrm{H}, \mathrm{s}, 2 \times \mathrm{NCH}_{3}\right), 3.62\left(2 \mathrm{H}, \mathrm{s}, \mathrm{CH}_{2} \mathrm{~N}\right), 5.85(1 \mathrm{H}, \mathrm{d}, J=16.8 \mathrm{~Hz},=\mathrm{CH}), 6.27$ (1H, s, ArH-6), 7.03 (2H, d, $\left.J=8.8 \mathrm{~Hz}, \mathrm{ArH}-2^{\prime}, 6^{\prime}\right), 7.21$ (2H, s, ArH-3" $\left.5^{\prime \prime}\right), 7.33$ (1H, d, $J$ $=16.8 \mathrm{~Hz}), 7.45\left(2 \mathrm{H}, \mathrm{d}, J=8.8 \mathrm{~Hz}, \mathrm{ArH}-3^{\prime}, 5^{\prime}\right), 8.40(1 \mathrm{H}, \mathrm{s}, \mathrm{ArH}-3), 9.63(1 \mathrm{H}, \mathrm{s}, \mathrm{NH})$; MS $\mathrm{m} / \mathrm{z}(\%) 423.2(\mathrm{M}-44,100), 468.4(\mathrm{M}+1,6.2)$.

$\mathrm{N}^{1}$-(4'-Cyanophenyl)-5-(4"-cyanovinyl-2" ,6"-dimethylphenoxy)-4-(Ncyclopropylamino)methyl-2-nitroaniline (5f)-Preparation is the same as that of $\mathbf{5 e}$. Starting with 4c (200 mg, $0.44 \mathrm{mmol})$ and cyclopropanamine ( 2 drops, excess) to produce 
$130 \mathrm{mg}$ of 5f: $62 \%$ yield; yellow solid; mp $102-104{ }^{\circ} \mathrm{C} ;{ }^{1} \mathrm{H}$ NMR $\delta 0.65\left(4 \mathrm{H}, \mathrm{m}, 2 \times \mathrm{CH}_{2}\right)$, $2.18\left(6 \mathrm{H}, \mathrm{s}, 2 \times \mathrm{CH}_{3}\right), 2.40(1 \mathrm{H}, \mathrm{m}, \mathrm{CH}), 4.22\left(2 \mathrm{H}, \mathrm{s}, \mathrm{CH}_{2} \mathrm{~N}\right), 5.85(2 \mathrm{H}, \mathrm{d}, J=16.8 \mathrm{~Hz}$, $=\mathrm{CH}), 6.27$ (1H, s, ArH-6), 7.04 (2H, d, $\left.J=8.8 \mathrm{~Hz}, \mathrm{ArH}-2^{\prime}, 6^{\prime}\right), 7.21$ (2H, s, ArH-3", $\left.5^{\prime \prime}\right)$, $7.31(2 \mathrm{H}, \mathrm{d}, J=16.8 \mathrm{~Hz}, \mathrm{CH}=), 7.49\left(2 \mathrm{H}, \mathrm{d}, J=8.8 \mathrm{~Hz}, \mathrm{ArH}-3^{\prime}, 5^{\prime}\right), 8.52(1 \mathrm{H}, \mathrm{s}, \mathrm{ArH}-3)$, $9.67(1 \mathrm{H}, \mathrm{s}, \mathrm{NH})$; MS m/z (\%) $480.2(\mathrm{M}+1,4.8), 423.2(\mathrm{M}-56,100)$.

$\mathrm{N}^{1}$-(4'-Cyanophenyl)-5-(4" -cyanovinyl-2", 6" -dimethylphenoxy)-4-(Nmethylpiperazin-1-yl)methyl-2-nitroaniline (5g)_Preparation is the same as that of 5e. Starting with $4 \mathbf{c}(70 \mathrm{mg}, 0.15 \mathrm{mmol})$ and $N$-methylpiperazine ( 2 drops, excess) to afford $58 \mathrm{mg}$ of 5g: $73 \%$ yield; yellow solid; mp $194.2-195.3{ }^{\circ} \mathrm{C}$; ${ }^{1} \mathrm{H}$ NMR $\delta 2.14(6 \mathrm{H}, \mathrm{s}, 2 \times$ $\left.\mathrm{CH}_{3}\right), 2.32\left(3 \mathrm{H}, \mathrm{s}, \mathrm{NCH}_{3}\right), 2.62\left(8 \mathrm{H}, \mathrm{m}, 4 \times \mathrm{CH}_{2}\right), 3.68\left(2 \mathrm{H}, \mathrm{s}, \mathrm{CH}_{2} \mathrm{~N}\right), 5.84(2 \mathrm{H}, \mathrm{d}, J=16.4$ $\mathrm{Hz},=\mathrm{CH}), 6.26(1 \mathrm{H}, \mathrm{s}, \mathrm{ArH}-6), 7.03\left(2 \mathrm{H}, \mathrm{d}, J=8.4 \mathrm{~Hz}, \mathrm{ArH}-2^{\prime}, 6^{\prime}\right), 7.21$ (2H, s, ArH-3", $\left.5^{\prime \prime}\right), 7.33(1 \mathrm{H}, \mathrm{d}, J=16.4 \mathrm{~Hz}, \mathrm{CH}=), 7.46\left(2 \mathrm{H}, \mathrm{d}, J=8.4 \mathrm{~Hz}, \mathrm{ArH}-3^{\prime}, 5^{\prime}\right), 8.35(1 \mathrm{H}, \mathrm{s}$, ArH-3), 9.64 (1H, s, NH); MS m/z (\%) 423.3 (M - 99, 100), 523.3 (M + 1, 83).

4-Acetoxymethyl-N ${ }^{1}-\left(4^{\prime}\right.$-cyanophenyl)-5-(4" -cyanovinyl-2" ,6" dimethylphenoxy)-2-nitroaniline (5h)-A mixture of $\mathbf{4 b}(93 \mathrm{mg}, 0.21 \mathrm{mmol})$ and $\mathrm{NaOH}$ (30 mg, $0.75 \mathrm{mmol})$ in acetic anhydride $(5 \mathrm{~mL})$ was heated at $100{ }^{\circ} \mathrm{C}$ under microwave irradiation while the mixture was being stirred for $5 \mathrm{~min}$. The mixture was poured into ice-water, and the precipitated yellow solid was collected and dried to yield 93 mg of 5h: 95\% yield; mp $229-231{ }^{\circ} \mathrm{C} ;{ }^{1} \mathrm{H}$ NMR (DMSO- $\left.d_{6}\right) \delta 2.08\left(9 \mathrm{H}, \mathrm{s}, 2 \times \mathrm{CH}_{3}\right.$ and $\left.\mathrm{CH}_{3} \mathrm{C}=\mathrm{O}\right), 5.26\left(2 \mathrm{H}, \mathrm{s}, \mathrm{CH}_{2} \mathrm{O}\right), 6.04(1 \mathrm{H}, \mathrm{s}, \mathrm{ArH}-6), 6.43(1 \mathrm{H}, \mathrm{d}, J=16.8 \mathrm{~Hz},=\mathrm{CH}), 7.15$ $\left(2 \mathrm{H}, \mathrm{d}, J=8.4 \mathrm{~Hz}, \mathrm{ArH}-2^{\prime}, 6^{\prime}\right), 7.49$ (2H, s, ArH-3", $\left.5^{\prime \prime}\right), 7.58(1 \mathrm{H}, \mathrm{d}, J=16.8 \mathrm{~Hz}, \mathrm{CH}=)$, $7.61\left(2 \mathrm{H}, \mathrm{d}, J=8.4 \mathrm{~Hz}, \mathrm{ArH}-3^{\prime}, 5^{\prime}\right), 8.33(1 \mathrm{H}, \mathrm{s}, \mathrm{ArH}-3), 9.57(1 \mathrm{H}, \mathrm{s}, \mathrm{NH}) ; \mathrm{MS} m / z(\%)$ $483.4(\mathrm{M}+1,47.4), 505.2(\mathrm{M}+\mathrm{Na}, 100)$.

$\mathrm{N}^{1}$-(4'-Cyanophenyl)-5-(4" -cyanovinyl-2",6" -dimethylphenoxy)-4[(cyclopropane carbonyl)oxy]methyl 2-nitroaniline (5i)—A mixture of $4 \mathbf{b}(80 \mathrm{mg}$, $0.18 \mathrm{mmol}$ ) and cyclopropanecarbonyl chloride (28.6 mg $0.27 \mathrm{mmol})$ in $\mathrm{CH}_{2} \mathrm{Cl}_{2}(5 \mathrm{~mL})$ in the presence of pyridine $(1 \mathrm{~mL})$ was stirred at room temperature for $4 \mathrm{~h}$, washed with aqueous $\mathrm{HCl}$ (5\%), water, and brine, successively, and dried over $\mathrm{MgSO}_{4}$. After removal of solvent in vacuo, the residue was purified with PTLC [30:70:0.8 (v/v/v) cyclohexane/ $\mathrm{CH}_{2} \mathrm{Cl}_{2}$ /acetone] to afford $74 \mathrm{mg}$ of 5i: $80 \%$ yield; yellow solid; mp $190-191{ }^{\circ} \mathrm{C} ;{ }^{1} \mathrm{H}$ NMR

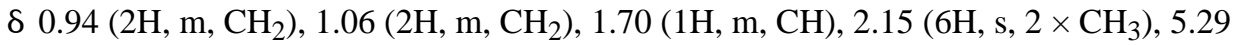
$\left(2 \mathrm{H}, \mathrm{s}, \mathrm{CH}_{2} \mathrm{O}\right), 5.85(1 \mathrm{H}, \mathrm{d}, J=16.4 \mathrm{~Hz},=\mathrm{CH}), 6.27(1 \mathrm{H}, \mathrm{s}, \mathrm{ArH}-6), 7.06(2 \mathrm{H}, \mathrm{d}, J=8.8$ $\left.\mathrm{Hz}, \mathrm{ArH}-2^{\prime}, 6^{\prime}\right), 7.21\left(2 \mathrm{H}, \mathrm{s}, \mathrm{ArH}-3^{\prime \prime}, 5^{\prime \prime}\right), 7.33(1 \mathrm{H}, \mathrm{d}, J=16.4 \mathrm{~Hz}, \mathrm{CH}=), 7.48(2 \mathrm{H}, \mathrm{d}, J=$ $8.8 \mathrm{~Hz}, \mathrm{ArH}-3$ ', 5'), 8.40 (1H, s, ArH-3), 9.74 (1H, s, NH); MS m/z (\%) 533.5 (M + 23, $100)$.

\section{$\mathrm{N}^{1}$ (4'-Cyanophenyl)-5-(4" -cyanovinyl-2" , $^{\prime \prime}$-dimethylphenoxy)-4-[(N-} methylcarbamyl)oxy]methyl-2-nitroaniline (5j)—A mixture of $\mathbf{4 b}(150 \mathrm{mg}, 0.34$ $\mathrm{mmol}$ ) and methylcarbamic chloride $(320 \mathrm{mg}, 3.4 \mathrm{mmol})$ in pyridine $(4.5 \mathrm{~mL})$ was heated at $120{ }^{\circ} \mathrm{C}$ under microwave irradiation while the mixture was being stirred for $30 \mathrm{~min}$. The mixture was poured into ice-water, and the precipitated yellow solid was collected, washed with water, and dried to produce $157 \mathrm{mg}$ of $5 \mathrm{j}$ : $93 \%$ yield; mp $210-211{ }^{\circ} \mathrm{C} ;{ }^{1} \mathrm{H}$ NMR 
$\left(\right.$ DMSO- $\left.d_{6}\right) \delta 2.14\left(6 \mathrm{H}, \mathrm{s}, 2 \times \mathrm{CH}_{3}\right), 2.86\left(3 \mathrm{H}, \mathrm{d}, J=4.8 \mathrm{~Hz}, \mathrm{NCH}_{3}\right), 5.29\left(2 \mathrm{H}, \mathrm{s}, \mathrm{ArCH}_{2} \mathrm{O}\right)$, $5.84(1 \mathrm{H}, \mathrm{d}, J=16.8 \mathrm{~Hz}, \mathrm{CH}=), 6.26(1 \mathrm{H}, \mathrm{s}, \mathrm{ArH}-6), 7.05\left(2 \mathrm{H}, \mathrm{d}, J=8.4 \mathrm{~Hz}, \mathrm{ArH}-2^{\prime}, 6^{\prime}\right)$, $7.21\left(2 \mathrm{H}, \mathrm{s}, \mathrm{ArH}-3^{\prime \prime}, 5^{\prime \prime}\right), 7.32(1 \mathrm{H}, \mathrm{d}, J=16.8 \mathrm{~Hz}, \mathrm{CH}=), 7.47(2 \mathrm{H}, \mathrm{d}, J=8.4 \mathrm{~Hz}, \mathrm{ArH}-3$ ', 5'), 8.39 (1H, s, ArH-3), $9.71(1 \mathrm{H}, \mathrm{s}, \mathrm{NH})$; $\mathrm{MS} \mathrm{m} / \mathrm{z}(\%) 514.9\left(\mathrm{M}+\mathrm{NH}_{3}, 100\right)$.

$\mathrm{N}^{1}$-(4'-Cyanophenyl)-5-(4"-cyanovinyl-2",6" -dimethylphenoxy)-4methoxymethyl-2-nitroaniline (5k)—A mixture of $\mathrm{BiCl}_{3}(98 \mathrm{mg}, 0.31 \mathrm{mmol})$ and $\mathrm{MeOH}(15 \mu \mathrm{L})$ in $\mathrm{CCl}_{4}(2 \mathrm{~mL})$ was first stirred at $\mathrm{rt}$ for $20 \mathrm{~min}$, followed by the addition of $4 \mathbf{b}(110 \mathrm{mg}, 0.25 \mathrm{mmol})$ in $\mathrm{CH}_{2} \mathrm{Cl}_{2}(5 \mathrm{~mL})$. The mixture was stirred at room temperature for $4 \mathrm{~h}$. The solid was filtered out, and the filtrate was condensed under reduced pressure to gain crude product. It was purified by a flash column to produce $80 \mathrm{mg}$ of pure $5 \mathbf{k}$ in $71 \%$ yield: yellow solid; mp 205-207 ${ }^{\circ} \mathrm{C} ;{ }^{1} \mathrm{H}$ NMR $\delta 2.13\left(6 \mathrm{H}, \mathrm{s}, 2 \times \mathrm{CH}_{3}\right), 3.52\left(3 \mathrm{H}, \mathrm{s}, \mathrm{OCH}_{3}\right), 4.62$ $\left(2 \mathrm{H}, \mathrm{s}, \mathrm{CH}_{2} \mathrm{O}\right), 5.84(1 \mathrm{H}, \mathrm{d}, J=16.8 \mathrm{~Hz},=\mathrm{CH}), 6.26(1 \mathrm{H}, \mathrm{s}, \mathrm{ArH}-6), 7.04(2 \mathrm{H}, \mathrm{d}, J=8.8$ $\left.\mathrm{Hz}, \mathrm{ArH}-2^{\prime}, 6^{\prime}\right), 7.20\left(2 \mathrm{H}, \mathrm{s}, \mathrm{ArH}-3^{\prime \prime}, 5^{\prime \prime}\right), 7.32(1 \mathrm{H}, \mathrm{d}, J=16.8 \mathrm{~Hz}, \mathrm{CH}=), 7.46(2 \mathrm{H}, \mathrm{d}, J=$ $\left.8.8 \mathrm{~Hz}, \mathrm{ArH}-3^{\prime}, 5^{\prime}\right), 8.39$ (1H, s, ArH-3), $9.68(1 \mathrm{H}, \mathrm{s}, \mathrm{NH})$; $\mathrm{MS} \mathrm{m} / \mathrm{z}(\%) 455.4(\mathrm{M}+1,100)$.

(E)-3-[4-(Benzyloxy)-3,5-dimethylphenyl]acrylonitrile (8a)-A mixture of 4hydroxy-3,5-dimethylbenzaldehyde (7a) $(4 \mathrm{~g}, 26.7 \mathrm{mmol})$ and 1-(chloromethyl)benzene (4.1 $\mathrm{g}, 32.0 \mathrm{mmol})$ in $\mathrm{CH}_{3} \mathrm{CN}(70 \mathrm{~mL})$ in the presence of $\mathrm{K}_{2} \mathrm{CO}_{3}(7.4 \mathrm{~g}, 53.6 \mathrm{mmol}$, excess) was refluxed for $3 \mathrm{~h}$. The solid $\mathrm{K}_{2} \mathrm{CO}_{3}$ was filtered out and washed with EtOAc several times. After removal of the organic solvent under reduced pressure, the residue was dissolved in THF $(15 \mathrm{~mL})$ and then slowly added to a mixture of $(\mathrm{EtO}){ }_{2} \mathrm{P}(\mathrm{O}) \mathrm{CH}_{2} \mathrm{CN}(7.1 \mathrm{~g}, 40 \mathrm{mmol})$ and $t$-BuOK $(6 \mathrm{~g}, 53.6 \mathrm{mmol})$ in THF $(10 \mathrm{~mL})$ at $0{ }^{\circ} \mathrm{C}$ (ice-water bath) while the mixture was being stirred for $1 \mathrm{~h}$. The mixture was then stirred for an additional $1 \mathrm{~h}$ and monitored by TLC until the reaction reached completion. The mixture was poured into ice-water, and the solid product was collected, washed with water to neutral, and dried to afford $6.45 \mathrm{~g}$ of 8a (92\% yield, white solid), which was ready for the next reaction directly without further purification.

(E)-3-[(4-Benzyloxy)-3,5-dimethoxyphenyl]acrylonitrile (8b)-The preparation was same as that of 8a. 4-Hydroxy-3,5-dimethoxybenzal-dehyde (7b, $2.41 \mathrm{~g}, 13.2 \mathrm{mmol})$ was first reacted with 1-(chloromethyl)-benzene $(2.02 \mathrm{~g}, 15.9 \mathrm{mmol})$ in the presence of $\mathrm{K}_{2} \mathrm{CO}_{3}$ (3.64 g, $26.4 \mathrm{mmol})$, following condensation with $(\mathrm{EtO}){ }_{2} \mathrm{P}(\mathrm{O}) \mathrm{CH}_{2} \mathrm{CN}(3.6 \mathrm{~g}, 20.4 \mathrm{mmol})$ to afford $1.4 \mathrm{~g}$ of $\mathbf{8 b}$ (36\% yield, colorless oil), which was purified on a flash column chromatograph (gradient elution, EtOAc/ petroleum ether, 0 to $10 \%$ ).

\section{(E)-3-[4-(Benzyloxy)-3-bromo-5-methoxyphenyl]acrylonitrile (8c)-The}

preparation was the same as that of 8a. Starting with 3-bromo-4-hydroxy-5methoxybenzaldehyde (7c, $2.0 \mathrm{~g}, 8.66 \mathrm{mmol})$, 1-(chloromethyl)benzene (1.3 g, $10.4 \mathrm{mmol})$, and $\mathrm{K}_{2} \mathrm{CO}_{3}(2.4 \mathrm{~g}, 17.3 \mathrm{mmol})$, followed by condensation with $(\mathrm{EtO}){ }_{2} \mathrm{P}(\mathrm{O}) \mathrm{CH}_{2} \mathrm{CN}(1.1 \mathrm{~g}$, $8.9 \mathrm{mmol})$ in the presence of $t$-BuOK $(1.0 \mathrm{~g}, 8.9 \mathrm{mmol})$ to afford $1.3 \mathrm{~g}$ of $\mathbf{8 c}$, which was purified by a flash column chromatograph (gradient elution, EtOAc/petroleum ether, 0 to 10\%): 44\% yield; white solid; mp 102.4-103.8 ${ }^{\circ} \mathrm{C} ;{ }^{1} \mathrm{H}$ NMR $\delta 3.90(3 \mathrm{H}, \mathrm{s}, \mathrm{OMe}), 5.08(2 \mathrm{H}$, s, $\left.\mathrm{ArCH}_{2} \mathrm{O}\right), 5.79(1 \mathrm{H}, \mathrm{d}, J=16.4 \mathrm{~Hz},=\mathrm{CN}), 6.89(1 \mathrm{H}, \mathrm{s}, \mathrm{ArH}-5), 7.26(1 \mathrm{H}, \mathrm{d}, J=16.4 \mathrm{~Hz}$, 
$\mathrm{CH}=), 7.27(1 \mathrm{H}, \mathrm{s}, \mathrm{ArH}-2), 7.36\left(3 \mathrm{H}, \mathrm{m}, \mathrm{ArH}-3^{\prime}, 4^{\prime}, 5^{\prime}\right), 7.51\left(2 \mathrm{H}, \mathrm{d}, J=7.6 \mathrm{~Hz}, \mathrm{ArH}-2^{\prime}\right.$, $\left.6^{\prime}\right) ; \mathrm{MS} \mathrm{m} / \mathrm{z}(\%) 365.9\left(\mathrm{M}+\mathrm{NH}_{3}, 100\right), 368.1(80)$.

4-Cyanoethyl-2,6-dimethylphenol (9a)-The mixture of $8 \mathrm{a}(6.4 \mathrm{~g}, 24.3 \mathrm{mmol})$ in EtOH $(50 \mathrm{~mL})$ with $\mathrm{H}_{2}$ gas in the presence of excess Pd-C (10\%) under a pressure of $30 \mathrm{psi}$ was shaken for $2 \mathrm{~h}$ to yield $9 \mathrm{a}$. After removal of $\mathrm{Pd}-\mathrm{C}$ and solvent, the residue was purified by a flash column chromatograph (gradient elution, EtOAc/petroleum ether, 10 to $0 \%$ ) to produce pure $3.89 \mathrm{~g}$ of 9a: $90 \%$ yield; white solid; mp $135.1-136.2{ }^{\circ} \mathrm{C} ;{ }^{1} \mathrm{H}$ NMR $2.22(6 \mathrm{H}$, $\left.\mathrm{s}, 2 \times \mathrm{CH}_{3}\right), 2.56\left(2 \mathrm{H}, \mathrm{t}, J=7.2 \mathrm{~Hz}, \mathrm{CH}_{2} \mathrm{CN}\right), 2.82\left(2 \mathrm{H}, \mathrm{t}, J=7.2 \mathrm{~Hz}, \mathrm{ArCH}_{2}\right), 6.83(2 \mathrm{H}, \mathrm{s}$, $\mathrm{ArH}-2,6) ; \mathrm{MS} m / z(\%) 193.2\left(\mathrm{M}+\mathrm{NH}_{3}, 100\right)$.

4-Cyanoethyl-2,6-dimethoxyphenol (9b)-The preparation was the same as that of $9 \mathbf{a}$. Starting with $\mathbf{8 b}(1.4 \mathrm{~g}, 4.7 \mathrm{mmol})$ in EtOAc $(25 \mathrm{~mL})$ to afford $920 \mathrm{mg}$ of $\mathbf{9 b}$ in $94 \%$ yield, which was ready for the next reaction without further purification.

2-Bromo-4-cyanoethyl-6-methoxyphenol (9c)—The mixture of $\mathbf{8 c}(800 \mathrm{mg}, 2.33$ mmol), $\mathrm{Pd}-\mathrm{C}(5 \%, 50 \mathrm{mg})$, and $\mathrm{ZnCl}_{2}$ (300 mg, $\left.2.20 \mathrm{mmol}\right)$ in EtOAc $(25 \mathrm{~mL})$ with $\mathrm{H}_{2}$ gas under a pressure of $40 \mathrm{psi}$ was shaken for $1.5 \mathrm{~h}$ to afford $500 \mathrm{mg}$ of $9 \mathrm{c}$ : $74 \%$ yield; white solid; mp 85.2-87.1 ${ }^{\circ} \mathrm{C} ;{ }^{1} \mathrm{H} \mathrm{NMR} \delta 2.60\left(2 \mathrm{H}, \mathrm{d}, J=8.8 \mathrm{~Hz}, \mathrm{CH}_{2} \mathrm{CN}\right), 2.87(2 \mathrm{H}, \mathrm{t}, J=8.8$ $\left.\mathrm{Hz}, \mathrm{ArCH}_{2}\right), 3.92\left(1 \mathrm{H}, \mathrm{s}, \mathrm{OCH}_{3}\right), 5.88(1 \mathrm{H}, \mathrm{s}, \mathrm{OH}), 6.71(1 \mathrm{H}, \mathrm{d}, J=1.2 \mathrm{~Hz}, \mathrm{ArH}-6), 6.96$ $(1 \mathrm{H}, \mathrm{d}, J=1.2 \mathrm{~Hz}, \mathrm{ArH}-2) ; \mathrm{MS} m / z(\%) 273.2\left(\mathrm{M}+\mathrm{NH}_{3}, 100\right), 275.2(100)$.

$\mathbf{N}^{1}$-(4-Cyanophenyl)-4,5-dichloro-2-nitroanilines (10b)-A mixture of 2,4,5trichloronitrobenzene (200 mg, $0.89 \mathrm{mmol})$, 4-aminobenzonitrile (126 mg, $1.08 \mathrm{mmol})$, and $\mathrm{Cs}_{2} \mathrm{CO}_{3}(580 \mathrm{mg}, 1.77 \mathrm{mmol})$ in DMF $(2 \mathrm{~mL})$ was heated at $80{ }^{\circ} \mathrm{C}$ under microwave irradiation while the mixture was being stirred for $20 \mathrm{~min}$. The mixture was poured into icewater and adjusted to $\mathrm{pH} 3$; then precipitated solid product was collected by filtration and purified by a silica column with the CombiFlash chromatography system (gradient elution, $\mathrm{CH}_{2} \mathrm{C}_{2}$ / petroleum ether, 0 to $70 \%$ ) to give $31 \mathrm{mg}$ of 10b: $13 \%$ yield; orange solid; mp 180$182{ }^{\circ} \mathrm{C} ;{ }^{1} \mathrm{H}$ NMR $\delta 7.34\left(2 \mathrm{H}, \mathrm{d}, J=8.8 \mathrm{~Hz}, \mathrm{ArH}-2^{\prime}, 6^{\prime}\right), 7.50(1 \mathrm{H}, \mathrm{s}, \mathrm{ArH}-6), 7.32(2 \mathrm{H}, \mathrm{d}, J$ $\left.=8.4 \mathrm{~Hz}, \mathrm{ArH}-3^{\prime}, 5^{\prime}\right), 8.36(1 \mathrm{H}, \mathrm{s}, \mathrm{ArH}-3), 9.42(1 \mathrm{H}, \mathrm{s}, \mathrm{NH}) ; \mathrm{MS} \mathrm{m} / \mathrm{z}(\%) 308.1(\mathrm{M}+1$, 100), $310.3(\mathrm{M}+3,25)$.

5-[4"-(2-Cyanoethyl)-N'-(4'-cyanophenyl)-2",6" -dimethylphe-noxy]-4methylcarbonyl-2-nitroaniline (11a)_A mixture of 10a $(6 \mathrm{~g}, 18.1 \mathrm{mmol})$, which was prepared according to the method described in ref 11 , and $9 \mathbf{a}(3.29 \mathrm{~g}, 19.0 \mathrm{mmol})$ in $60 \mathrm{~mL}$ of DMF in the presence of $\mathrm{K}_{2} \mathrm{CO}_{3}(4.50 \mathrm{~g}, 32.6 \mathrm{mmol})$ was heated at $110{ }^{\circ} \mathrm{C}$ while the mixture was being stirred for $4 \mathrm{~h}$. The mixture was poured into ice-water, and precipitated yellow solid was collected to produce $8.0 \mathrm{~g}$ of pure 11a: $94 \%$ yield; mp $179-181{ }^{\circ} \mathrm{C} ;{ }^{1} \mathrm{H}$ NMR $\delta 2.12\left(6 \mathrm{H}, \mathrm{s}, 2 \times \mathrm{CH}_{3}\right), 2.61\left(2 \mathrm{H}, \mathrm{t}, J=6.6 \mathrm{~Hz}, \mathrm{CH}_{2} \mathrm{CN}\right), 2.87(2 \mathrm{H}, \mathrm{t}, J=6.6 \mathrm{~Hz}$, $\left.\mathrm{ArCH}_{2}\right), 3.96$ (3H, s, $\left.\mathrm{OCH}_{3}\right), 6.26$ (1H, s, ArH-6), 6.97 (2H, s, ArH-3", 5"), 7.07 (2H, d, $J=$ $\left.8.8 \mathrm{~Hz}, \mathrm{ArH}-2^{\prime}, 6^{\prime}\right), 7.54\left(2 \mathrm{H}, \mathrm{d}, J=8.8 \mathrm{~Hz}, \mathrm{ArH}-3^{\prime}, 5^{\prime}\right), 8.99(1 \mathrm{H}, \mathrm{s}, \mathrm{ArH}-3), 9.85(1 \mathrm{H}, \mathrm{s}$, $\mathrm{NH}) ; \mathrm{MS} \mathrm{m} / \mathrm{z}(\%) 439.2(\mathrm{M}-31,100), 471.2(\mathrm{M}+1,66)$.

4-Carboxy-5-[4"-(2-cyanoethyl)-2" ,6" -dimethylphenoxy]-N1-(4'cyanophenyl)-2-nitroaniline (11b) - The preparation was the same as that of $\mathbf{4 a}$. 
Starting with 11a ( $2.5 \mathrm{~g}, 5.3 \mathrm{mmol})$ for $8 \mathrm{~h}$ to give $2.42 \mathrm{~g}$ of pure 11b: $99 \%$ yield; yellow solid; mp 220.0-222.0 ${ }^{\circ} \mathrm{C} ;{ }^{1} \mathrm{H}$ NMR $\delta 2.13\left(6 \mathrm{H}, \mathrm{s}, 2 \times \mathrm{CH}_{3}\right), 2.62(2 \mathrm{H}, \mathrm{t}, J=7.2 \mathrm{~Hz}$, $\left.\mathrm{CH}_{2} \mathrm{CN}\right), 2.88\left(2 \mathrm{H}, \mathrm{t}, J=7.2 \mathrm{~Hz}, \mathrm{ArCH}_{2}\right), 6.26(1 \mathrm{H}, \mathrm{s}, \mathrm{ArH}-6), 7.00$ (2H, s, ArH-3", 5"), $7.10\left(2 \mathrm{H}, \mathrm{d}, J=8.8 \mathrm{~Hz}, \mathrm{ArH}-2^{\prime}, 6^{\prime}\right), 7.70\left(2 \mathrm{H}, \mathrm{d}, J=8.8 \mathrm{~Hz}, \mathrm{ArH}-3^{\prime}, 5^{\prime}\right), 9.17(1 \mathrm{H}, \mathrm{s}$, ArH-3), 9.90 (1H, s, NH); MS m/z (\%) 479.1 (M + Na, 100).

5-[4"-(2-Cyanoethyl)-2" ,6"-dimethylphenoxy]-N1'-(4'-cyanophenyl)-4hydroxymethyl-2-nitroaniline (11c)-The preparation was the same as that of $\mathbf{4 b}$. Starting with 11a $(500 \mathrm{mg}, 1.06 \mathrm{mmol})$ with $\mathrm{LiBH}_{4}(70 \mathrm{mg}, 3.18 \mathrm{mmoL})$ in THF $(15 \mathrm{~mL})$ containing $\mathrm{MeOH}$ (13 drops) at $0{ }^{\circ} \mathrm{C}$ for $6 \mathrm{~h}$ to afford $400 \mathrm{mg}$ of 11c: yellow solid; $85 \%$ yield; mp 152-154 ${ }^{\circ} \mathrm{C} ;{ }^{1} \mathrm{H}$ NMR $\delta 2.12\left(6 \mathrm{H}, \mathrm{s}, 2 \times \mathrm{CH}_{3}\right), 2.61\left(2 \mathrm{H}, \mathrm{t}, J=7.2 \mathrm{~Hz}, \mathrm{CH}_{2} \mathrm{CN}\right)$, $2.88\left(2 \mathrm{H}, \mathrm{t}, J=7.2 \mathrm{~Hz}, \mathrm{ArCH}_{2}\right), 4.88\left(2 \mathrm{H}, \mathrm{m}, \mathrm{CH}_{2} \mathrm{O}\right), 6.27(1 \mathrm{H}, \mathrm{s}, \mathrm{ArH}-6), 6.99(2 \mathrm{H}, \mathrm{s}$, ArH-3", $\left.5^{\prime \prime}\right), 7.04\left(2 \mathrm{H}, \mathrm{d}, J=8.8 \mathrm{~Hz}, \mathrm{ArH}-2^{\prime}, 6^{\prime}\right), 7.50\left(2 \mathrm{H}, \mathrm{d}, J=8.8 \mathrm{~Hz}, \mathrm{ArH}-3^{\prime}, 5^{\prime}\right), 8.35$ $(1 \mathrm{H}, \mathrm{s}, \mathrm{ArH}-3), 9.72(1 \mathrm{H}, \mathrm{s}, \mathrm{NH})$; MS m/z (\%) $465.1(\mathrm{M}+\mathrm{Na}, 100)$.

5-[4"-(2-Cyanoethyl)-2" ,6"-dimethylphenoxy]-N'-(4'-cyanophenyl)-4isopropylcarbamoyl-2-nitroaniline (11d)—The preparation is the same as that of 5a-c. Starting with carboxylic acid compound $11 \mathrm{~b}(250 \mathrm{mg}, 0.55 \mathrm{mmol})$ and isopropylamine (4 drops, excess) to afford $220 \mathrm{mg}$ of $\mathbf{1 1 d}$ : $81 \%$ yield; mp 180.0-181.6 ${ }^{\circ} \mathrm{C} ;{ }^{1} \mathrm{H}$ NMR $\delta 1.27$ $\left(6 \mathrm{H}, \mathrm{d}, J=6.4 \mathrm{~Hz}, 2 \times \mathrm{CH}_{3}\right), 2.13\left(6 \mathrm{H}, \mathrm{s}, 2 \times \mathrm{CH}_{3}\right), 2.64\left(2 \mathrm{H}, \mathrm{t}, J=7.2 \mathrm{~Hz}, \mathrm{CH}_{2} \mathrm{CN}\right), 2.90$ $\left(2 \mathrm{H}, \mathrm{t}, J=7.2 \mathrm{~Hz}, \mathrm{ArCH}_{2}\right), 4.35(1 \mathrm{H}, \mathrm{m}, \mathrm{CH}), 6.28(1 \mathrm{H}, \mathrm{s}, \mathrm{ArH}-6), 7.03\left(2 \mathrm{H}, \mathrm{s}, \mathrm{ArH}-3^{\prime \prime}, 5^{\prime \prime}\right)$, $7.06\left(2 \mathrm{H}, \mathrm{d}, J=8.8 \mathrm{~Hz}, \mathrm{ArH}-2^{\prime}, 6^{\prime}\right), 7.51(1 \mathrm{H}, \mathrm{d}, J=7.6 \mathrm{~Hz}, \mathrm{CONH}), 7.53(2 \mathrm{H}, \mathrm{d}, J=8.8$ $\left.\mathrm{Hz}, \mathrm{ArH}-3^{\prime}, 5^{\prime}\right), 9.27(1 \mathrm{H}, \mathrm{s}, \mathrm{ArH}-3), 9.76(1 \mathrm{H}, \mathrm{s}, \mathrm{NH})$; MS m/z (\%) $498.2(\mathrm{M}+1,100)$.

4-Chloromethyl-5-[4"-(2-cyanoethyl)-2" ,6" -dimethylphenoxy]-N1-(4'cyanophenyl)-2-nitroaniline (11e)-The preparation was the same as that of $\mathbf{4 c}$. Starting with 11c (613 mg, $1.39 \mathrm{mmol}$ ) with 2,4,6-trichloro[1,3,5]triazine (306 mg, 1.66 $\mathrm{mmol}$ ) to afford $500 \mathrm{mg}$ of pure 11e: $86 \%$ yield; yellow solid; mp $196-197{ }^{\circ} \mathrm{C} ;{ }^{1} \mathrm{H}$ NMR $\delta$ $2.13\left(6 \mathrm{H}, \mathrm{s}, 2 \times \mathrm{CH}_{3}\right), 2.61\left(2 \mathrm{H}, \mathrm{t}, J=7.2 \mathrm{~Hz}, \mathrm{CH}_{2} \mathrm{CN}\right), 2.88\left(2 \mathrm{H}, \mathrm{t}, J=7.2 \mathrm{~Hz}, \mathrm{CH}_{2} \mathrm{Ar}\right)$, $4.77\left(2 \mathrm{H}, \mathrm{s}, \mathrm{CH}_{2} \mathrm{Cl}\right), 6.25(1 \mathrm{H}, \mathrm{s}, \operatorname{ArH}-6), 6.99\left(2 \mathrm{H}, \mathrm{s}, \mathrm{ArH}-3^{\prime \prime}, 5^{\prime \prime}\right), 7.07(2 \mathrm{H}, \mathrm{d}, J=8.8 \mathrm{~Hz}$, ArH-2' $\left.6^{\prime}\right), 7.52\left(2 \mathrm{H}, \mathrm{d}, J=8.8 \mathrm{~Hz}, \mathrm{ArH}-3^{\prime}, 5^{\prime}\right), 8.40(1 \mathrm{H}, \mathrm{s}, \mathrm{ArH}-3), 9.78(1 \mathrm{H}, \mathrm{s}, \mathrm{NH}) ; \mathrm{MS}$ $\mathrm{m} / \mathrm{z}(\%) 461.3(\mathrm{M}+1,100), 463.3(\mathrm{M}+3,10)$.

4-Amino-5-[4" -(2-cyanoethyl)-2" ,6"-dimethylphenoxy]-N1'-(4' -cyanophenyl)-2nitroaniline (11f) - A mixture of $\mathbf{1 1 b}$ (200 $\mathrm{mg}, 0.44 \mathrm{mmol})$ and diphenylphosphorylazide (DPPA, $112 \mu \mathrm{L})$ in THF $(8 \mathrm{~mL})$ in the presence of $\mathrm{Et}_{3} \mathrm{~N}(400 \mu \mathrm{L})$ was stirred at $25^{\circ} \mathrm{C}$ for 3 h. Water $(5 \mathrm{~mL})$ was added, and then the reaction mixture was refluxed for an additional $5 \mathrm{~h}$. The solvent was diluted with $\mathrm{H}_{2} \mathrm{O}$ and extracted with EtOAc several times. The combined organic filtrate was washed with brine and dried over anhydrous $\mathrm{Na}_{2} \mathrm{SO}_{4}$. After removal of solvent, the residue was purified by flash chromatography (gradient elution, $\mathrm{MeOH} /$ petroleum ether, 10 to $60 \%$ ) to afford $78 \mathrm{mg}$ of $\mathbf{1 1 f}$ : $42 \%$ yield; mp $211-212{ }^{\circ} \mathrm{C}$; ${ }^{1} \mathrm{H}$ NMR (DMSO- $\left.d_{6}\right) \delta 2.07\left(6 \mathrm{H}, \mathrm{s}, 2 \times \mathrm{CH}_{3}\right), 3.79\left(4 \mathrm{H}, \mathrm{t}, J=5.6 \mathrm{~Hz}, \mathrm{CH}_{2} \mathrm{CH}_{2} \mathrm{CN}\right), 5.66(2 \mathrm{H}, \mathrm{s}$, $\left.\mathrm{NH}_{2}\right) 6.06(1 \mathrm{H}, \mathrm{s}, \mathrm{ArH}-6), 6.82\left(2 \mathrm{H}, \mathrm{d}, J=8.8 \mathrm{~Hz}, \mathrm{ArH}-2^{\prime}, 6^{\prime}\right), 7.10$ (2H, s, ArH-3", $\left.5^{\prime \prime}\right)$, $7.49\left(2 \mathrm{H}, \mathrm{d}, J=8.8 \mathrm{~Hz}, \mathrm{ArH}-3^{\prime}, 5^{\prime}\right), 7.52(1 \mathrm{H}, \mathrm{s}, \mathrm{ArH}-3), 8.84(1 \mathrm{H}, \mathrm{s}, \mathrm{NH}) ; \mathrm{MS} m / z(\%)$ $428.3(\mathrm{M}+1,100)$. 
5-[4"-(2-Cyanoethyl)-2" ,6"-dimethylphenoxy]-N'-(4'-cyanophenyl)-4ethoxymethyl-2-nitroaniline (11 m)—Compound 11e (238 mg, $0.52 \mathrm{mmol})$ in EtOH (25 $\mathrm{mL}$ ) was heated at $100{ }^{\circ} \mathrm{C}$ under microwave irradiation for $20 \mathrm{~min}$. The precipitated solid was collected and dried to produce $203 \mathrm{mg}$ of $\mathbf{1 1 m}$ : $84 \%$ yield; yellow solid; mp 136.3$137.0{ }^{\circ} \mathrm{C} ;{ }^{1} \mathrm{H}$ NMR $\delta 1.34\left(3 \mathrm{H}, \mathrm{t}, J=6.8 \mathrm{~Hz}, \mathrm{CH}_{3}\right), 2.09\left(6 \mathrm{H}, \mathrm{s}, 2 \times \mathrm{CH}_{3}\right), 2.63(2 \mathrm{H}, \mathrm{t}, J=$ $\left.6.8 \mathrm{~Hz}, \mathrm{CH}_{2} \mathrm{CN}\right), 2.90\left(2 \mathrm{H}, \mathrm{t}, J=6.8 \mathrm{~Hz}, \mathrm{ArCH}_{2}\right), 3.71\left(2 \mathrm{H}, \mathrm{q}, J=6.8 \mathrm{~Hz}, \mathrm{OCH}_{2}\right), 4.71(2 \mathrm{H}$, s, $\left.\mathrm{ArCH}_{2} \mathrm{O}\right), 6.28(1 \mathrm{H}, \mathrm{s}, \mathrm{ArH}-6), 7.00$ (2H, s, ArH-3", 5"), $7.06\left(2 \mathrm{H}, \mathrm{d}, J=8.8 \mathrm{~Hz}, \mathrm{ArH}-2^{\prime}\right.$, $\left.6^{\prime}\right), 7.51\left(2 \mathrm{H}, \mathrm{d}, J=8.8 \mathrm{~Hz}, \mathrm{ArH}-3^{\prime}, 5^{\prime}\right), 8.41(1 \mathrm{H}, \mathrm{s}, \mathrm{ArH}-3), 9.73(1 \mathrm{H}, \mathrm{s}, \mathrm{NH}) ; \mathrm{MS} m / z(\%)$ $471.2(\mathrm{M}+1,100)$.

4-Bromo-5-[4"-(2-cyanoethyl)-2" ,6" -dimethylphenoxy]-N1'-(4' -cyanophenyl)-2nitroaniline (11n) and a Byproduct without a 4-Substituent (110)—A mixture of $11 f(27 \mathrm{mg}, 0.06 \mathrm{mmol})$, aq $\mathrm{HBr}(105 \mu \mathrm{L}, 40 \%)$, and aq $\mathrm{NaNO}_{3}(55 \mu \mathrm{L}, 27 \%)$ in $0.5 \mathrm{~mL}$ of THF was stirred at $5{ }^{\circ} \mathrm{C}$ for $1 \mathrm{~h}$, and then $\mathrm{CuBr}(16 \mathrm{mg}, 0.11 \mathrm{mmol})$ and $\mathrm{HBr}(58 \mu \mathrm{L}, 40 \%)$ were added successively while the mixture was being stirred at $5{ }^{\circ} \mathrm{C}$ for an additional $3 \mathrm{~h}$. The solid was removed by filtration and washed with EtOAc several times. The organic phase was separated, and the water phase was extracted with EtOAc. The solvent of the combined organic phase was removed under reduced pressure, and the residue crude product was separated by a flash column chromatograph (gradual elution, $\mathrm{CH}_{2} \mathrm{Cl}_{2}$ /petroleum ether, 0 to $80 \%)$ to produce pure $11 \mathrm{n}(7 \mathrm{mg})$ and $110(9 \mathrm{mg})$ in 23 and $35 \%$ yields, respectively. 11n: mp 180.0-182.0 ${ }^{\circ} \mathrm{C} ;{ }^{1} \mathrm{H}$ NMR $\delta 2.10\left(6 \mathrm{H}, \mathrm{s}, 2 \times \mathrm{CH}_{3}\right), 2.61\left(2 \mathrm{H}, \mathrm{t}, J=7.2 \mathrm{~Hz}, \mathrm{CH}_{2} \mathrm{CN}\right)$, $2.88\left(2 \mathrm{H}, \mathrm{t}, J=7.2 \mathrm{~Hz}, \mathrm{ArCH}_{2}\right), 6.30$ (1H, s, ArH-6), 6.98 (2H, s, ArH-3" , 5"), 6.99 (2H, d, $\left.J=8.8 \mathrm{~Hz}, \mathrm{ArH}-3^{\prime}, 5^{\prime}\right), 7.52\left(2 \mathrm{H}, \mathrm{d}, J=8.8 \mathrm{~Hz}, \mathrm{ArH}-2^{\prime}, 6^{\prime}\right), 8.58(1 \mathrm{H}, \mathrm{s}, \mathrm{ArH}-3), 9.63(1 \mathrm{H}$, $\mathrm{s}, \mathrm{NH}) ; \mathrm{MS} \mathrm{m} / \mathrm{z}(\%) 513.5(\mathrm{M}+\mathrm{Na}, 50), 515.1(\mathrm{M}+2+\mathrm{Na}, 100)$. 110: $\mathrm{mp} 171.3-$ $173.0{ }^{\circ} \mathrm{C} ;{ }^{1} \mathrm{H}$ NMR $\delta 2.11\left(6 \mathrm{H}, \mathrm{s}, 2 \times \mathrm{CH}_{3}\right), 2.64\left(2 \mathrm{H}, \mathrm{t}, J=7.2 \mathrm{~Hz}, \mathrm{CH}_{2} \mathrm{CN}\right), 2.90(2 \mathrm{H}, \mathrm{t}, J$ $\left.=7.2 \mathrm{~Hz}, \mathrm{ArCH}_{2}\right), 6.30(1 \mathrm{H}, \mathrm{dd}, J=9.2 \mathrm{~Hz}, J=2.4 \mathrm{~Hz}, \mathrm{ArH}-4), 6.75(1 \mathrm{H}, \mathrm{d}, J=2.4 \mathrm{~Hz}$, ArH-6), 6.98 (2H, s, ArH-3" ,5") 7.28 (2H, d, $\left.J=8.8 \mathrm{~Hz}, \mathrm{ArH}-2^{\prime}, 6^{\prime}\right), 7.63$ (2H, d, $J=8.8$ $\left.\mathrm{Hz}, \mathrm{ArH}-3^{\prime}, 5^{\prime}\right), 8.20(1 \mathrm{H}, \mathrm{d}, J=9.2 \mathrm{~Hz}, \mathrm{ArH}-3), 9.76(1 \mathrm{H}, \mathrm{s}, \mathrm{NH}) ; \mathrm{MS} m / z(\%) 413.2(\mathrm{M}$ $+1,100)$.

4-Chloro-5-[4"-(2-cyanoethyl)-N1'-(4'-cyanophenyl)-2" ,6"-dimethylphenoxy]-2nitroaniline (11p)—A mixture of $\mathbf{1 0 b}(166 \mathrm{mg}, 0.50 \mathrm{mmol}), 9 \mathbf{a}(90 \mathrm{mg}, 0.60 \mathrm{mmol})$, and $\mathrm{K}_{2} \mathrm{CO}_{3}(138 \mathrm{mg}, 1.0 \mathrm{mmol})$ in DMF $(3 \mathrm{~mL})$ was heated at $110{ }^{\circ} \mathrm{C}$ under microwave irradiation while the mixture was being stirred for $20 \mathrm{~min}$. The reaction was monitored by TLC until it reached completion. The mixture was poured into ice-water, and the solid product was filtered. The product was purified by CombiFlash column chromatography (gradient elution, $\mathrm{CH}_{2} \mathrm{Cl}_{2}$ /petroleum ether, 0 to $75 \%$ ) to give $215 \mathrm{mg}$ of 11p: $55 \%$ yield; orange solid; mp $178-180{ }^{\circ} \mathrm{C} ;{ }^{1} \mathrm{H}$ NMR $\delta 2.12\left(6 \mathrm{H}, \mathrm{s}, 2 \times \mathrm{CH}_{3}\right), 2.61(2 \mathrm{H}, \mathrm{t}, J=7.2 \mathrm{~Hz}$, $\mathrm{CH}_{2} \mathrm{CN}$ ), 2.88 (2H, t, $\left.J=7.2 \mathrm{~Hz}, \mathrm{ArCH}_{2}\right), 6.32$ (1H, s, ArH-6), 6.99 (2H, s, ArH-3", 5"), $7.04\left(2 \mathrm{H}, \mathrm{d}, J=8.8 \mathrm{~Hz}, \mathrm{ArH}-2^{\prime}, 6^{\prime}\right), 7.52\left(2 \mathrm{H}, \mathrm{d}, J=8.8 \mathrm{~Hz}, \mathrm{ArH}-3^{\prime}, 5^{\prime}\right), 8.41(1 \mathrm{H}, \mathrm{s}$, ArH-3), $9.62(1 \mathrm{H}, \mathrm{s}, \mathrm{NH})$; MS m/z (\%) 447.3 (M + 1, 50), 449.3 (M + 3, 24), $469.3(\mathrm{M}+$ $\mathrm{Na}, 100)$. 


\section{Catalytic Hydrogenation To Prepare 4-Substituted 1,5-Diarylbenzene-1,2-diamines (6} series)

A 4-substituted 1,5-diaryl-4-nitrobenzene (5 or 11) in EtOH or EtOAc ( $\sim 20 \mathrm{~mL})$ in the presence of Pd-C (5-10\%, excess) was shaken with $\mathrm{H}_{2}$ under a pressure of 50-55 psi, monitored by TLC for a period of $4-10 \mathrm{~h}$. The solid catalyst was removed by filtration and washed with EtOAc. The solvent of the combined filtrate was removed under reduced pressure, and the residue was purified by flash column chromatography (gradual elution, $\mathrm{MeOH} / \mathrm{CH}_{2} \mathrm{Cl}_{2}, 0$ to $5 \%$ ) to produce corresponding pure 6 series compounds.

5-[4"-(2-Cyanoethyl)-2" ,6" -dimethylphenoxy]-N ${ }^{1}$-(4' -cyanophenyl)-4-(N,Ndimethylcarbamoyl)benzene-1,2-diamine (6a)—Starting with $\mathbf{5 a}(227 \mathrm{mg}, 0.47$ $\mathrm{mmol}$ ) to afford $156 \mathrm{mg}$ of $\mathbf{6 a}: 78 \%$ yield; white solid; $\mathrm{mp} 232.6-233.3{ }^{\circ} \mathrm{C} ;{ }^{1} \mathrm{H}$ NMR $\delta 2.10$ $\left(6 \mathrm{H}, \mathrm{s}, 2 \times \mathrm{CH}_{3}\right), 2.60\left(2 \mathrm{H}, \mathrm{t}, J=7.2 \mathrm{~Hz}, \mathrm{CH}_{2} \mathrm{CN}\right), 2.86\left(2 \mathrm{H}, \mathrm{t}, J=7.2 \mathrm{~Hz}, \mathrm{ArCH}_{2}\right), 3.10$ $\left(3 \mathrm{H}, \mathrm{s}, \mathrm{CH}_{3}\right), 3.16\left(3 \mathrm{H}, \mathrm{s}, \mathrm{CH}_{3}\right), 3.60\left(2 \mathrm{H}, \mathrm{s}, \mathrm{NH}_{2}\right), 5.77(1 \mathrm{H}, \mathrm{s}, \mathrm{NH}), 6.12(1 \mathrm{H}, \mathrm{s}, \mathrm{ArH}-6)$, $6.60\left(2 \mathrm{H}, \mathrm{d}, J=8.8 \mathrm{~Hz}, \mathrm{ArH}-2^{\prime}, 6^{\prime}\right), 6.84(1 \mathrm{H}, \mathrm{s}, \mathrm{ArH}-3), 6.92\left(2 \mathrm{H}, \mathrm{s}, \mathrm{ArH}-3^{\prime \prime}, 5^{\prime \prime}\right), 7.39$ $\left(2 \mathrm{H}, \mathrm{d}, J=8.8 \mathrm{~Hz}, \mathrm{ArH}-3^{\prime}, 5^{\prime}\right)$; MS $m / z(\%) 454.4(\mathrm{M}+1,100)$.

5-[4"-(2-Cyanoethyl)-2", 6 "'-dimethylphenoxy]-N1'-(4'-cyanophenyl)-4-(Nethylcarbamoyl)benzene-1,2-diamine (6b)-Starting with $\mathbf{5 b}(120 \mathrm{mg}, 0.25 \mathrm{mmol})$ to afford $68 \mathrm{mg}$ of $\mathbf{6 b}$ : $60 \%$ yield; white solid; mp 192.1-193.1 ${ }^{\circ} \mathrm{C} ;{ }^{1} \mathrm{H}$ NMR $\delta 1.24(3 \mathrm{H}, \mathrm{t}, J=$ $\left.7.2 \mathrm{~Hz}, \mathrm{CH}_{3}\right), 2.13\left(6 \mathrm{H}, \mathrm{s}, 2 \times \mathrm{CH}_{3}\right), 2.60\left(2 \mathrm{H}, \mathrm{t}, J=7.2 \mathrm{~Hz}, \mathrm{CH}_{2} \mathrm{CN}\right), 2.89(2 \mathrm{H}, \mathrm{t}, J=7.2$ $\left.\mathrm{Hz}, \mathrm{ArCH}_{2}\right), 3.55\left(2 \mathrm{H}, \mathrm{q}, J=7.2 \mathrm{~Hz}, \mathrm{NHCH}_{2}\right), 5.88(1 \mathrm{H}, \mathrm{s}, \mathrm{NH}), 6.21(1 \mathrm{H}, \mathrm{s}, \mathrm{ArH}-6), 6.70$ $\left(2 \mathrm{H}, \mathrm{d}, J=8.8 \mathrm{~Hz}, \mathrm{ArH}-2^{\prime}, 6^{\prime}\right), 6.84(1 \mathrm{H}, \mathrm{s}, \mathrm{ArH}-3), 7.00\left(2 \mathrm{H}, \mathrm{s}, \mathrm{ArH}-3^{\prime \prime}, 5^{\prime \prime}\right), 7.41(2 \mathrm{H}, \mathrm{d}, J$ $\left.=8.8 \mathrm{~Hz}, \mathrm{ArH}-3^{\prime}, 5^{\prime}\right), 7.82(1 \mathrm{H}, \mathrm{s}, \mathrm{ArH}-3), 7.98(1 \mathrm{H}, \mathrm{br}, \mathrm{CONH}) ; \mathrm{MS} \mathrm{m} / \mathrm{z}(\%) 454.4(\mathrm{M}+1$, $100)$.

5-[4"-(2-Cyanoethyl)-2" ,6"-dimethylphenoxy]-N ${ }^{1}$-(4'-cyanophenyl)-4-(Ncyclopropylcarbamoyl)benzene-1,2-diamine (6c)—Starting with 5c (150 mg, 0.30 $\mathrm{mmol}$ ) to afford $115 \mathrm{mg}$ of $\mathbf{6 c}$ : 82\% yield; white solid; mp 221.0-222.7 ${ }^{\circ} \mathrm{C} ;{ }^{1} \mathrm{H}$ NMR $\delta 1.42$ $\left(4 \mathrm{H}, 2 \times \mathrm{CH}_{2}\right), 2.08\left(6 \mathrm{H}, \mathrm{s}, 2 \times \mathrm{CH}_{3}\right), 2.17(1 \mathrm{H}, \mathrm{m}, \mathrm{CH}), 2.60\left(2 \mathrm{H}, \mathrm{t}, J=7.2 \mathrm{~Hz}, \mathrm{CH}_{2} \mathrm{CN}\right)$, $2.86\left(2 \mathrm{H}, \mathrm{t}, J=7.2 \mathrm{~Hz}, \mathrm{ArCH}_{2}\right), 4.66\left(2 \mathrm{H}, \mathrm{s}, \mathrm{NH}_{2}\right), 5.53(1 \mathrm{H}, \mathrm{s}, \mathrm{NH}), 6.02(1 \mathrm{H}, \mathrm{s}, \mathrm{ArH}-6)$, $6.54\left(2 \mathrm{H}, \mathrm{d}, J=8.8 \mathrm{~Hz}, \mathrm{ArH}-2^{\prime}, 6^{\prime}\right), 6.91$ (2H, s, ArH-3", $\left.5^{\prime \prime}\right), 6.97$ (1H, s, ArH-3), 7.39 $\left(2 \mathrm{H}, \mathrm{d}, J=8.8 \mathrm{~Hz}, \mathrm{ArH}-3^{\prime}, 5^{\prime}\right)$; MS m/z (\%) $466.4(\mathrm{M}+1,88), 409.3$ (M - 56, 100).

5-[4"-(2-Cyanoethyl)-2" ,6"-dimethylphenoxy]-N'-(4'-cyanophenyl)-4(isopropylcarbamoyl)benzene-1,2-diamine (6d)—Starting with 11d (200 mg, 0.40) in EtOAc $(25 \mathrm{~mL})$ for $4 \mathrm{~h}$ to afford $150 \mathrm{mg}$ of $\mathbf{6 d}: 80 \%$ yield; $\mathrm{mp} 216.0-218.0{ }^{\circ} \mathrm{C} ;{ }^{1} \mathrm{H}$ NMR $\delta 1.27\left(6 \mathrm{H}, \mathrm{d}, J=6.8 \mathrm{~Hz}, 2 \times \mathrm{CH}_{3}\right), 2.16\left(6 \mathrm{H}, \mathrm{s}, 2 \times \mathrm{ArCH}_{3}\right), 2.64(2 \mathrm{H}, \mathrm{t}, J=7.2 \mathrm{~Hz}$, $\left.\mathrm{CH}_{2} \mathrm{CN}\right), 2.90\left(2 \mathrm{H}, \mathrm{t}, J=7.2 \mathrm{~Hz}, \mathrm{ArCH}_{2}\right), 4.35(1 \mathrm{H}, \mathrm{m}, \mathrm{CH}), 5.85(1 \mathrm{H}, \mathrm{s}, \mathrm{NH}), 6.20(1 \mathrm{H}, \mathrm{s}$, ArH-6), 6.66 (2H, d, $\left.J=8.8 \mathrm{~Hz}, \mathrm{ArH}-2^{\prime}, 6^{\prime}\right), 6.93$ (2H, s, ArH-3" ,5"), 7.42 (2H, d, $J=8.8$ $\left.\mathrm{Hz}, \mathrm{ArH}-3^{\prime}, 5^{\prime}\right), 7.80$ (1H, s, ArH-3), $7.85(1 \mathrm{H}, \mathrm{d}, J=6.8 \mathrm{~Hz}, \mathrm{NH})$; MS m/z (\%) 468.3 (M $+1,100)$.

5-[4"-(2-Cyanoethyl)-2" ,6" -dimethylphenoxy]-N ${ }^{1}$-(4' -cyanophenyl)-4-(N,Ndimethylamino)methylbenzene-1,2-diamine (6e)-Starting with $\mathbf{5 e}(100 \mathrm{mg}, 0.21$ 
mmol) to afford $70 \mathrm{mg}$ of $6 \mathrm{e}: 75 \%$ yield; white solid; mp 142.4-143.9 ${ }^{\circ} \mathrm{C} ;{ }^{1} \mathrm{H}$ NMR $\delta 2.08$ $\left(6 \mathrm{H}, \mathrm{s}, 2 \times \mathrm{CH}_{3}\right), 2.39\left(6 \mathrm{H}, \mathrm{s}, 2 \times \mathrm{CH}_{3}\right), 2.61\left(2 \mathrm{H}, \mathrm{t}, J=7.2 \mathrm{~Hz}, \mathrm{CH}_{2} \mathrm{CN}\right), 2.87(2 \mathrm{H}, \mathrm{t}, J=$ $\left.7.2 \mathrm{~Hz}, \mathrm{ArCH}_{2}\right), 3.67\left(2 \mathrm{H}, \mathrm{s}, \mathrm{ArCH}_{2}\right), 5.51(1 \mathrm{H}, \mathrm{s}, \mathrm{NH}), 6.02(1 \mathrm{H}, \mathrm{s}, \mathrm{ArH}-6), 6.54(2 \mathrm{H}, \mathrm{d}, J$ $\left.=8.8 \mathrm{~Hz}, \mathrm{ArH}-2^{\prime}, 6^{\prime}\right), 6.94\left(2 \mathrm{H}, \mathrm{s}, \mathrm{ArH}-3^{\prime \prime}, 5^{\prime \prime}\right), 7.01(1 \mathrm{H}, \mathrm{s}, \mathrm{ArH}-3), 7.40(2 \mathrm{H}, \mathrm{d}, J=9.2 \mathrm{~Hz}$, ArH- $\left.3^{\prime}, 5^{\prime}\right) ; \mathrm{MS} \mathrm{m} / z(\%) 454.2(\mathrm{M}+1,100)$.

5-[4"-(2-Cyanoethyl)-2", 6" -dimethylphenoxy]-N ${ }^{1}$-(4' -cyanophenyl)-4(cyclopropylamino)methylbenzene-1,2-diamine (6f)—Starting with $\mathbf{5 f}$ (110 mg, 0.23 $\mathrm{mmol}$ ) to afford $60 \mathrm{mg}$ of $6 \mathrm{f}$ : $58 \%$ yield; white solid; mp 106.2-108.0 ${ }^{\circ} \mathrm{C} ;{ }^{1} \mathrm{H}$ NMR $\delta 0.48$ $\left(4 \mathrm{H}, \mathrm{m}, 2 \times \mathrm{CH}_{2}\right), 2.10\left(6 \mathrm{H}, \mathrm{s}, 2 \times \mathrm{CH}_{3}\right), 2.23(1 \mathrm{H}, \mathrm{m}, \mathrm{CH}), 2.14(2 \mathrm{H}, \mathrm{t}, J=7.0 \mathrm{~Hz}$, $\left.\mathrm{CH}_{2} \mathrm{CN}\right), 2.88\left(2 \mathrm{H}, \mathrm{t}, J=7.0 \mathrm{~Hz}, \mathrm{ArCH}_{2}\right), 3.53\left(2 \mathrm{H}, \mathrm{s}, \mathrm{NH}_{2}\right), 3.99\left(2 \mathrm{H}, \mathrm{s}, \mathrm{ArCH}_{2}\right), 5.51(1 \mathrm{H}$, s, NH), 6.02 (1H, s, ArH-6), 6.54 (2H, d, $\left.J=8.8 \mathrm{~Hz}, \mathrm{ArH}-2^{\prime}, 6^{\prime}\right), 6.86$ (1H, s, ArH-3), 6.94 (2H, s, ArH-3" , 5"), 7.40 (2H, d, $\left.J=8.8 \mathrm{~Hz}, \mathrm{ArH}-3^{\prime}, 5^{\prime}\right)$; MS m/z (\%) 354.1 (M - 98, 100), $474.0(\mathrm{M}+\mathrm{Na}, 10)$.

5-[4" -(2-Cyanoethyl)-2",6" -dimethylphenoxy]-N'-(4' -cyanophenyl)-4-(4methylpiperazin-1-yl)methylbenzene-1,2-diamine (6g)—Starting with $\mathbf{5 g}$ (110 mg, $0.21 \mathrm{mmol}$ ) to afford $30 \mathrm{mg}$ of $\mathbf{6 g}$ : $29 \%$ yield; white solid; $\mathrm{mp} 90.9-92.6{ }^{\circ} \mathrm{C} ;{ }^{1} \mathrm{H}$ NMR $\delta$ $2.15\left(6 \mathrm{H}, \mathrm{s}, 2 \times \mathrm{CH}_{3}\right), 2.33\left(3 \mathrm{H}, \mathrm{s}, \mathrm{NCH}_{3}\right), 2.60\left(10 \mathrm{H}, 5 \times \mathrm{CH}_{2}\right), 2.87(2 \mathrm{H}, \mathrm{t}, J=7.2 \mathrm{~Hz}$, $\left.\mathrm{ArCH}_{2}\right), 3.74\left(2 \mathrm{H}, \mathrm{s}, \mathrm{CH}_{2} \mathrm{~N}\right), 5.52(1 \mathrm{H}, \mathrm{s}, \mathrm{NH}), 6.02(1 \mathrm{H}, \mathrm{s}, \mathrm{ArH}-6), 6.55(2 \mathrm{H}, \mathrm{d}, J=8.8 \mathrm{~Hz}$, ArH-2' $\left.6^{\prime}\right), 6.91$ (2H, s, ArH-3" ,5"), 6.97 (1H, s, ArH-3), 7.40 (2H, d, $J=8.8 \mathrm{~Hz}, \mathrm{ArH}-3^{\prime}$, $\left.5^{\prime}\right)$; MS m/z (\%) 495.6 (M + 1, 4.9), 395 (M - 99, 100).

4-Acetoxymethyl-5-[4" -(2-cyanoethyl)-2",6" -dimethylphenoxy]-N1-(4'cyanophenyl)benzene-1,2-diamine (6h)-Starting with $\mathbf{5 h}(80 \mathrm{mg}, 0.17 \mathrm{mmol})$ to afford $30 \mathrm{mg}$ of $\mathbf{6 h}$ : $40 \%$ yield; white solid; $\mathrm{mp} 164.1-165.7{ }^{\circ} \mathrm{C} ;{ }^{1} \mathrm{H}$ NMR (DMSO- $d_{6}$ ) $\delta$ $2.04\left(6 \mathrm{H}, \mathrm{s}, 2 \times \mathrm{CH}_{3}\right), 2.09\left(3 \mathrm{H}, \mathrm{s}, \mathrm{COCH}_{3}\right), 2.78\left(4 \mathrm{H}, \mathrm{s}, 2 \times \mathrm{CH}_{2}\right), 4.58\left(2 \mathrm{H}, \mathrm{s}, \mathrm{NH}_{2}\right), 5.19$ $\left(2 \mathrm{H}, \mathrm{s}, \mathrm{CH}_{2} \mathrm{O}\right), 5.90(1 \mathrm{H}, \mathrm{s}, \mathrm{NH}), 6.54\left(2 \mathrm{H}, \mathrm{d}, J=8.8 \mathrm{~Hz}, \mathrm{ArH}-2^{\prime}, 6^{\prime}\right), 6.87$ (1H, s, ArH-6), $7.04\left(2 \mathrm{H}, \mathrm{s}, \mathrm{ArH}-3^{\prime \prime}, 5^{\prime \prime}\right), 7.45$ (2H, d, $\left.J=8.8 \mathrm{~Hz}, \mathrm{ArH}-3^{\prime}, 5^{\prime}\right), 8.08$ (1H, s, ArH-3); MS m/z (\%) $455.3(\mathrm{M}+1,17), 395.2(\mathrm{M}-59,100)$.

\section{5-[4"-(2-Cyanoethyl)-2",6"-dimethylphenoxy]-N1'-(4'-cyanophenyl)-4-} [(cyclopropylcarbonyl)oxy]methylbenzene-1,2-diamine (6i)-Starting with 5i (180 $\mathrm{mg}, 0.35 \mathrm{mmol})$ to afford $35 \mathrm{mg}$ of $\mathbf{6 i :} 21 \%$ yield; white solid; $\mathrm{mp} 188.2-189.6{ }^{\circ} \mathrm{C}$; ${ }^{1} \mathrm{H}$ NMR $\delta 0.90\left(2 \mathrm{H}, \mathrm{m}, \mathrm{CH}_{2}\right), 1.06\left(2 \mathrm{H}, \mathrm{m}, \mathrm{CH}_{2}\right), 1.70(1 \mathrm{H}, \mathrm{m}, \mathrm{CH}), 2.10\left(6 \mathrm{H}, \mathrm{s}, 2 \times \mathrm{CH}_{3}\right), 2.61$ $\left(2 \mathrm{H}, \mathrm{t}, J=6.8 \mathrm{~Hz}, \mathrm{CH}_{2} \mathrm{CN}\right), 2.87\left(2 \mathrm{H}, \mathrm{t}, J=6.8 \mathrm{~Hz}, \mathrm{ArCH}_{2}\right), 3.48\left(2 \mathrm{H}, \mathrm{s}, \mathrm{NH}_{2}\right), 5.31(2 \mathrm{H}, \mathrm{s}$, $\left.\mathrm{CH}_{2} \mathrm{O}\right), 5.56(1 \mathrm{H}, \mathrm{s}, \mathrm{NH}), 6.06(1 \mathrm{H}, \mathrm{s}, \mathrm{ArH}-6), 6.58\left(2 \mathrm{H}, \mathrm{d}, J=8.8 \mathrm{~Hz}, \mathrm{ArH}-2^{\prime}, 6^{\prime}\right), 6.92$ $\left(3 \mathrm{H}, \mathrm{s}, \mathrm{ArH}-3,3^{\prime \prime}, 5^{\prime \prime}\right), 7.41$ (2H, d, $\left.J=8.8 \mathrm{~Hz}, \mathrm{ArH}-3^{\prime}, 5^{\prime}\right) ; \mathrm{MS} \mathrm{m} / \mathrm{z}(\%) 481.5(\mathrm{M}+1,33)$, $395.2(\mathrm{M}-85,100)$.

\section{5-[4"-(2-Cyanoethyl)-2",6"-dimethylphenoxy]-N ${ }^{1}$-(4"-cyanophenyl)-4-(N-} methyl carbamate)methyl-2-nitroaniline (6j)-Starting with $\mathbf{5 j}$ (150 mg, $0.30 \mathrm{mmol}$ ) to afford $67 \mathrm{mg}$ of $\mathbf{6 j}$ : $48 \%$ yield; white solid; mp 203-204 ${ }^{\circ} \mathrm{C} ;{ }^{1} \mathrm{H}$ NMR $\delta 2.09(6 \mathrm{H}, \mathrm{s}, 2 \times$ $\left.\mathrm{CH}_{3}\right), 2.61\left(2 \mathrm{H}, \mathrm{t}, J=6.8 \mathrm{~Hz}, \mathrm{CH}_{2} \mathrm{CN}\right), 2.86\left(5 \mathrm{H}, \mathrm{m}, \mathrm{ArCH}_{2}\right.$ and $\left.\mathrm{NCH}_{3}\right), 3.48\left(2 \mathrm{H}, \mathrm{s}, \mathrm{NH}_{2}\right)$, $4.71(1 \mathrm{H}, \mathrm{s}, \mathrm{CONH}), 5.31\left(2 \mathrm{H}, \mathrm{s}, \mathrm{CH}_{2} \mathrm{O}\right), 5.56(1 \mathrm{H}, \mathrm{s}, \mathrm{NH}), 6.05(1 \mathrm{H}, \mathrm{s}, \mathrm{ArH}-6), 6.56(2 \mathrm{H}$, 
d, $\left.J=8.8 \mathrm{~Hz}, \mathrm{ArH}-2^{\prime}, 6^{\prime}\right), 6.92\left(3 \mathrm{H}, \mathrm{s}, \mathrm{ArH}-3^{\prime \prime}, 5^{\prime \prime}\right), 6.93(1 \mathrm{H}, \mathrm{s}, \mathrm{ArH}-3) 7.40$ (2H, d, $J=8.8$ $\left.\mathrm{Hz}, \mathrm{ArH}-3^{\prime}, 5^{\prime}\right) ; \mathrm{MS} \mathrm{m} / \mathrm{z}(\%) 470.1(\mathrm{M}+1,22), 395.2(\mathrm{M}-74,100)$.

5-[4"-(2-Cyanoethyl)-2" ,6"-dimethylphenoxy]-N'-(4'-cyanophenyl)-4methoxymethylbenzene-1,2-diamine (6k)—Starting with 5k (150 mg, $0.33 \mathrm{mmol})$ to afford $110 \mathrm{mg}$ of $\mathbf{6 k}$ : $79 \%$ yield; white solid; mp 103.6-104.8 ${ }^{\circ} \mathrm{C} ;{ }^{1} \mathrm{H}$ NMR $\delta 2.09(6 \mathrm{H}, \mathrm{s}, 2$ $\left.\times \mathrm{CH}_{3}\right), 2.61\left(2 \mathrm{H}, \mathrm{t}, J=7.2 \mathrm{~Hz}, \mathrm{CH}_{2} \mathrm{CN}\right), 2.87\left(2 \mathrm{H}, \mathrm{t}, J=7.2 \mathrm{~Hz}, \mathrm{ArCH}_{2}\right), 3.52(3 \mathrm{H}, \mathrm{s}$, $\left.\mathrm{OCH}_{3}\right), 4.67\left(2 \mathrm{H}, \mathrm{s}, \mathrm{CH}_{2} \mathrm{O}\right), 5.56(1 \mathrm{H}, \mathrm{s}, \mathrm{NH}), 6.03(1 \mathrm{H}, \mathrm{s}, \mathrm{ArH}-6), 6.55(2 \mathrm{H}, \mathrm{d}, J=8.8 \mathrm{~Hz}$, ArH-2', 6' $), 6.92$ (2H, s, ArH-3", $\left.5^{\prime \prime}\right), 6.99$ (1H, s, ArH-3), 7.39 (2H, d, $J=8.8 \mathrm{~Hz}, \mathrm{ArH}-3^{\prime}$, $\left.5^{\prime}\right) ; \mathrm{MS} m / z(\%) 427.3(\mathrm{M}+1,100)$.

\section{5-[4" -(2-Cyanoethyl)-2",6"-dimethylphenoxy]-N1-(4'-cyanophenyl)-4-} (ethoxymethyl)benzene-1,2-diamine (6m)-Starting with $11 \mathrm{e}(180 \mathrm{mg}, 0.38 \mathrm{mmol})$ in EtOAc $(20 \mathrm{~mL})$ for $4 \mathrm{~h}$ to afford $97 \mathrm{mg}$ of $\mathbf{6 m}$ : $58 \%$ yield; white solid; $\mathrm{mp} 135.9-$ $137.2{ }^{\circ} \mathrm{C} ;{ }^{1} \mathrm{H}$ NMR $\delta 1.32\left(3 \mathrm{H}, \mathrm{t}, J=7.2 \mathrm{~Hz}, \mathrm{CH}_{3}\right), 2.09\left(6 \mathrm{H}, \mathrm{s}, 2 \times \mathrm{CH}_{3}\right), 2.61(2 \mathrm{H}, \mathrm{t}, J=$ $\left.7.2 \mathrm{~Hz}, \mathrm{CH}_{2} \mathrm{CN}\right), 2.87\left(2 \mathrm{H}, \mathrm{t}, J=7.2 \mathrm{~Hz}, \mathrm{ArCH}_{2}\right), 3.70\left(2 \mathrm{H}, \mathrm{q}, J=7.2 \mathrm{~Hz}, \mathrm{OCH}_{2}\right), 4.71(2 \mathrm{H}$, s, $\left.\mathrm{ArCH}_{2} \mathrm{O}\right), 5.54(1 \mathrm{H}, \mathrm{s}, \mathrm{NH}), 6.02(1 \mathrm{H}, \mathrm{s}, \mathrm{ArH}-6), 6.54\left(2 \mathrm{H}, \mathrm{d}, J=8.8 \mathrm{~Hz}, \mathrm{ArH}-2^{\prime}, 6^{\prime}\right)$, $6.92\left(2 \mathrm{H}, \mathrm{s}, \mathrm{ArH}-3^{\prime \prime}, 5^{\prime \prime}\right), 7.00$ (1H, s, ArH-3), 7.39 (2H, d, $\left.J=8.8 \mathrm{~Hz}, \mathrm{ArH}-3^{\prime}, 5^{\prime}\right) ; \mathrm{MS} \mathrm{m} / \mathrm{z}$ (\%) $441.4(\mathrm{M}+1,100)$.

\section{4-Bromo-5-[4" -(2-cyanoethyl)-2",6" -dimethylphenoxy]-N1'-(4'-} cyanophenyl)benzene-1,2-diamine (6n) and 5-[4"-(2-Cyanoethyl)-2",6"dimethylphenoxy]-N ${ }^{\mathbf{1}}$-(4'-cyanophenyl)benzene-1,2-diamine (60)-The mixture of $11 \mathrm{n}$ and $11 \mathrm{o}(60 \mathrm{mg})$, Fe powder (22 $\mathrm{mg}, 0.39 \mathrm{mmol})$, and $\mathrm{NH}_{4} \mathrm{Cl}(70 \mathrm{mg}, 1.3 \mathrm{mmol})$ in a mixed solvent of THF, $\mathrm{MeOH}$, and $\mathrm{H}_{2} \mathrm{O}$ [24 mL, 1:1:1 (v/v/v)] was heated to reflux for $3 \mathrm{~h}$. The solid was filtered out and washed with EtOAc. The filtrate was extracted with EtOAc several times. After removal of organic solvent under reduced pressure, the residue was separated by preparative HPLC using a C18 column chromatograph (gradient elution, methanol/water, 55 to $75 \%)$ to produce pure $\mathbf{6 n}(17 \mathrm{mg})$ and $\mathbf{6 o}(18 \mathrm{mg})$. $\mathbf{6 n}$ : white solid; mp 199.5-201.3 ${ }^{\circ} \mathrm{C} ;{ }^{1} \mathrm{H}$ NMR $\delta 2.12\left(6 \mathrm{H}, \mathrm{s}, 2 \times \mathrm{CH}_{3}\right), 2.61\left(2 \mathrm{H}, \mathrm{t}, J=7.2 \mathrm{~Hz}, \mathrm{CH}_{2} \mathrm{CN}\right), 2.87$ $\left(2 \mathrm{H}, \mathrm{t}, J=7.2 \mathrm{~Hz}, \mathrm{ArCH}_{2}\right), 3.54\left(2 \mathrm{H}, \mathrm{s}, \mathrm{NH}_{2}\right), 5.65(1 \mathrm{H}, \mathrm{s}, \mathrm{NH}), 6.12(1 \mathrm{H}, \mathrm{s}, \mathrm{ArH}-6), 6.56$ $\left(2 \mathrm{H}, \mathrm{d}, J=8.4 \mathrm{~Hz}, \mathrm{ArH}-2^{\prime}, 6^{\prime}\right), 6.93$ (2H, s, ArH-3", $\left.5^{\prime \prime}\right), 7.12(1 \mathrm{H}, \mathrm{s}, \mathrm{ArH}-3), 7.42$ (2H, d, $J$ $\left.=8.4 \mathrm{~Hz}, \mathrm{ArH}-3^{\prime}, 5^{\prime}\right) ; \mathrm{MS} \mathrm{m} / \mathrm{z}(\%) 461.0(\mathrm{M}+1,100), 463.0(\mathrm{M}+3,100)$. 6o: white solid; mp 174.5-176.3 ${ }^{\circ} \mathrm{C} ;{ }^{1} \mathrm{H}$ NMR $\delta 2.12\left(6 \mathrm{H}, \mathrm{s}, 2 \times \mathrm{CH}_{3}\right), 2.63\left(2 \mathrm{H}, \mathrm{t}, J=7.2 \mathrm{~Hz}, \mathrm{CH}_{2} \mathrm{CN}\right)$, $2.89\left(2 \mathrm{H}, \mathrm{t}, J=7.2 \mathrm{~Hz}, \mathrm{ArCH}_{2}\right), 5.65(1 \mathrm{H}, \mathrm{s}, \mathrm{NH}), 6.53(1 \mathrm{H}, \mathrm{dd}, J=8.8 \mathrm{~Hz}, J=2.8 \mathrm{~Hz}$, ArH-4), 6.56 (1H, d, $J=2.8 \mathrm{~Hz}, \mathrm{ArH}-6), 6.69$ (2H, d, $\left.J=8.8 \mathrm{~Hz}, \mathrm{ArH}-2^{\prime}, 6^{\prime}\right), 6.73(1 \mathrm{H}, \mathrm{d}, J$ $=9.2 \mathrm{~Hz}, \mathrm{ArH}-3), 6.93\left(2 \mathrm{H}, \mathrm{s}, \mathrm{ArH}-3^{\prime \prime}, 5^{\prime \prime}\right), 7.46\left(2 \mathrm{H}, \mathrm{d}, J=8.8 \mathrm{~Hz}, \mathrm{ArH}-3^{\prime}, 5^{\prime}\right) ; \mathrm{MS} \mathrm{m} / z$ (\%) $383.3(\mathrm{M}+1,41.4), 209.0(\mathrm{M}-173,100)$.

\section{4-Chloro-5-[4"-(2-cyanoethyl)-2",6" -dimethylphenoxy]-N ${ }^{1}-\left(4^{\prime}-\right.$} cyanophenyl)benzene-1,2-diamine (6p)-Reduction followed the same preparation that was used for $\mathbf{6 n}$. The mixture of $\mathbf{1 1 p}$ (115 $\mathrm{mg}, 0.26 \mathrm{mmol}$ ), iron powder (43 $\mathrm{mg}, 0.77$ $\mathrm{mmol}$ ), and $\mathrm{NH}_{4} \mathrm{Cl}\left(139 \mathrm{mg}, 2.60 \mathrm{mmol}\right.$ ) in a mixed solvent of THF, $\mathrm{MeOH}$, and $\mathrm{H}_{2} \mathrm{O}$ [24 $\mathrm{mL}, 1: 1: 1(\mathrm{v} / \mathrm{v} / \mathrm{v})]$ was heated to reflux for $3 \mathrm{~h}$. After removal of the inorganic solid and organic solvent, the crude product was separated by preparative HPLC using a C18 column 
chromatograph (gradient elution, methanol/water, 55 to $75 \%$ ) to afford $70 \mathrm{mg}$ of $\mathbf{6 p}$ : white solid; mp 182.1-183.6 ${ }^{\circ} \mathrm{C} ;{ }^{1} \mathrm{H}$ NMR $\delta 2.12\left(6 \mathrm{H}, \mathrm{s}, 2 \times \mathrm{CH}_{3}\right), 2.61(2 \mathrm{H}, \mathrm{t}, J=7.2 \mathrm{~Hz}$, $\left.\mathrm{CH}_{2} \mathrm{CN}\right), 2.87\left(2 \mathrm{H}, \mathrm{t}, J=7.2 \mathrm{~Hz}, \mathrm{ArCH}_{2}\right), 3.55\left(2 \mathrm{H}, \mathrm{s}, \mathrm{NH}_{2}\right), 5.50(1 \mathrm{H}, \mathrm{s}, \mathrm{NH}), 6.14(1 \mathrm{H}, \mathrm{s}$, ArH-6), 6.55 (2H, d, $\left.J=8.8 \mathrm{~Hz}, \mathrm{ArH}-2^{\prime}, 6^{\prime}\right), 6.92$ (2H, s, ArH-3", 5"), $6.95(1 \mathrm{H}, \mathrm{s}, \mathrm{ArH}-3)$, $7.41\left(2 \mathrm{H}, \mathrm{d}, J=8.8 \mathrm{~Hz}, \mathrm{ArH}-3^{\prime}, 5^{\prime}\right) ; \mathrm{MS} \mathrm{m} / \mathrm{z}(\%) 417.2(\mathrm{M}+1,100)$.

5-[4" -(2-Cyanoethyl)-2",6"-dimethoxyphenoxy]-N1'-(4'-cyanophenyl)-4methoxycarbonyl-2-nitroaniline (13a)-The preparation was the same as that of 11a. Starting with 10a $(1 \mathrm{~g}, 3.00 \mathrm{mmol})$ and $9 \mathbf{b}(750 \mathrm{mg}, 3.60 \mathrm{mmol})$ in DMF $(20 \mathrm{~mL})$ in the presence of $\mathrm{K}_{2} \mathrm{CO}_{3}(828 \mathrm{mg}, 6.00 \mathrm{mmol})$ to afford $1.2 \mathrm{~g}$ of 13a: $80 \%$ yield; yellow solid; $\mathrm{mp}$ 172.3-174.0 ${ }^{\circ} \mathrm{C} ;{ }^{1} \mathrm{H}$ NMR $\delta 2.64\left(2 \mathrm{H}, \mathrm{t}, J=7.2 \mathrm{~Hz}, \mathrm{CH}_{2} \mathrm{CN}\right), 2.92(2 \mathrm{H}, \mathrm{t}, J=7.2 \mathrm{~Hz}$, $\left.\mathrm{ArCH}_{2}\right), 3.80\left(6 \mathrm{H}, \mathrm{s}, 2 \times \mathrm{OCH}_{3}\right), 3.94\left(3 \mathrm{H}, \mathrm{d}, J=4.8 \mathrm{~Hz}, \mathrm{OCH}_{3}\right), 6.47(1 \mathrm{H}, \mathrm{s}, \mathrm{ArH}-6), 6.51$ $\left(2 \mathrm{H}, \mathrm{s}, \mathrm{ArH}-3^{\prime \prime}, 5^{\prime \prime}\right), 7.15\left(2 \mathrm{H}, \mathrm{d}, J=8.8 \mathrm{~Hz}, \mathrm{ArH}-2^{\prime}, 6^{\prime}\right), 7.54\left(2 \mathrm{H}, \mathrm{d}, J=8.8 \mathrm{~Hz}, \mathrm{ArH}-3^{\prime}\right.$, $\left.5^{\prime}\right), 8.98(1 \mathrm{H}, \mathrm{s}, \mathrm{ArH}-3), 9.80(1 \mathrm{H}, \mathrm{s}, \mathrm{NH})$; MS m/z (\%) $503.1(\mathrm{M}+1,100)$.

5-[2"-Bromo-4" -(2-cyanoethyl)-6" -methoxyphenoxy]-N1'-(4'-cya-nophenyl)-4methoxycarbonyl-2-nitroaniline (14a)-The preparation was the same as that of 11a. Starting with 10a (455 mg, $1.37 \mathrm{mmol})$, 9c (264 mg, $1.15 \mathrm{mmol})$, and $\mathrm{K}_{2} \mathrm{CO}_{3}(414 \mathrm{mg}, 3$ $\mathrm{mmol}$ ) in DMF (10 mL) to afford $340 \mathrm{mg}$ of 14a: $60 \%$ yield; yellow solid; mp 174.2 $175.2{ }^{\circ} \mathrm{C} ;{ }^{1} \mathrm{H}$ NMR $\delta 2.64\left(2 \mathrm{H}, \mathrm{t}, J=6.8 \mathrm{~Hz}, \mathrm{CH}_{2} \mathrm{CN}\right), 2.92\left(2 \mathrm{H}, \mathrm{t}, J=6.8 \mathrm{~Hz}, \mathrm{ArCH}_{2}\right)$, $3.80\left(3 \mathrm{H}, \mathrm{s}, \mathrm{OCH}_{3}\right), 3.96\left(3 \mathrm{H}, \mathrm{s}, \mathrm{OCH}_{3}\right), 6.35(1 \mathrm{H}, \mathrm{s}, \mathrm{ArH}-6), 6.89(1 \mathrm{H}, \mathrm{d}, J=2.4 \mathrm{~Hz}$, ArH-5"), 7.10 (1H, d, $\left.J=2.4 \mathrm{~Hz}, \mathrm{ArH}-3^{\prime \prime}\right), 7.20\left(2 \mathrm{H}, \mathrm{d}, J=8.8 \mathrm{~Hz}, \mathrm{ArH}-2^{\prime}, 6^{\prime}\right), 7.57(2 \mathrm{H}$, d, $\left.J=8.8 \mathrm{~Hz}, \mathrm{ArH}-3^{\prime}, 5^{\prime}\right), 9.00(1 \mathrm{H}, \mathrm{s}, \mathrm{ArH}-3), 9.81(1 \mathrm{H}, \mathrm{s}, \mathrm{NH})$; MS $m / z(\%) 551.0(\mathrm{M}+1$, 34), $553.0(\mathrm{M}+3,36), 440.2(\mathrm{M}-110,100)$.

\section{5-[4"-(2-Cyanoethyl)-2",6"-dimethoxyphenoxy]-N1'-(4'-cyanophenyl)-4-} methylcarbamoyl-2-nitroaniline (13b)-A mixture of 13a (100 mg, $0.20 \mathrm{mmol})$ and an aqueous $\mathrm{CH}_{3} \mathrm{NH}_{2}$ solution (25-30\%, $1 \mathrm{~mL}$, excess) in THF ( $3 \mathrm{~mL}$ ) was stirred vigorously at $40{ }^{\circ} \mathrm{C}$ for $4 \mathrm{~h}$. The mixture was poured into ice-water, and the $\mathrm{pH}$ was adjusted to 4 with aq $\mathrm{HCl}(5 \%)$. The precipitated yellow solid was collected and purified by CombiFlash column chromatography (gradient elution, EtOAc/petroleum ether, 60 to 100\%) to produce $57 \mathrm{mg}$ of 13b: 57\% yield; yellow solid; mp 202-203 ${ }^{\circ} \mathrm{C} ;{ }^{1} \mathrm{H}$ NMR $\delta 2.70\left(2 \mathrm{H}, \mathrm{t}, J=7.2 \mathrm{~Hz}, \mathrm{CH}_{2} \mathrm{CN}\right)$, $2.98\left(2 \mathrm{H}, \mathrm{t}, J=7.2 \mathrm{~Hz}, \mathrm{ArCH}_{2}\right), 3.06\left(3 \mathrm{H}, \mathrm{d}, J=4.8 \mathrm{~Hz}, \mathrm{NCH}_{3}\right), 3.84\left(6 \mathrm{H}, \mathrm{s}, 2 \times \mathrm{OCH}_{3}\right)$, $6.51(1 \mathrm{H}, \mathrm{s}, \mathrm{ArH}-6), 6.56\left(2 \mathrm{H}, \mathrm{s}, \mathrm{ArH}-3^{\prime \prime}, 5^{\prime \prime}\right), 7.17$ (2H, d, $\left.J=8.8 \mathrm{~Hz}, \mathrm{ArH}-2^{\prime}, 6^{\prime}\right), 7.56$ $\left(2 \mathrm{H}, \mathrm{d}, J=8.8 \mathrm{~Hz}, \mathrm{ArH}-3^{\prime}, 5^{\prime}\right), 7.69(1 \mathrm{H}, \mathrm{d}, J=4.8 \mathrm{~Hz}, \mathrm{CONH}), 9.19$ (1H, s, ArH-3), 9.76 $(1 \mathrm{H}, \mathrm{s}, \mathrm{NH}) ; \mathrm{MS} \mathrm{m} / z(\%) 502.1(\mathrm{M}+1,100)$.

\section{5-[2"-Bromo-4" -(2-cyanoethyl)-6"-methoxyphenoxy]-N1'-(4'-cya-nophenyl)-4- methylcarbamoyl-2-nitroaniline (14b)-The preparation was the same as that of $\mathbf{1 3 b}$. Starting with 14a ( $340 \mathrm{mg}, 0.62 \mathrm{mmol}$ ) and an aqueous $\mathrm{CH}_{3} \mathrm{NH}_{2}$ solution (25-30\%, excess) to afford $105 \mathrm{mg}$ of $\mathbf{1 4 b}$ : $31 \%$ yield; yellow solid; mp $225-227{ }^{\circ} \mathrm{C} ;{ }^{1} \mathrm{H}$ NMR $\delta 2.68(2 \mathrm{H}, \mathrm{t}, J$ $\left.=6.8 \mathrm{~Hz}, \mathrm{CH}_{2} \mathrm{CN}\right), 2.95\left(2 \mathrm{H}, \mathrm{t}, J=6.8 \mathrm{~Hz}, \mathrm{ArCH}_{2}\right), 3.06\left(3 \mathrm{H}, \mathrm{d}, J=4.8 \mathrm{~Hz}, \mathrm{NCH}_{3}\right), 3.83$ $\left(3 \mathrm{H}, \mathrm{s}, \mathrm{OCH}_{3}\right), 6.38(1 \mathrm{H}, \mathrm{s}, \mathrm{ArH}-6), 6.88\left(1 \mathrm{H}, \mathrm{d}, J=2.0 \mathrm{~Hz}, \mathrm{ArH}-5^{\prime \prime}\right), 7.13(1 \mathrm{H}, \mathrm{d}, J=2.0$ Hz, ArH-3") $7.18\left(2 \mathrm{H}, \mathrm{d}, J=8.8 \mathrm{~Hz}, \mathrm{ArH}-2^{\prime}, 6^{\prime}\right), 7.47(1 \mathrm{H}, \mathrm{d}, J=4.8 \mathrm{~Hz}, \mathrm{CONH}), 7.56$}


$\left(2 \mathrm{H}, \mathrm{d}, J=8.8 \mathrm{~Hz}, \mathrm{ArH}-3^{\prime}, 5^{\prime}\right), 9.21(1 \mathrm{H}, \mathrm{s}, \mathrm{ArH}-3), 9.73(1 \mathrm{H}, \mathrm{s}, \mathrm{NH})$; MS $m / z(\%) 550.0$ $(\mathrm{M}+1,78), 552.0(\mathrm{M}+3,100)$.

5-[4"-(2-Cyanoethyl)-2", 6"-dimethoxyphenoxy]-N1'-(4'-cyanophenyl)-4methoxycarbonylbenzene-1,2-diamine (13c)-The catalytic hydrogenation was the same as the preparation of 6a. Starting with $\mathbf{1 3 a}(200 \mathrm{mg}, 0.40 \mathrm{mmol})$ in EtOAc $(20 \mathrm{~mL})$ for $4 \mathrm{~h}$ to produce $140 \mathrm{mg}$ of 13c: $74 \%$ yield; white solid; mp $176.6-178.3{ }^{\circ} \mathrm{C} ;{ }^{1} \mathrm{H}$ NMR $\delta 2.60$ $\left(2 \mathrm{H}, \mathrm{t}, J=7.2 \mathrm{~Hz}, \mathrm{CH}_{2} \mathrm{CN}\right), 2.90\left(2 \mathrm{H}, \mathrm{t}, J=7.2 \mathrm{~Hz}, \mathrm{ArCH}_{2}\right), 3.75\left(6 \mathrm{H}, \mathrm{s}, 2 \times \mathrm{OCH}_{3}\right), 3.89$ $\left(3 \mathrm{H}, \mathrm{s}, \mathrm{OCH}_{3}\right), 5.87(1 \mathrm{H}, \mathrm{s}, \mathrm{NH}), 6.47\left(3 \mathrm{H}, \mathrm{s}, \mathrm{ArH}-6,3^{\prime}, 5^{\prime}\right), 6.73\left(2 \mathrm{H}, \mathrm{d}, J=8.8 \mathrm{~Hz}, \mathrm{ArH}-2^{\prime}\right.$, $\left.6^{\prime}\right), 7.40(1 \mathrm{H}, \mathrm{s}, \mathrm{ArH}-3), 7.41\left(2 \mathrm{H}, \mathrm{d}, J=8.8 \mathrm{~Hz}, \mathrm{ArH}-3^{\prime}, 5^{\prime}\right) ; \mathrm{MS} \mathrm{m} / \mathrm{z}(\%) 473.2(\mathrm{M}+1$, 33.6), 441.3 (M - 31, 100).

5-[4"-(2-Cyanoethyl)-2", 6"-dimethoxyphenoxy]-N1'-(4' -cyanophenyl)-4methylcarbamoylbenzene-1,2-diamine (13d)-The catalytic hydrogenation was the same as the preparation of $\mathbf{6 a}$. Starting with $\mathbf{1 3 b}(170 \mathrm{mg}, 0.34 \mathrm{mmol})$ to afford $100 \mathrm{mg}$ of 13d: $63 \%$ yield; white solid; mp 240.3-241.9 ${ }^{\circ} \mathrm{C} ;{ }^{1} \mathrm{H}$ NMR $\delta 2.67(2 \mathrm{H}, \mathrm{t}, J=7.2 \mathrm{~Hz}$, $\left.\mathrm{CH}_{2} \mathrm{CN}\right), 2.95\left(2 \mathrm{H}, \mathrm{t}, J=7.2 \mathrm{~Hz}, \mathrm{ArCH}_{2}\right), 3.02\left(3 \mathrm{H}, \mathrm{d}, J=4.4 \mathrm{~Hz}, \mathrm{NCH}_{3}\right), 3.49(2 \mathrm{H}, \mathrm{s}$, $\left.\mathrm{NH}_{2}\right), 3.80\left(6 \mathrm{H}, \mathrm{s}, 2 \times \mathrm{OCH}_{3}\right), 5.89(1 \mathrm{H}, \mathrm{s}, \mathrm{NH}), 6.45(1 \mathrm{H}, \mathrm{s}, \mathrm{ArH}-6), 6.52\left(2 \mathrm{H}, \mathrm{s}, \mathrm{ArH}-3^{\prime \prime}\right.$, $\left.5^{\prime \prime}\right), 6.74\left(2 \mathrm{H}, \mathrm{d}, J=8.8 \mathrm{~Hz}, \mathrm{ArH}-2^{\prime}, 6^{\prime}\right), 7.42\left(2 \mathrm{H}, \mathrm{d}, J=8.8 \mathrm{~Hz}, \mathrm{ArH}-3^{\prime}, 5^{\prime}\right), 7.64(1 \mathrm{H}, \mathrm{s}$, ArH-3), $8.00(1 \mathrm{H}, \mathrm{d}, J=4.4 \mathrm{~Hz}, \mathrm{CONH})$; MS $m / z(\%) 472.2(\mathrm{M}+1,100)$.

5-[2"-Bromo-4" -(2-cyanoethyl)-6"-methoxyphenoxy]-N1'-(4' -cya-nophenyl)-4methoxycarbonylbenzene-1,2-diamine (14c)—Reduction with $\mathrm{Fe} / \mathrm{NH}_{4} \mathrm{Cl}$ was the same as that used in the preparation of $\mathbf{6 p}$. Starting with 14a (crude, $250 \mathrm{mg}, 0.48 \mathrm{mmol}$ ), iron $(269 \mathrm{mg}, 4.8 \mathrm{mmol})$, and $\mathrm{NH}_{4} \mathrm{Cl}(257 \mathrm{mg}, 4.8 \mathrm{mmol})$ to afford $70 \mathrm{mg}$ of $\mathbf{1 4 c}$ : white solid; mp 196.6-197.1 ${ }^{\circ} \mathrm{C} ;{ }^{1} \mathrm{H}$ NMR $\delta 2.64\left(2 \mathrm{H}, \mathrm{t}, J=7.2 \mathrm{~Hz}, \mathrm{CH}_{2} \mathrm{CN}\right), 2.91(2 \mathrm{H}, \mathrm{t}, J=7.2$ $\left.\mathrm{Hz}, \mathrm{ArCH}_{2}\right), 3.44\left(2 \mathrm{H}, \mathrm{s}, \mathrm{NH}_{2}\right), 3.77\left(3 \mathrm{H}, \mathrm{s}, \mathrm{OCH}_{3}\right), 3.92\left(3 \mathrm{H}, \mathrm{s}, 2 \times \mathrm{CH}_{3}\right), 5.87(1 \mathrm{H}, \mathrm{s}$, $\mathrm{NH}), 6.38(1 \mathrm{H}, \mathrm{s}, \mathrm{ArH}-6), 6.76\left(2 \mathrm{H}, \mathrm{d}, J=8.8 \mathrm{~Hz}, \mathrm{ArH}-2^{\prime}, 6^{\prime}\right), 6.81(1 \mathrm{H}, \mathrm{d}, J=2 \mathrm{~Hz}$, ArH-5"), 6.95 (1H, s, ArH-3), 7.06 (1H, d, $\left.J=2 \mathrm{~Hz}, \mathrm{ArH}-3^{\prime \prime}\right), 7.43(2 \mathrm{H}, \mathrm{d}, J=8.8 \mathrm{~Hz}$, ArH-3',5'), $7.45(1 \mathrm{H}, \mathrm{s}, \mathrm{ArH}-3)$; MS m/z (\%) $521.3(\mathrm{M}+1,100), 523.2(\mathrm{M}+3,83)$.

5-[2"-Bromo-4" -(2-cyanoethyl)-6" -methoxyphenoxy]-N1'-(4'-cya-nophenyl)-4methylcarbamoylbenzene-1,2-diamine (14d)-The preparation was same as that of 6p. Starting with 14b (100 mg, $0.18 \mathrm{mmol})$, iron $(30 \mathrm{mg}, 0.54 \mathrm{mmol})$, and $\mathrm{NH}_{4} \mathrm{Cl}(95 \mathrm{mg}$, $1.82 \mathrm{mmol}$ ) to give $60 \mathrm{mg}$ of $\mathbf{1 4 d}$ : $64 \%$ yield; white solid; $\mathrm{mp} 228-230{ }^{\circ} \mathrm{C} ;{ }^{1} \mathrm{H}$ NMR $\delta 2.67$ $\left(2 \mathrm{H}, \mathrm{t}, J=6.8 \mathrm{~Hz}, \mathrm{CH}_{2} \mathrm{CN}\right), 2.94\left(2 \mathrm{H}, \mathrm{t}, J=6.8 \mathrm{~Hz}, \mathrm{ArCH}_{2}\right), 3.55\left(2 \mathrm{H}, \mathrm{br}, \mathrm{NH}_{2}\right), 3.06(3 \mathrm{H}$, d, $\left.J=4.4 \mathrm{~Hz}, \mathrm{CH}_{3}\right), 3.79\left(3 \mathrm{H}, \mathrm{s}, \mathrm{OCH}_{3}\right), 5.90(1 \mathrm{H}, \mathrm{s}, \mathrm{NH}), 6.33(1 \mathrm{H}, \mathrm{s}, \mathrm{ArH}-6), 6.74(2 \mathrm{H}, \mathrm{d}$, $\left.J=8.4 \mathrm{~Hz}, \mathrm{ArH}-2^{\prime}, 6^{\prime}\right), 6.84\left(1 \mathrm{H}, \mathrm{s}, \mathrm{ArH}-5^{\prime \prime}\right), 7.10\left(1 \mathrm{H}, \mathrm{s}, \mathrm{ArH}-3^{\prime \prime}\right), 7.43(2 \mathrm{H}, \mathrm{d}, J=8.4 \mathrm{~Hz}$, ArH-3',5'), 7.69 (1H, s, ArH-3), 7.76 (1H, d, $J=4.4 \mathrm{~Hz}, \mathrm{NH})$; MS m/z (\%) $520.2(\mathrm{M}+1$, 84), $522.2(\mathrm{M}+3,100)$.

\section{Bioassays}

Assay for Measuring the Inhibitory Activity of Compounds on HIV-1 Infection of TZM-bI Cells-Inhibition of HIV-1 infection was measured as a reduction in the level of luciferase gene expression after a single round of virus infection of TZM-bl cells as 
described previously. Briefly, 800 TCID $_{50}$ of virus (NL4-3 or drug-resistant variants) was used to infect TZM-bl cells in the presence of various concentrations of compounds. One day after infection, the culture medium was removed from each well, and $100 \mu \mathrm{L}$ of Bright Glo reagent (Promega, San Luis Obispo, CA) was added to the cells to measure luminescence using a Victor 2 luminometer. The effective concentration $\left(\mathrm{EC}_{50}\right)$ against HIV-1 strains was defined as the concentration that caused a 50\% decrease in luciferase activity (relative light units) compared to that of virus control wells.

HIV-1 Infection Assay Using MT-2 Cells-The inhibitory activity of compounds against infection by HIV-1 IIIB and its variant A17, which is resistant to multiple NNRTIs, was determined as previously described. ${ }^{30}$ Briefly, MT- 2 cells $\left(10^{4}\right.$ per well) were infected with an HIV-1 strain (100 TCID 50 ) in $200 \mu \mathrm{L}$ of RPMI 1640 containing $10 \%$ FBS in the presence or absence of a test compound at graded concentrations overnight. Then the culture supernatants were removed, and fresh media containing no test compounds were added. On the fourth day postinfection, $100 \mu \mathrm{L}$ of culture supernatants was collected from each well, mixed with equal volumes of 5\% Triton X-100, and assayed for p24 antigen, which was quantitated by an enzyme-linked immunosorbent assay, and the percentage of inhibition of p24 production was calculated as previously described. The effective concentrations for $50 \%$ inhibition $\left(\mathrm{EC}_{50}\right)$ were calculated using CalcuSyn.

Cytotoxicity Assay-A CytoTox-Glo cytotoxicity assay (Promega) was used to determine the cytotoxicity of the synthesized compounds. Parallel to the antiviral assays, TZM-bl cells were cultured in the presence of various concentrations of the compounds for 1 day. The percent of viable cells was determined by following the protocol provided by the manufacturer. The $50 \%$ cytotoxic concentration $\left(\mathrm{CC}_{50}\right)$ was defined as the concentration that caused a $50 \%$ reduction in cell viability.

\section{Molecular Modeling Studies}

Molecules 6a $\left[\mathrm{X}=\mathrm{Me} / \mathrm{Me}\right.$ and $\left.\mathrm{R}=-(\mathrm{C}=\mathrm{O}) \mathrm{NMe}_{2}\right], 14 \mathrm{~d}[\mathrm{X}=\mathrm{OMe} / \mathrm{Br} ; \mathrm{R}=-$ $(\mathrm{C}=\mathrm{O}) \mathrm{OCH}_{3}$ ], and $\mathbf{1 b}$ were sketched in $\mathrm{MOE}$ (Molecular Operating Environment, version 2011.10, Chemical Computing Group, Toronto, Canada). Conformational searches were conducted using MOE. The default parameters were applied (lowModeMD, rejection limit of 100 , iteration limit of 10000, RMS gradient of 0.005, MM iteration limit of 500, conformational limit of 10000). This process resulted in 155 conformers for $6 \mathbf{6}, 440$ conformers for 14d, and 35 conformers for $1 \mathrm{~b}$. The crystal structures of wild-type and E138K mutant HIV-1 RT in complex with 1b (PDB entry 3MEC) and nevirapine (PDB entry 2HNY), respectively, were downloaded from the RCSB Protein Data Bank for use in this modeling study. The docking tool in MOE 2011.10 was used to conduct the docking simulations. The X-ray crystal structures of $3 \mathrm{MEC}$ and $2 \mathrm{HNY}$ were adopted to represent both wild-type and mutant structures. The pocket atoms as well as residue 138 were included in the binding site model. Default docking parameters were applied. The three conformational databases for $\mathbf{6 a}, \mathbf{1 4 d}$, and $\mathbf{1 b}$ were used in the docking simulations. Poses were visually analyzed to ensure that the hydrogen bonds between the drug molecules and K101 were preserved for final analysis. The docking results of $\mathbf{1 4 d}$ are shown in Figures S1 and $\mathrm{S} 2$ of the Supporting Information. 


\section{Aqueous Solubility Determination}

Solubility was measured separately at $\mathrm{pH} 7.4$ and 2.0 by using an HPLC-UV method. Test compounds were initially dissolved in DMSO at a concentration of $10 \mathrm{mg} / \mathrm{mL}$. Ten microliters of this stock solution was spiked into either $\mathrm{pH} 7.4$ phosphate buffer $(1.0 \mathrm{~mL})$ or $0.01 \mathrm{M} \mathrm{HCl}$ (approximately $\mathrm{pH} 2.0,1.0 \mathrm{~mL}$ ) with the final DMSO concentration being $1 \%$. The mixture was stirred for $4 \mathrm{~h}$ at room temperature and then concentrated at $10000 \mathrm{rpm}$ for $5 \mathrm{~min}$. The saturated supernatants were transferred to other vials for analysis by HPLC-UV and detected at $254 \mathrm{~nm}$. Each sample was analyzed in triplicate. For quantification, a model 1200 HPLC-UV (Agilent) system was used with an Agilent Eclipse XDB-C18 column (150 $\mathrm{mm} \times 4.6 \mathrm{~mm}, 5 \mu \mathrm{m})$ and gradient elution of methanol $(\mathrm{MeOH})$ in water, starting with $60 \%$ $\mathrm{MeOH}$, which was linearly increased to $80 \%$ over $10 \mathrm{~min}$ and then slowly increased to $90 \%$ over $15 \mathrm{~min}$. The flow rate was $1.0 \mathrm{~mL} / \mathrm{min}$, and the injection volume was $15 \mu \mathrm{L}$. The aqueous concentration was determined by comparison of the peak area of the saturated solution with a standard curve plotted as peak area versus known concentrations, which were prepared by solutions of the test compound in acetonitrile (ACN) at 50, 25, 12.5, 3.13, 0.78, and $0.20 \mu \mathrm{g} / \mathrm{mL}$.

\section{Log P Measurement}

Using the same DMSO stock solution $(10 \mathrm{mg} / \mathrm{mL})$ described above, $10 \mu \mathrm{L}$ of this solution was added to n-octane $(0.6 \mathrm{~mL})$ and water $(0.6 \mathrm{~mL})$. The mixture was stirred at $\mathrm{rt}$ for $24 \mathrm{~h}$ and then left to stand overnight. Each solution $(\sim 0.2 \mathrm{~mL})$ from two phases was transferred into other vials for HPLC analysis. The instrument and conditions were the same as those for solubility determination. The $\log \mathrm{P}$ value was calculated by the peak area ratios in $\mathrm{n}$ octane and in water $\left[\log \mathrm{P}=\log \left(S_{\text {oct }} / S_{\text {water }}\right)\right]$.

\section{Microsomal Stability Assay}

DMSO stock solutions of test compounds (1-2 mg) were prepared at a concentration of 0.5 $\mathrm{mM}$ and stored at $4{ }^{\circ} \mathrm{C}$. Before the assay, a dilute solution of a test compound was prepared by adding $50 \mu \mathrm{L}$ of each DMSO stock solution to $200 \mu \mathrm{L}$ of acetonitrile to make $0.1 \mathrm{mM}$ solutions in a mixture of solvents, DMSO and acetonitrile (1:4, v/v). Human liver miscrosomes (protein content of $20 \mathrm{mg} / \mathrm{mL}, 0.5 \mathrm{~mL}$ ), $0.1 \mathrm{M}$ potassium phosphate buffer ( $\mathrm{pH}$ 7.4), and $0.5 \mathrm{M} \mathrm{MgCl}_{2}$ were mixed, and a testing compound was added to the solution. A $240 \mu \mathrm{L}$ volume of incubation solution was transferred to time $0,5,15,30$, and 45 min vials (each in duplicate wells) for warming at $37^{\circ} \mathrm{C}$ for more than $5 \mathrm{~min}$. The NADPH regenerating agent ( $5 \mathrm{mM}$ in buffer, $60 \mu \mathrm{L}$ ) was added to each vial, except the $0 \mathrm{~min}$ vial, to initiate the reaction. The incubation volume in each vial was $300 \mu \mathrm{L}$. The final concentrations of components in the incubation were $1 \mu \mathrm{M}$ test compound, $0.1 \mathrm{mg} / \mathrm{mL}$ human liver microsomes, $5 \mathrm{mM} \mathrm{MgCl}_{2}$, and $1.0 \mathrm{mM}$ NADPH with $0.1 \mathrm{M}$ potassium phosphate buffer ( $\mathrm{pH}$ 7.4). The reaction temperature was $37^{\circ} \mathrm{C}$, and the reaction was quenched by adding $600 \mu \mathrm{L}$ of icecold ACN to stop the reaction at 5, 15, 30, and $45 \mathrm{~min}$. Samples at the 0 min time point were prepared by adding $600 \mu \mathrm{L}$ of ice-cold ACN first, followed by $60 \mu \mathrm{L}$ of NADPH. Incubations of all samples were conducted in duplicate. After quenching, all samples were centrifuged at $12000 \mathrm{rpm}$ for 5 min at $4{ }^{\circ} \mathrm{C}$. A $150 \mu \mathrm{L}$ volume of supernatant was collected carefully for further LC-MS analysis. Peaks of test 
compounds at different time points were converted to percentage of remaining, and the peak values at initial time $(0 \mathrm{~min})$ served as $100 \%$. The slope of the linear regression from the log percentage remaining versus incubation time $(-k)$ was used to calculate the in vitro half-life $\left(t_{1 / 2}\right)$ as in vitro $t_{1 / 2}=0.693 / \mathrm{k}$, regarded as first-order kinetics. LC-MS analysis was conducted on an AB MDS Sciex API-3000 mass spectrometer with an electrospray ionization source (ESI). An Agilent Eclipse XDB-C18 column $(4.6 \mathrm{~mm} \times 150 \mathrm{~mm}, 5 \mu \mathrm{m})$ was used for HPLC, and $10 \mu \mathrm{L}$ of the supernatant were directly injected by an autosampler. The elution condition was $\mathrm{ACN}(80 \%)$ in water $(20 \%$ with $0.1 \% \mathrm{HCOOH})$ at a flow rate 0.5 $\mathrm{mL} / \mathrm{min}$. Electrospray ionization was operated in the positive and negative mode. The signals were detected with ESI (-) or (+) by using multiple-reaction monitoring (MRM).

\section{Determination of Predictive Physicochemical Properties}

Ligand efficiency (LE) values were calculated by normalizing the binding free energy of a

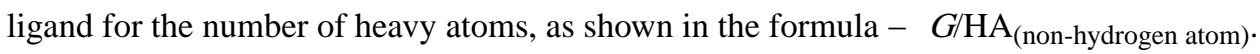
Free binding energy calculation was carried out as $\Delta G=-R T \ln K_{\mathrm{d}}$, presuming $\mathrm{EC}_{50} \approx K_{\mathrm{d}}$, a temperature of $310 \mathrm{~K}$, and given in kilocalories per heavy atom (non-hydrogen atom). The $\mathrm{pEC}_{50}$ values, negative logarithm of the molar effective concentration of a compound that causes 50\% inhibition of wild-type virus, were converted from experimental data. Lipophilic ligand efficiency (LLE) was calculated by the formula $\mathrm{pEC}_{50}-\operatorname{cog} \mathrm{D}$, in which $\operatorname{cog} \mathrm{D}$ values were calculated using ACD software. LELP was defined as the ratio of clog D and LE. The topological polar surface area (t-PSA) was calculated by using ChemDraw Ultra 12.0.

\section{X-ray Structure Deposition}

The wild-type X-ray structure was deposited in the Protein Data Bank with a resolution of $2.3 \AA$ and the mutant structure $2 \mathrm{HNY} 3 \mathrm{D}$ with $2.5 \AA$.

\section{Supplementary Material}

Refer to Web version on PubMed Central for supplementary material.

\section{Acknowledgments}

This investigation was supported by Grants 30930106 and 81120108022 from the National Natural Science Fund of China (NSFC) awarded to L. Xie and U.S. National Institutes of Health grants awarded to C.-H.C. (AI65310) and K.-H.L. (AI33066). This study was also supported in part by the National Megaprojects of China for Major Infectious Diseases (2013ZX10001-006, awarded to S.J. and L.X.) and by the Taiwan Department of Health, China Medical University Hospital Cancer Research Center of Excellence (DOH100-TD-C-111-005, awarded to K.-H.L.).

\section{ABBREVIATIONS USED}

$\mathbf{C C}_{50} \quad$ concentration that causes cytotoxicity to $50 \%$ of cells

DAAN diarylaniline

DAPA diarylpyridiamine

DAPY diary-lpyrimidine 
$\mathbf{E C}_{50}$ effective concentration that causes $50 \%$ inhibition of viral infection

HAART highly active antiretroviral therapy

HLM human liver microsome

LE ligand efficiency

LELP ligand efficiency-dependent lipophilicity

LLE lipophilic ligand efficiency

NNRTIs non-nucleoside reverse transcriptase inhibitors

SAR structure-activity relationship

SPR structure-property relationship

$\boldsymbol{t}$-PSA topological polar surface area

\section{REFERENCES}

1. Kaufmann GR, Cooper DA. Antiretroviral therapy of HIV-1 infection: established treatment strategies and new therapeutic options. Curr. Opin. Microbiol. 2000; 3:508-514. [PubMed: 11050451]

2. Das K, Clark AD Jr, Lewi PJ, Heeres J, de Jonge MR, Koymans LMH, Vinkers HM, Daeyaert F, Ludovici DW, Kukla MJ, De Corte B, Kavash RW, Ho CY, Ye H, Lichtenstein MA, Andries K, Pauwels R, de Bethune MP, Boyer PL, Clark P, Hughes SH, Janssen PAJ, Arnold E. Roles of conformational and positional adaptability in structure-based design of TMC125-R165335 (Etravirine) and related non-nucleoside reverse transcriptase inhibitors that are highly potent and effective against wild-type and drug-resistant HIV-1 variants. J. Med. Chem. 2004; 47:2550-2560. [PubMed: 15115397]

3. Janssen PAJ, Lewi PJ, Arnold E, Daeyaert F, de Jonge M, Heeres J, Koymans L, Vinkers M, Guillemont J, Pasquier E, Kukla M, Ludovici D, Andries K, de Bethune MP, Pauwels R, Das K, Clark AD, Frenkel YV, Hughes SH, Medaer B, De Knaep F, Bohets H, De Clerck F, Lampo A, Williams P, Stoffels P. In search of a novel anti-HIV drug: multidisciplinary coordination in the discovery of 4-[[4-[(1E)-2-cyanoethenyl]-2,6-dimethylphenyl]-amino]-2pyrimidinyl]amino]benzonitrile (R278474, rilpivirine). J. Med. Chem. 2005; 48:1901-1909. [PubMed: 15771434]

4. Anta L, Llibre JM, Poveda E, Blanco JL, Alvarez M, Perez-Elias MJ, Aguilera A, Caballero E, Soriano V, de Mendoza C. Rilpivirine resistance mutations in HIV patients failing non-nucleoside reverse transcriptase inhibitor-based therapies. AIDS. 2013; 27:81-85. [PubMed: 22842995]

5. Sarafianos SG, Marchand B, Das K, Himmel DM, Parniak MA, Hughes SH, Arnold E. Structure and function of HIV-1 reverse transcriptase: molecular mechanisms of polymerization and inhibition. J. Mol. Biol. 2009; 385:693-713. [PubMed: 19022262]

6. Vingerhoets J, Azijn H, Fransen E, De Baere I, Smeulders L, Jochmans D, Andries K, Pauwels R, de Bethune MP. TMC125 displays a high genetic barrier to the development of resistance: evidence from in vitro selection experiments. J. Virol. 2005; 79:12773-12782. [PubMed: 16188980]

7. Ripamonti D, Bombana E, Rizzi M. Rilpivirine: drug profile of a second-generation non-nucleoside reverse transcriptase HIV-inhibitor. Expert Rev. Anti-Infect. Ther. 2014; 12:13-29. [PubMed: 24308712]

8. Lambert-Niclot S, Charpentier C, Storto A, Fofana DB, Soulie C, Fourati S, Visseaux B, Wirden M, Morand-Joubert L, Masquelier B, Flandre P, Calvez V, Descamps D, Marcelin AG. Prevalence of reexisting resistance-associated mutations to rilpivirine, emtricitabine and tenofovir in antiretroviral- 
naive patients infected with B and non-B subtype HIV-1 viruses. J. Antimicrob. Chemother. 2013; 68:1237-1242. [PubMed: 23361642]

9. Wainberg MA. Combination therapies, effectiveness, and adherence in patients with HIV infection: clinical utility of a single tablet of emtricitabine, riplivirine, and tenofovir. HIV/AIDS. 2013; 5:149. [PubMed: 23326204]

10. Qin B, Jiang XK, Lu H, Tian XT, Barbault F, Huang L, Qian K, Chen H, Huang R, Jiang S, Lee $\mathrm{KH}, \mathrm{Xie}$ L. Diarylaniline derivatives as a distinct class of HIV-1 non-nucleoside reverse transcriptase inhibitors. J. Med. Chem. 2010; 53:4906-4916. [PubMed: 20527972]

11. Tian X, Qin B, Lu H, Lai W, Jiang S, Lee KH, Chen CH, Xie L. Discovery of diarylpyridine derivatives as novel non-nucleoside HIV-1 reverse transcriptase inhibitors. Bioorg. Med. Chem. Lett. 2009; 19:5482-5485. [PubMed: 19666220]

12. Tian X, Qin B, Wu Z, Wang X, Lu H, Morris-Natschke SL, Chen CH, Jiang S, Lee KH, Xie L. Design, synthesis, and evaluation of diarylpyridines and diarylanilines as potent non-nucleoside HIV-1 reverse transcriptase inhibitors. J. Med. Chem. 2010; 53:8287-8297. [PubMed: 21049929]

13. Sun LQ, Zhu L, Qian K, Qin B, Huang L, Chen CH, Lee KH, Xie L. Design, synthesis, and preclinical evaluations of novel 4-substituted 1,5-diarylanilines as potent HIV-1 non-nucleoside reverse transcriptase inhibitors (NNRTI) drug candidates. J. Med. Chem. 2012; 55:7219-7229. [PubMed: 22856541]

14. Wu ZY, Liu N, Qin B, Huang L, Yu F, Qian K, Morris-Natschke SL, Jiang S, Chen CH, Lee KH, Xie L. Optimization of antiviral potency and molecular properties of halogenated 2,6-diaryl pyridinamines (DAPAs) as a novel class of HIV-1 NNRTIs. ChemMedChem. 2014; 9:1546-1555. [PubMed: 24895029]

15. Bourgeois A, Womack S, Newsom D, Caldwell D. A review of rilpivirine and elvitagravir resistance features and implications for treatment sequencing. HIV Clinician. 2012; 24:1215.Rimsky L, Vingerhoets J, Van Eygen V, Eron J, Clotet B, Hoogstoel A, Boven K, Picchio G. Genotypic and phenotypic characterization of HIV-1 isolates obtained from patients on rilpivirine therapy experiencing virologic failure in the phase 3 ECHO and THRIVE studies: 48-week analysis. JAIDS, J. Acquired Immune Defic. Syndr. 2012; 59:39-46. [PubMed: 22067667]

16. Liu N, Qin B, Sun LQ, Yu F, Lu L, Jiang S, Lee KH, Xie L. Physicochemical property-driven optimization of diarylaniline compounds as potent HIV-1 non-nucleoside reverse transcriptase inhibitors. Bioorg. Med. Chem. Lett. 2014; 24:3719-3723. [PubMed: 25042339]

17. Wang R, Chen J, Qin B, Xie JW, Li H, Xie L. Metabolite profiling of two anti-HIV lead compounds in rat liver microsomes. Acta Pharmaceutica Sinica. 2012; 47:1671-1677. [PubMed: 23460975]

18. Wang R, Wei X, Chen J, Qin B, Xie JW, Li H, Xie L. Metabolite profiling of anti-HIV lead compound DAAN-4048 in rat liver microsomes. J. Int. Pharm. Res. 2013; 40:491-496.

19. De Luca L, Giacomelli G, Porcheddu A. An efficient route to alkyl chlorides from alcohols using the complex TCT/DMF. Org. Lett. 2002; 4:553-555. [PubMed: 11843589]

20. Tichenor MS, Kastrinsky DB, Boger DL. Total synthesis, structure revision, and absolute configuration of (+)-yatakemycin. J. Am. Chem. Soc. 2004; 126:8396-8398. [PubMed: 15237994]

21. Lansdon EB, Brendza KM, Hung M, Wang R, Mukund S, Jin D, Birkus G, Kutty N, Liu X. Crystal structures of HIV-1 reverse transcriptase with etravirine (TMC125) and rilpivirine (TMC278) implications for drug design. J. Med. Chem. 2010; 53:4295-4299. [PubMed: 20438081]

22. Ren J, Nichols CE, Stamp A, Chamberlain PP, Ferris R, Weaver KL, Short SA, Stammers DK. Structural insights into mechanisms of non-nucleoside drug resistance for HIV-1 reverse transcriptase mutated at codons 101 or 138. FEBS J. 2006; 273:3850-3860. [PubMed: 16911530]

23. Di L, Kerns EH, Li SQ, Petusky SL. High throughput microsomal stability assay for insoluble compounds. Int. J. Pharm. 2006; 317:54-60. [PubMed: 16621364]

24. Hopkins AL, Groom CR, Alex A. Ligand efficiency: a useful metric for lead selection. Drug Discovery Today. 2004; 9:430-431. [PubMed: 15109945]

25. Leeson PD, Springthorpe B. The influence of drug-like concepts on decision-making in medicinal chemistry. Nat. Rev. Drug Discovery. 2007; 6:881-890. [PubMed: 17971784]

26. Keseru GM, Makara GM. The influence of lead discovery strategies on the properties of drug candidates. Nat. Rev. Drug Discovery. 2009; 8:203-212. [PubMed: 19247303] 
27. Tarcsay A, Nyiri K, Keseru GM. Impact of lipophilic efficiency on compound quality. J. Med. Chem. 2012; 55:1252-1260. [PubMed: 22229549]

28. Veber DF, Johnson SR, Cheng HY, Smith BR, Ward KW, Kopple KD. Molecular properties that influence the oral bioavailability of drug candidates. J. Med. Chem. 2002; 45:2615-2623. [PubMed: 12036371]

29. Dang Z, Lai W, Qian K, Ho P, Lee KH, Chen CH, Huang L. Betulinic acid derivatives as human immunodeficiency virus type 2 (HIV-2) inhibitors. J. Med. Chem. 2009; 52:7887-7891. [PubMed: 19526990]

30. Jiang S, Lu H, Liu S, Zhao Q, He Y, Debnath AK. N-Substituted pyrrole derivatives as novel human immunodeficiency virus type 1 entry inhibitors that interfere with the gp41 six-helix bundle formation and block virus fusion. Antimicrob. Agents Chemother. 2004; 48:4349-4359. [PubMed: 15504864]

31. Chou TC, Talalay P. Quantitative analysis of dose-effect relationships: the combined effects of multiple drugs or enzyme inhibitors. Adv. Enzyme Regul. 1984; 22:27-55. [PubMed: 6382953] 

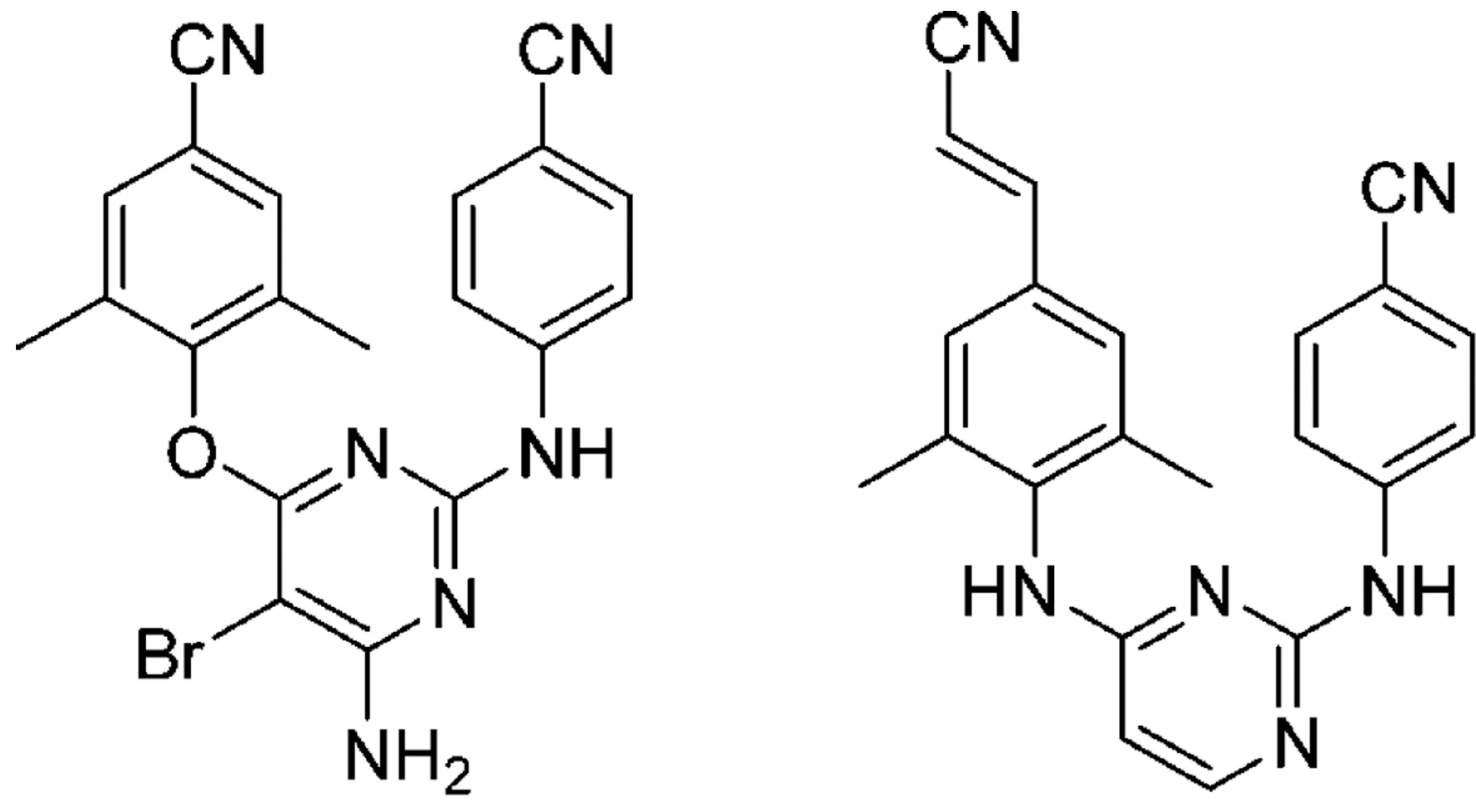

\section{Etravirine (1a)}

Rilpivirine (1b)

Figure 1.

New-generation HIV-1 NNRTI drugs approved by the U.S. FDA. 


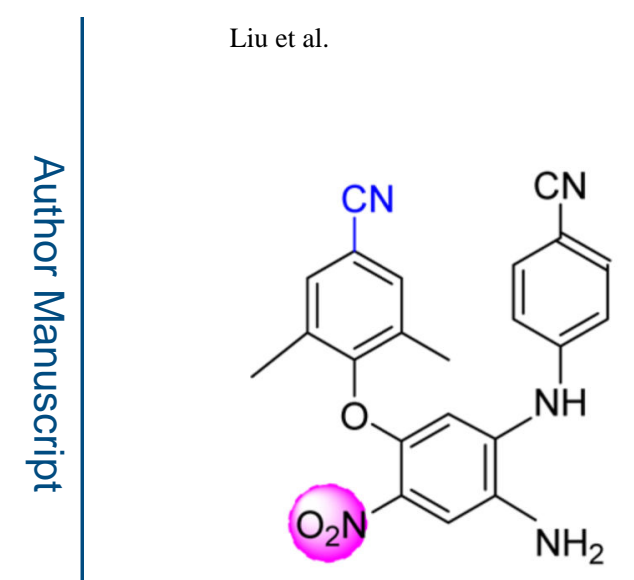

2a $E_{50} 3.0 \mathrm{nM}$ (wt)<smiles>Cc1cc(/C=C/C#N)cc(C)c1Oc1ccc(N)c(Nc2ccc(C#N)cc2)n1</smiles>

3a $\mathrm{EC}_{50} 0.71 \mathrm{nM}$ (wt)<smiles>Cc1cc(CCC#N)cc(C)c1Oc1cc(Nc2ccc(C#N)cc2)c(N)cc1-c1ccccc1O</smiles>

2b EC $500.39 \mathrm{nM}$ (wt)<smiles>COc1cc(/C=C/C#N)cc(Br)c1Oc1ccc(N)c(Nc2ccc(C#N)cc2)n1</smiles>

3b EC $503.25 \mathrm{nM}(w t)$

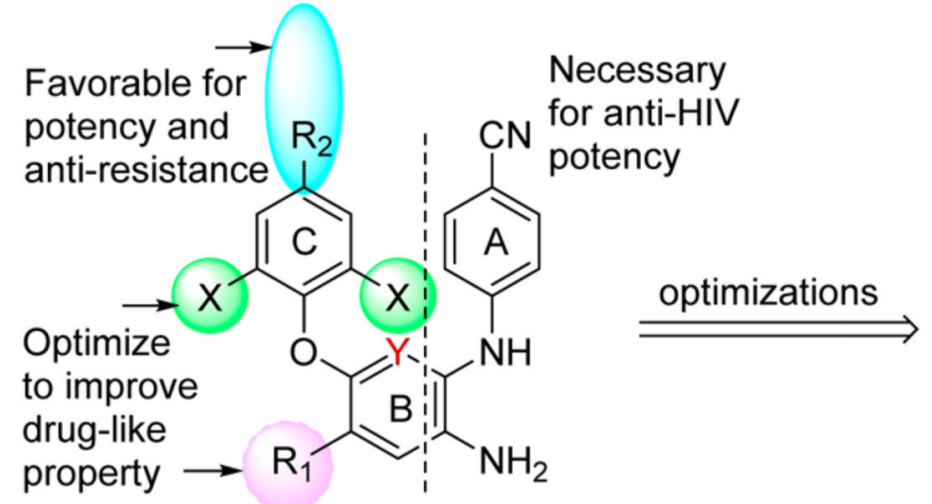

DAANs (diarylanilines): $\mathrm{Y}=\mathrm{CH}(2)$

DAPAs (diarylpyridinamines): $Y=N(3)$

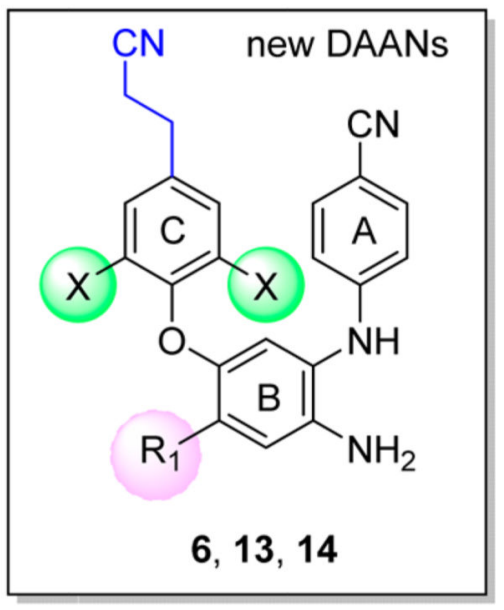

Figure 2.

Prior leads $\mathbf{2}$ and $\mathbf{3}$, known SARs, and the current lead optimization strategy. 

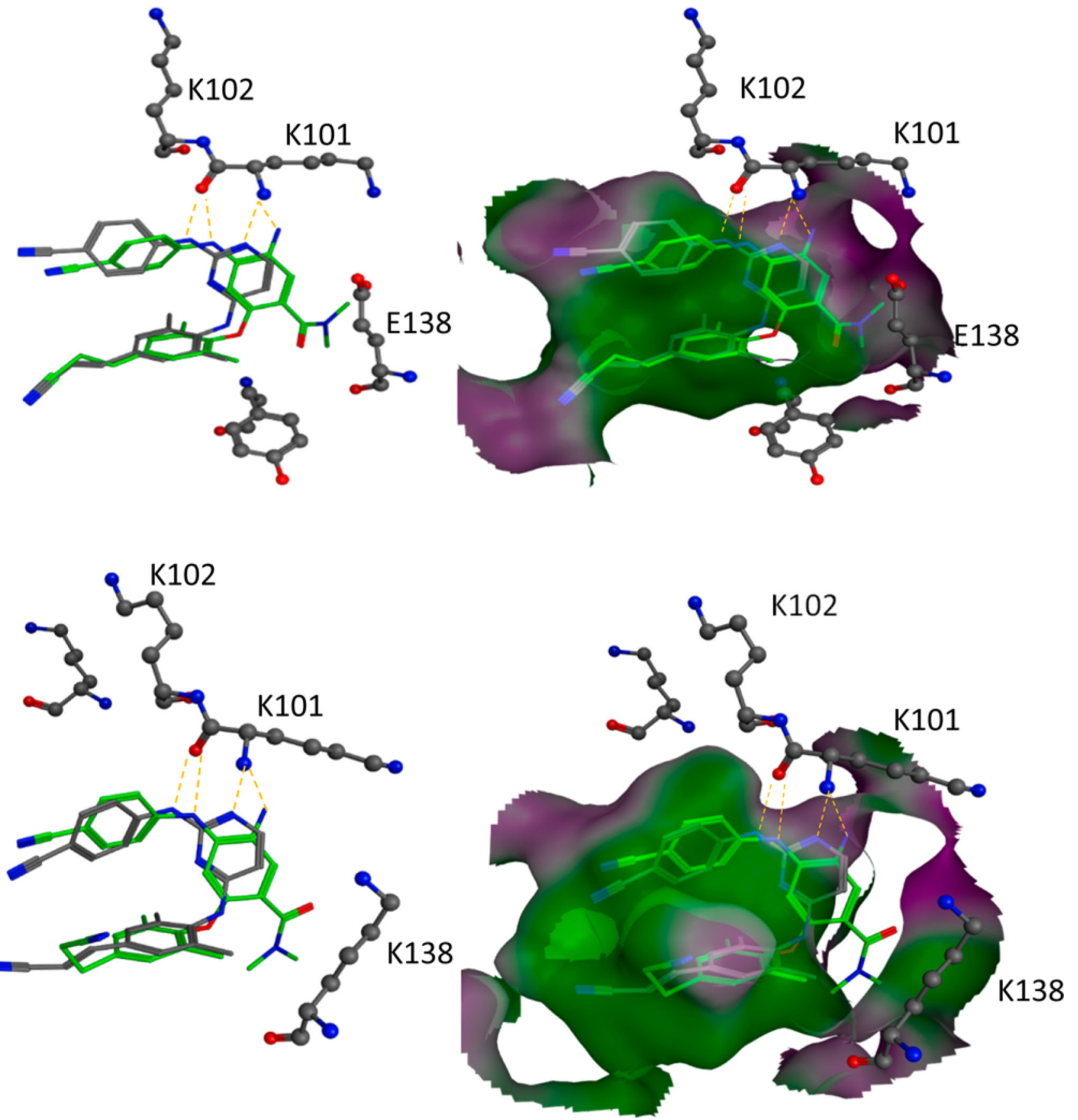

Figure 3.

Predicted binding modes of $\mathbf{6 a}$ (green sticks) and ligand $\mathbf{1 b}$ (gray sticks) with the HIV-1 RT wild-type crystal structure (3MEC) (top) and with the E138K mutant crystal structure (2HNY) (bottom), respectively, and overlapped. Both molecules $\mathbf{1 b}$ and $\mathbf{6 a}$ form two characteristic hydrogen bonds with K101 in both situations. Surrounding key amino acid side chains are shown in gray ball-and-stick format and labeled. Hydrogen bonds are shown as yellow dashed lines, and the distance between ligands and protein is $<3 \AA$. 

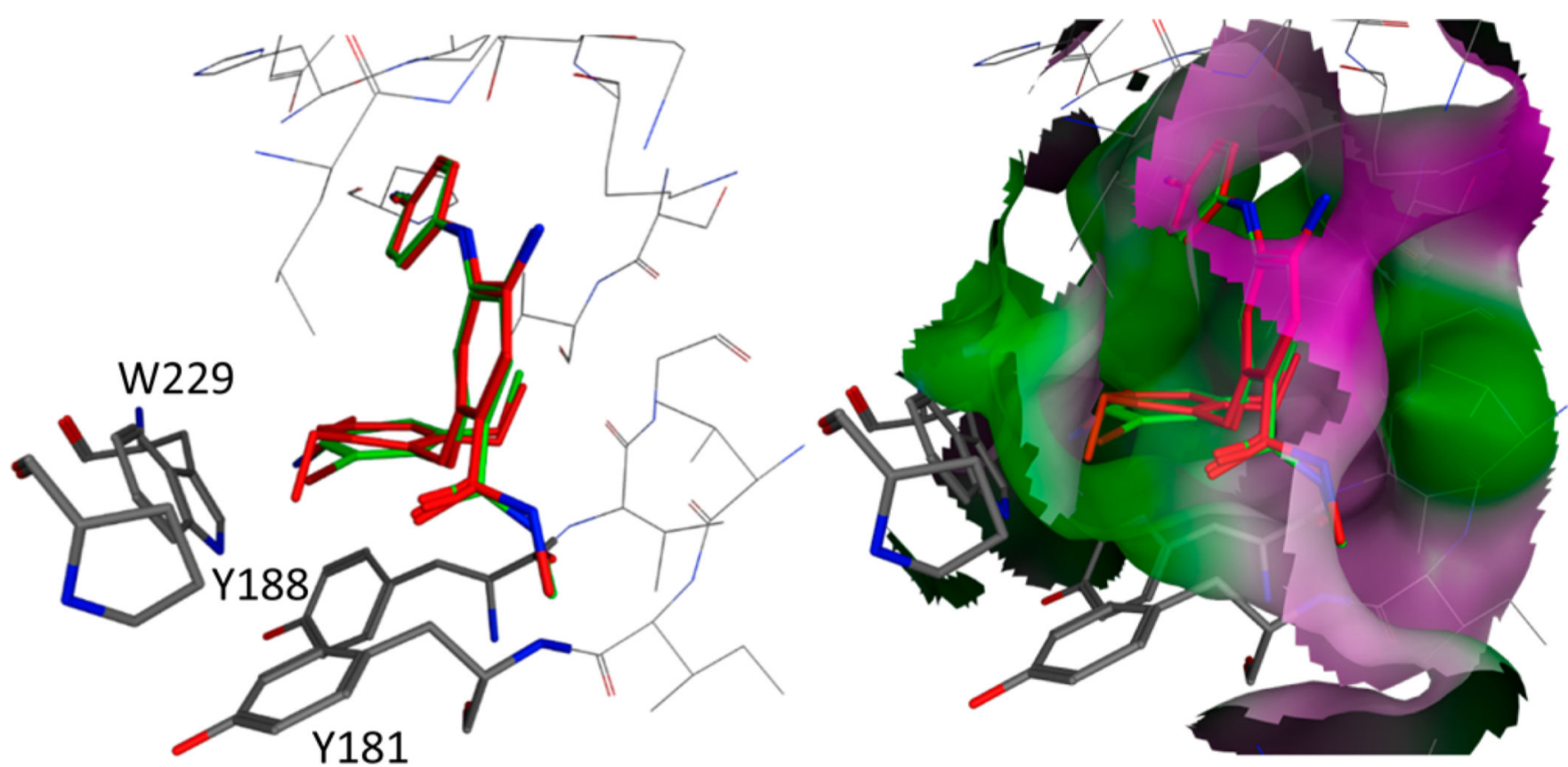

Figure 4.

Predicted and overlapped binding modes of 14d (green sticks) and 13d (red sticks) with the HIV-1 RT wild-type crystal structure (3MEC). The key amino acid side chains surrounding the $\mathrm{C}$-ring are shown in gray stick format and labeled. The distance between ligands and protein is $<3 \AA$. 
<smiles>CC(=O)c1cc([N+](=O)[O-])c(Nc2ccc(C#N)cc2)cc1Oc1c(C)cc(/C=C/C#N)cc1C</smiles><smiles>Cc1cc(/C=C/C#N)cc(C)c1Oc1cc(Nc2ccc(C#N)cc2)c([N+](=O)[O-])cc1C(=O)O</smiles><smiles>[R]NC(=O)c1cc([N+](=O)[O-])c(Nc2ccc(C#N)cc2)cc1Oc1c(C)cc(/C=C/C#CC)cc1C#N</smiles><smiles>CC#CC</smiles>

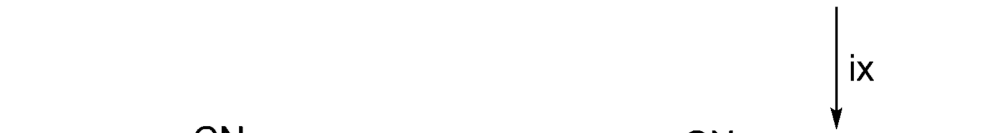<smiles>Cc1cc(/C=C/C#N)cc(C)c1Oc1cc(Nc2ccc(C#N)cc2)c([N+](=O)[O-])cc1CO</smiles><smiles></smiles>

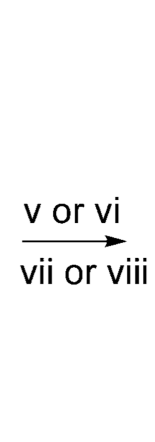

$\mathrm{R}$<smiles>[R]Cc1cc([N+](=O)[O-])c(Nc2ccc(C#N)cc2)cc1Oc1c(C)cc(/C=C/C#N)cc1C</smiles><smiles>[R]CC(C)C</smiles>

6a-c 6e-k a $\mathrm{R}^{1}=\mathrm{CONMe}_{2}$

b $\mathrm{R}^{1}=\mathrm{CONHEt}$

c $\mathrm{R}^{1}=\mathrm{CONH}$

e $\mathrm{R}^{1}=\mathrm{CH}_{2} \mathrm{NMe}_{2}$

f $\mathrm{R}^{1}=\mathrm{CH}_{2} \mathrm{NH}$

g $\mathrm{R}^{1}=\mathrm{CH}_{2} \mathrm{~N}$

h $\mathrm{R}^{1}=\mathrm{CH}_{2} \mathrm{OAc}$

i $\mathrm{R}^{1}=\mathrm{CH}_{2} \mathrm{OCO}$ j $\mathrm{R}^{1}=\mathrm{CH}_{2} \mathrm{OCONHMe}$

k $\mathrm{R}^{1}=\mathrm{CH}_{2} \mathrm{OMe}$

Scheme $1^{\mathrm{a}}$

a(i) THF/MeOH, aq $\mathrm{NaOH}$, rt, $10 \mathrm{~h}$; (ii) (a) $\mathrm{SOCl}_{2}$, reflux, $4 \mathrm{~h}$; (b) amine, THF, $0{ }^{\circ} \mathrm{C}, 0.5 \mathrm{~h}$;

(iii) $\mathrm{LiBH}_{4}, \mathrm{THF} / \mathrm{MeOH}, 0^{\circ} \mathrm{C}, 7 \mathrm{~h}$; (iv) 2,4,6-trichloro[1,3,5]triazine, $\mathrm{DMF} / \mathrm{CH}_{2} \mathrm{Cl}_{2}, \mathrm{rt}, 4 \mathrm{~h}$;

(v) amine, THF, $0{ }^{\circ} \mathrm{C}$, for $\mathbf{5 e}-\mathbf{g}$; (vi) $\mathrm{Ac}_{2} \mathrm{O}, \mathrm{NaOH}(\mathrm{s}), 100{ }^{\circ} \mathrm{C}$, microwave, $5 \mathrm{~min}$ for $\mathbf{5 h}$; (vii) acylchloride, $\mathrm{CH}_{2} \mathrm{Cl}_{2} / \mathrm{Py}$, for $\mathbf{5 i}$ and $\mathbf{5} \mathbf{j}$; (viii) $\mathrm{MeOH}, \mathrm{BiCl}_{3}$, in $\mathrm{CH}_{2} \mathrm{Cl}_{2}, \mathrm{rt}, 4 \mathrm{~h}$, for $\mathbf{5 k}$; (ix) $\mathrm{H}_{2} / \mathrm{Pd}-\mathrm{C}$, in $\mathrm{EtOH}$ or EtOAc. 


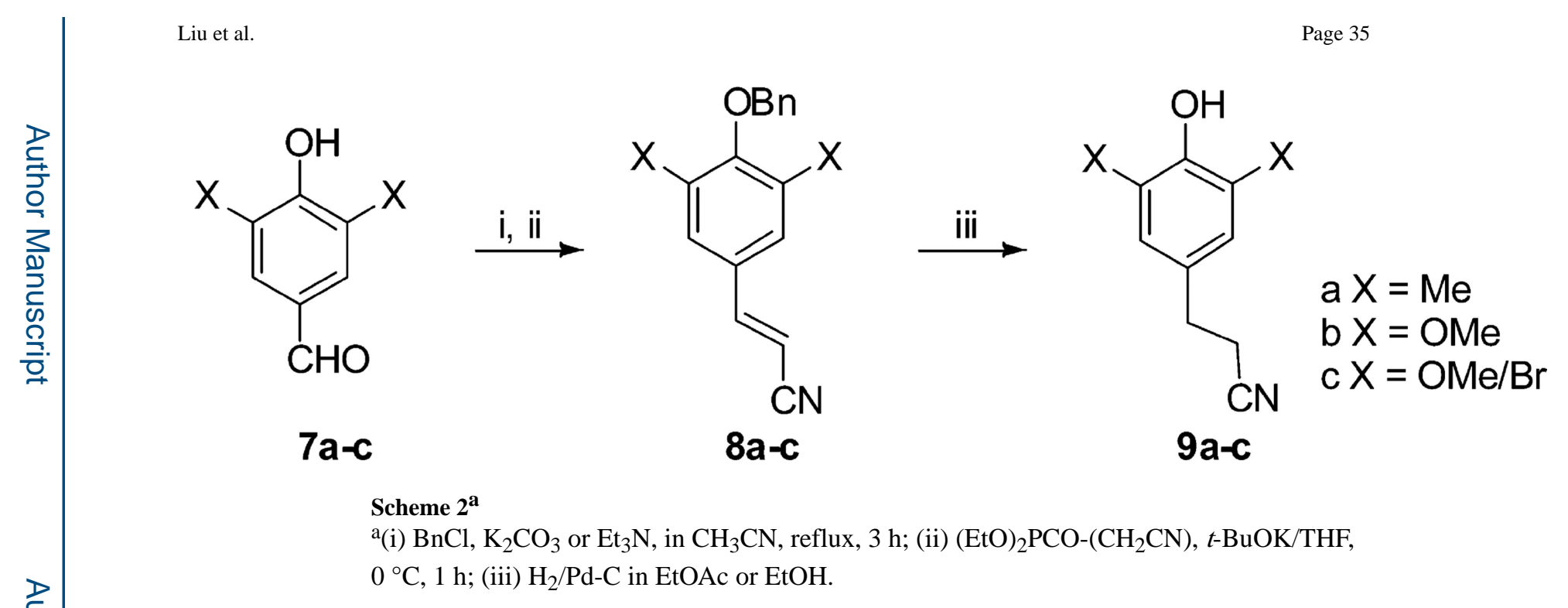




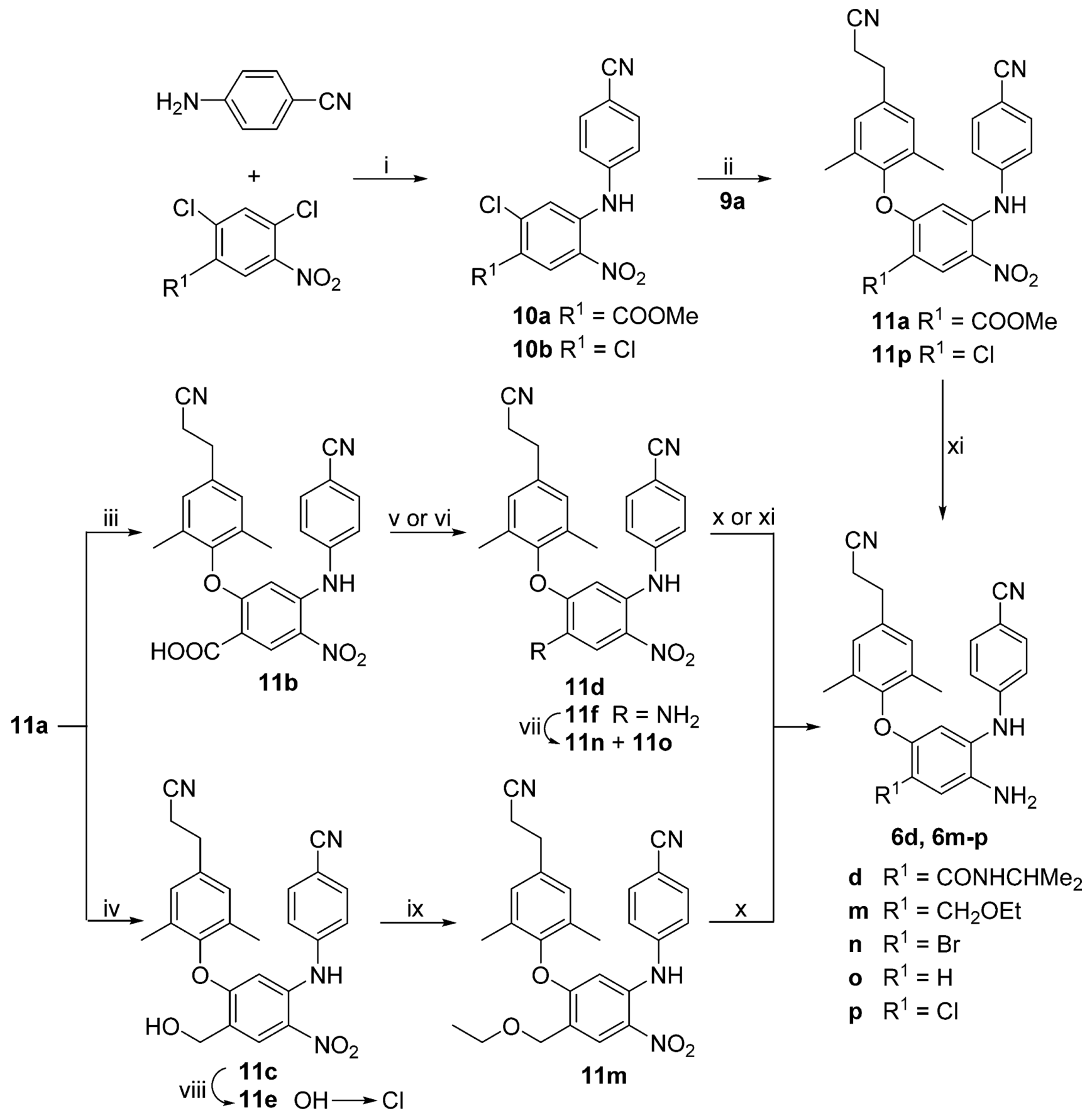

Scheme $3^{\mathbf{a}}$

a(i) $\mathrm{Cs}_{2} \mathrm{CO}_{3} / \mathrm{DMF}, 80^{\circ} \mathrm{C}$, microwave, $20 \mathrm{~min}$; (ii) $\mathrm{K}_{2} \mathrm{CO}_{3} / \mathrm{DMF}, 110{ }^{\circ} \mathrm{C}$, heating for $4 \mathrm{~h}$ or microwave, $20 \mathrm{~min}$; (iii) aq $\mathrm{NaOH}$, THF/MeOH, rt, $8 \mathrm{~h}$; (iv) $\mathrm{LiBH}_{4}$, THF/MeOH, $0{ }^{\circ} \mathrm{C}, 7 \mathrm{~h}$; (v) (a) $\mathrm{SOCl}_{2}$, reflux, $3 \mathrm{~h}$; (b) amine/THF, $0{ }^{\circ} \mathrm{C}, 0.5-1 \mathrm{~h}$; (vi) (a) DPPA/Et $3 \mathrm{~N} / \mathrm{THF}$, rt, $3 \mathrm{~h}$; (b) $\mathrm{H}_{2} \mathrm{O}$, reflux, $3 \mathrm{~h}$; (vii) (a) $\mathrm{HBr} / \mathrm{NaNO}_{3} / \mathrm{H}_{2} \mathrm{O}, 5^{\circ} \mathrm{C}, 1 \mathrm{~h}$; (b) $\mathrm{CuBr} / \mathrm{HBr}, 5^{\circ} \mathrm{C}, 3 \mathrm{~h}$; (viii) 2,4,6-trichloro[1,3,5]triazine, DMF, $\mathrm{CH}_{2} \mathrm{Cl}_{2}$, rt, $4 \mathrm{~h}$; (ix) EtOH, microwave at $100{ }^{\circ} \mathrm{C}, 20$ min; (x) $\mathrm{H}_{2} / \mathrm{Pd}-\mathrm{C}$ in EtOAc, 2-3 h, rt; (xi) $\mathrm{Fe} / \mathrm{NH}_{4} \mathrm{Cl}$, THF/MeOH/ $\mathrm{H}_{2} \mathrm{O}$, reflux, $3 \mathrm{~h}$. 


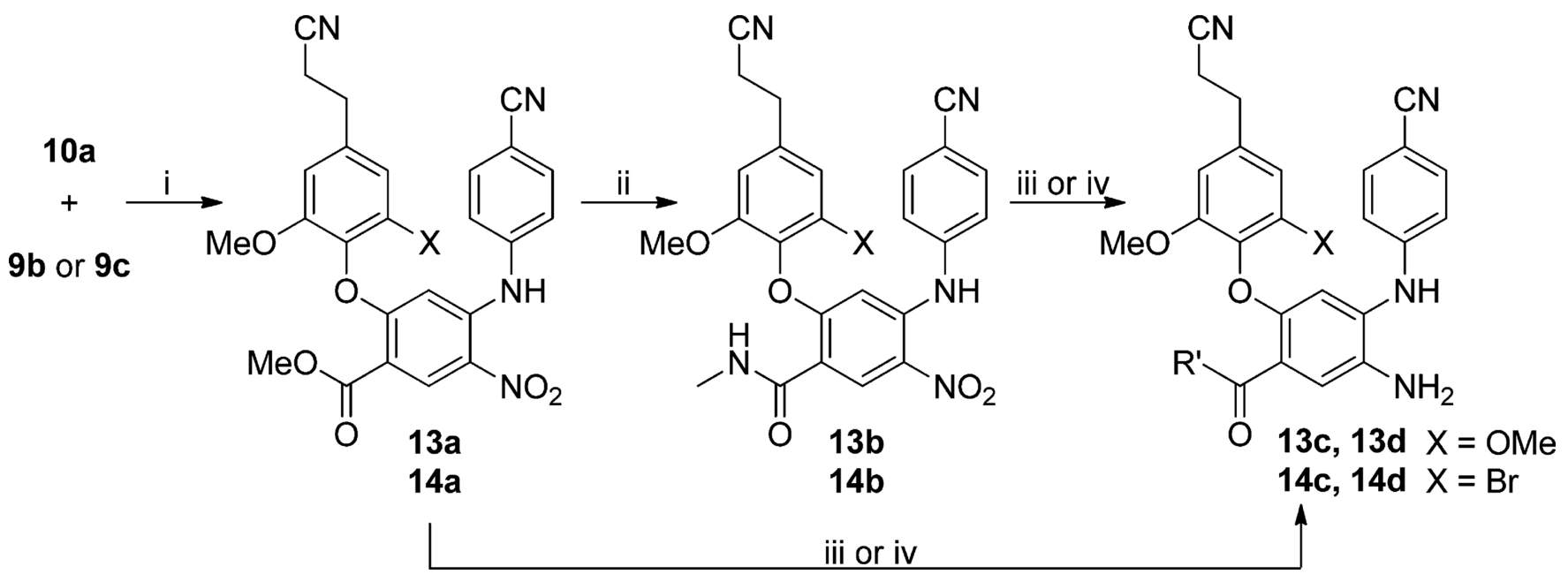

Scheme $4^{\mathrm{a}}$

a (i) $\mathrm{K}_{2} \mathrm{CO}_{3} / \mathrm{DMF}, 120{ }^{\circ} \mathrm{C}$, $4 \mathrm{~h}$; (ii) aq $\mathrm{CH}_{3} \mathrm{NH}_{2} / \mathrm{THF}, 40{ }^{\circ} \mathrm{C}$, $4 \mathrm{~h}$; (iii) $\mathrm{H}_{2} / \mathrm{Pd}-\mathrm{C}$ in EtOAc for 13; (iv) $\mathrm{Fe} / \mathrm{NH}_{4} \mathrm{Cl}$, THF/MeOH/ $\mathrm{H}_{2} \mathrm{O}$, reflux, for 14. 

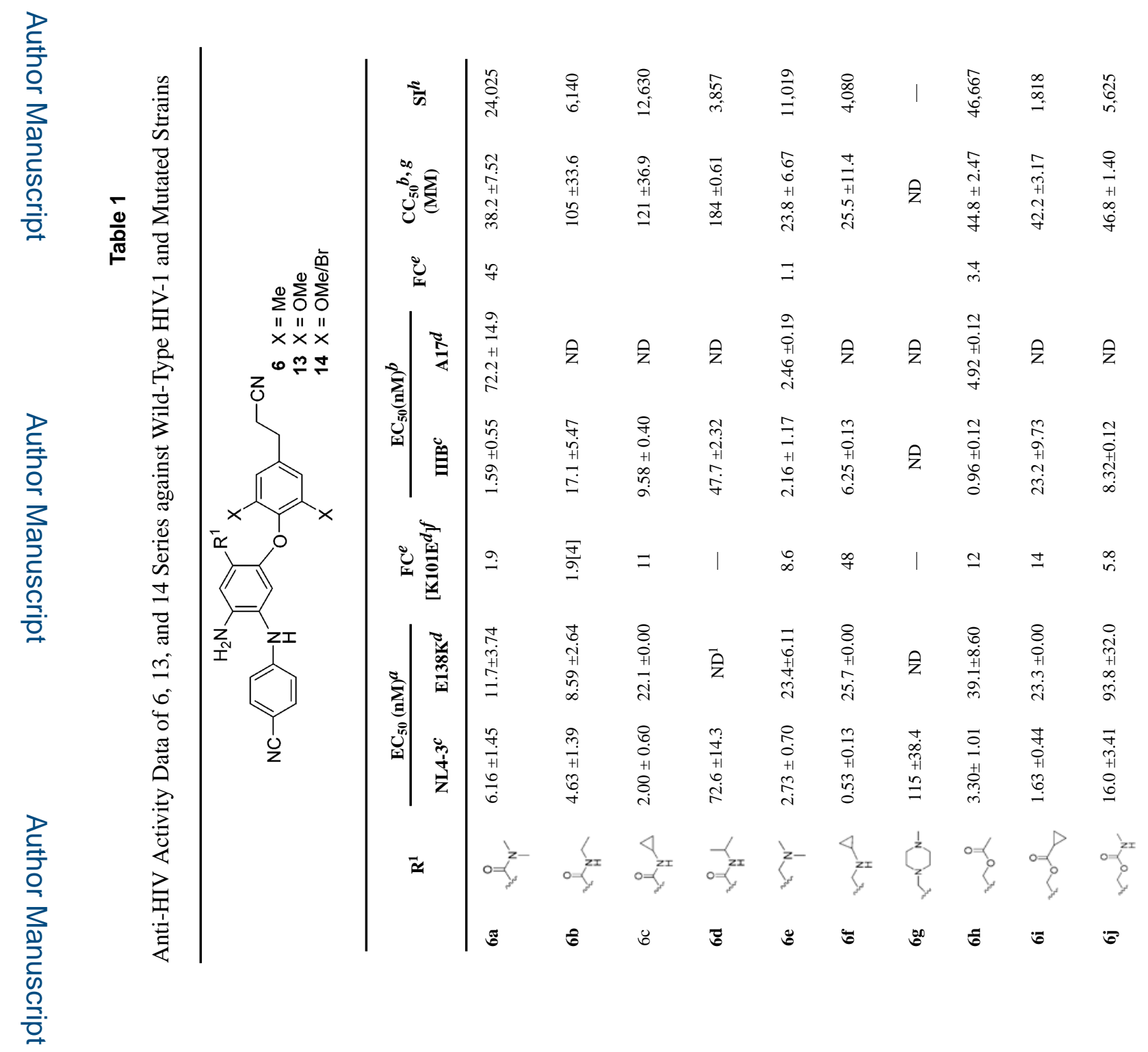

J Med Chem. Author manuscript; available in PMC 2017 April 28. 


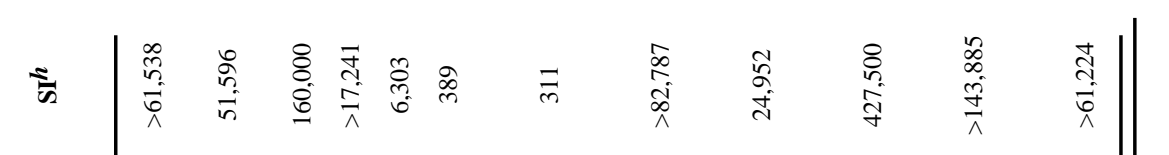

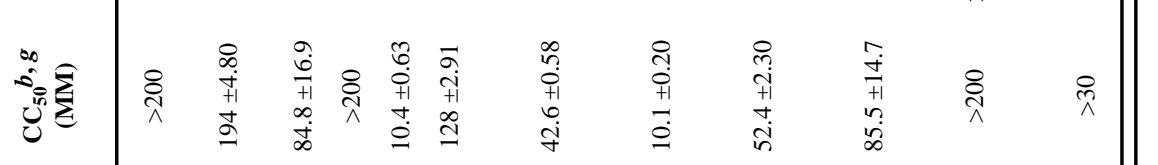




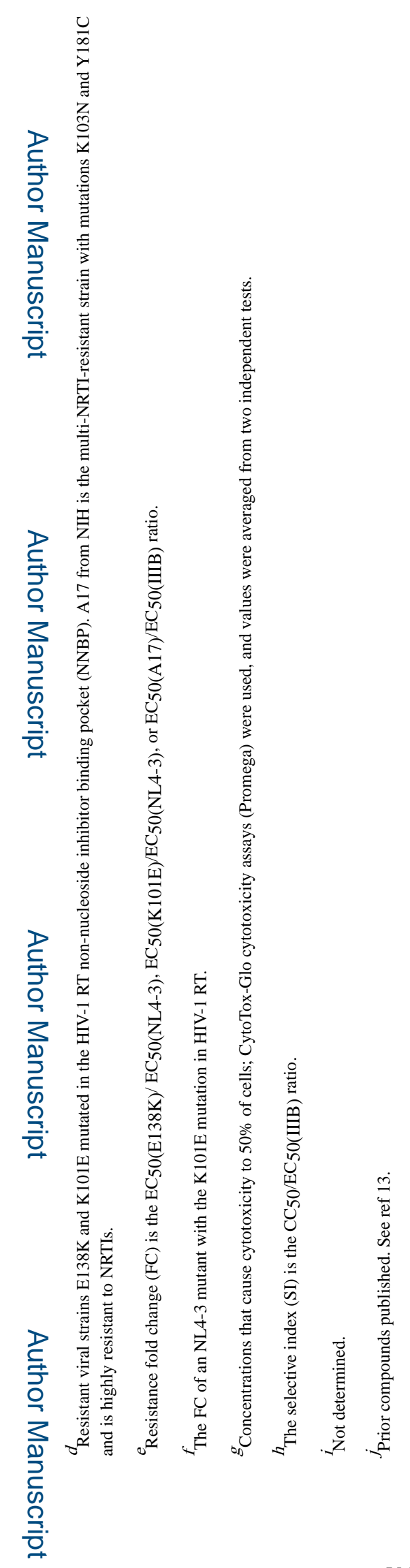

JMed Chem. Author manuscript; available in PMC 2017 April 28. 


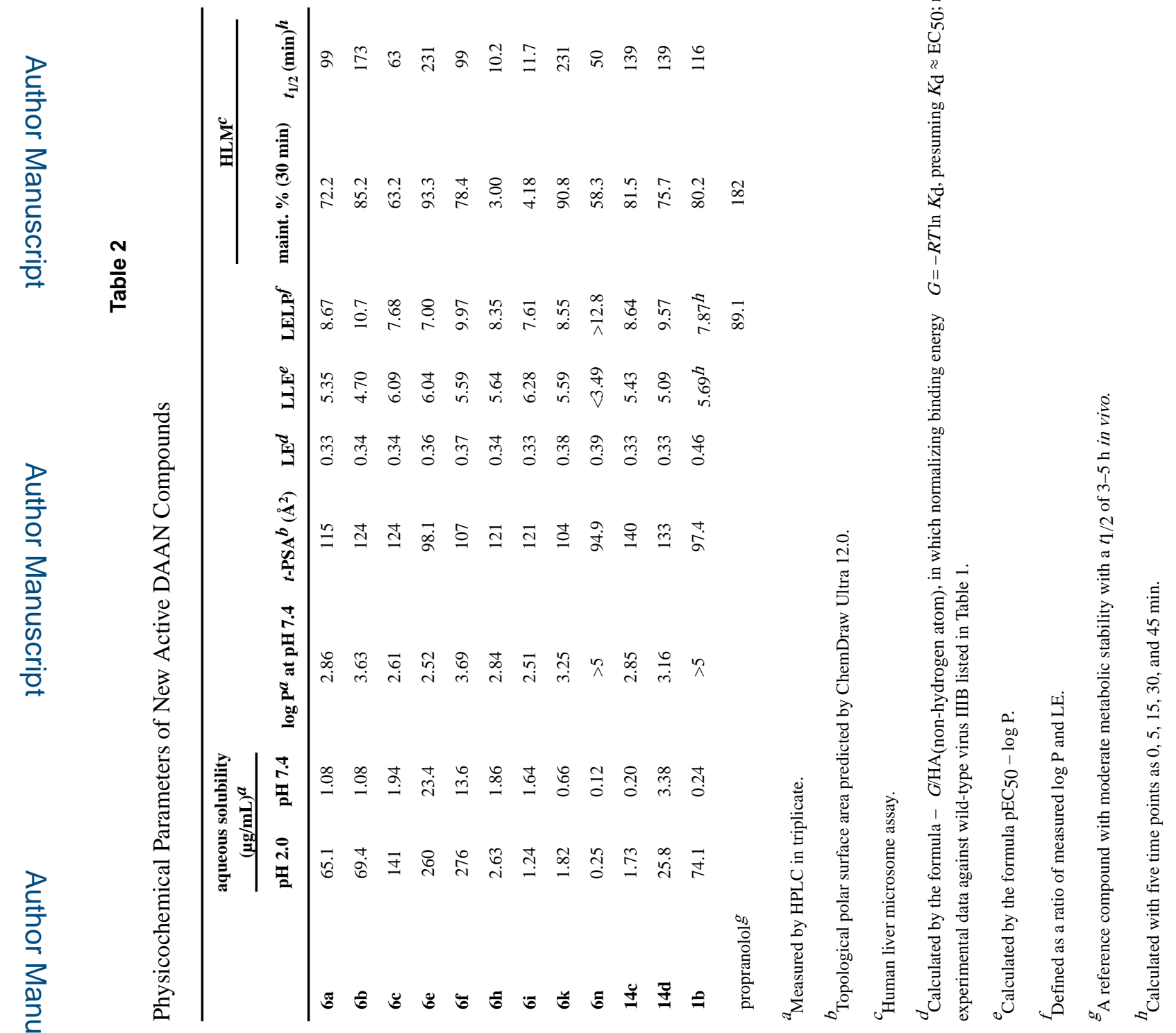

